\title{
PUBLIC ADMINISTRATION AND MANAGEMENT: CHALLENGES AND PROSPECTS
}

Collective monograph

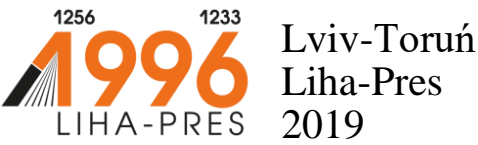




\section{Reviewers:}

Dr. Henryk Stepień, Associate Professor of the Faculty of Social and Technical Sciences, Rector's Representative for Development of Cuiavian University in Wloclawek (Republic of Poland);

Mgr. Ilona Wilińska, Chief Promotion Specialist of Promotion Department of Cuiavian University in Wloclawek (Republic of Poland).

Public administration and management: challenges and prospects : collective monograph / A. Bashtannyk, T. Bezverkhniuk, Ye. Borodin, O. Marukhlenko, etc. - Lviv-Toruń : Liha-Pres, 2019. - 192 p.

ISBN 978-966-397-162-9

Liha-Pres is an international publishing house which belongs to the category "C" according to the classification of Research School for Socio-Economic and Natural Sciences of the Environment (SENSE) [isn: 3943, 1705, 1704, 1703, 1702, 1701; prefixMetCode: 978966397]. Official website www.sense.nl. 


\section{CONTENTS}

PECULIARITIES OF REGULATION

OF ACTIVITY OF PUBLIC AUTHORITIES

IN THE CONDITIONS OF DECENTRALIZATION

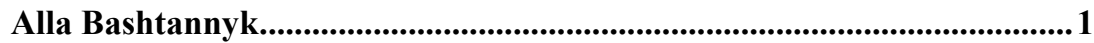

BALANCED USE OF RECREATION RESOURCES

OF THE REGION: PUBLIC-MANAGEMENT ASPECT

Tetiana Bezverkhniuk

MODEL OF PUBLIC AUTHORITIES

AT REGIONAL LEVEL IN UKRAINE: GENESIS,

STATE AND PROSPECTS OF REFORM

Yevgeniy Borodin .53

THE STRUCTURAL ANALYSIS

OF THE INVESTMENT MECHANISMS OFTHE PUBLIC POLICYINTHE SOCIAL DEVELOPMENT

Oksana Marukhlenko. .88

THE TAXATION SYSTEM OF UKRAINE:

STATE OF AFFAIRS AND PROSPECTS OF REFORMING

Dmytro Mishchenko 116

USE OF MATHEMATICAL ECONOMIC

MODELS FOR EFFECTIVE AND REASONABLE

MANAGEMENT DECISION-MAKING

TO ENFORCE THE PERFORMANCE

OF THE SOCIAL FUNCTION BY THE STATE

Viktor Ventsel

INSTITUTIONAL NATURE OF THE TAXES

AND THE FISCAL CONVERGENCE, AS A PHILOSOPHY

OF THE TAX SYSTEM PUBLIC ADMINISTRATION

Krushelnytska Taisiia. 160 
DOI https://doi.org/10.36059/978-966-397-162-9/1-31

\section{PECULIARITIES OF REGULATION OF ACTIVITY OF PUBLIC AUTHORITIES IN THE CONDITIONS OF DECENTRALIZATION}

\section{Alla Bashtannyk}

\section{INTRODUCTION}

In the conditions of decentralization of power, approaching the European principles of public administration, goals and objectives are being transformed, the main functions of public authorities are being implemented, development strategies of the Ukrainian state are being determined. The formation and development of the system of public authorities in the context of reforms requires a theoretical and methodological justification of the directions of the state, a normative definition of the functions, structure, powers of the authorities, the consolidation of an algorithm for regulating the activities of authorities. It was the decentralization of power that determined the need for the formation of fundamentally new forms and means of regulating the activities of public authorities.

The relevance of the study of mechanisms for regulating the activities of public authorities (regulatory mechanisms) is due to the fact that in modern conditions of the state it is important to form a rationally constructed model of state power that is able to implement public administration functions and ensure the provision of management services. The need to improve regulatory mechanisms is due to constitutional, administrative and judicial reforms in Ukraine, the implementation of the European integration policy, and the special conditions of the modern state. Institutional sphere requires adaptation of its own methodological content, adaptation of European experience in regulating public relations, and introducing innovative regulatory mechanisms.

The research directions of Russian scientists were addressed by the institutional aspects of regulating the activities of authorities in the 
context of transformation processes at the regional level of the state, national state and EU institutions. But they demanded an independent study of the conceptual foundations of the formation of structural characteristics and trends in the organizational development of mechanisms for regulating the activities of public authorities in the field of public administration science. The little studied directions in modern science turned out to be the principles of formation, classification, concepts and models, normative consolidation, social adaptation of regulatory mechanisms.

The purposer of the study is the theoretical and methodological substantiation of mechanisms for regulating the activities of public authorities and the development of practical recommendations for their improvement in decentralization, achieved by solving the following tasks: to analyze the nature and characteristics of the functioning of regulatory mechanisms in the public administration in the context of decentralization of power in Ukraine; highlight the properties of such mechanisms from the standpoint of public administration and administration; establish the place and role of regulatory mechanisms in the implementation of the basic tasks and functions of public administration at the national state level; to systematize modern approaches to the distribution of managerial powers between different levels of regulation under decentralization in accordance with the principles of multi-level management.

Scientific novelty lies in a comprehensive scientific study of the foundations of the formation of mechanisms for regulating the activities of public authorities, the development of practical recommendations for their improvement, which together solve important tasks of reforming public administration. On this basis, the essence, content, features and directions of improving regulatory mechanisms under decentralization are conceptually substantiated; defined the regulation and structure, legal, administrative and institutional foundations of the formation and functioning of regulatory mechanisms under the influence of internal and external factors, social factors, modern challenges in the functioning of the public administration system. 


\section{Methodological bases of the analysis of mechanisms of regulation of activity of public authorities in the field of public administration science}

In the field of public administration science, the content of the specialty "public administration mechanisms" defines theoretical and methodological substantiations of public administration mechanisms, administrative and organizational areas of the state, functions, structure, powers and characteristics of public authorities at all levels ${ }^{1}$. At the same time, the statement of the problem of scientific research of management and regulation of the activities of bodies and institutions of state power requires its own methodological support, analysis of the state power system, formalization of governance models and determination on this basis of the country's development directions. Indeed, under the conditions of decentralization of power in Ukraine, approaching the European principles of public administration, the goals and objectives of the state, the functions of public authorities, and its development strategies are being transformed.

Thus, we are talking about changing the foundations of the functioning of public administration mechanisms, supplementing the principles of regulating the activities of public authorities, the foundations of the formation of public policy, the development of a specific region (interregional complex), industry, and in the broad sense, even public spheres. That is why the mechanisms for regulating the activities of public authorities currently require their own methodological content by developing categories and concepts, laws and principles, systematizing the methods of such regulation, developing concepts and models for regulating the activities of public authorities. At the same time, it requires its own theoretical content to formalize the goals, tasks and functions of the state, its development

Averjjanov V. (2009) Ljudynocentrystsjka ideologhija jak osnova reformuvannja ukrajinsjkogho administratyvnogho prava $\mathrm{v}$ umovakh integhracijnogho procesu [Center-centered ideology as a basis for reforming Ukrainian administrative law in the context of the integration process]. Derzhava ta reghiony (Serija: Pravo), 2010, no. 2, p. 87. 
strategy as a factor in the functioning of public administration mechanisms.

It is important to note that the methodological basis of the legal aspect of the mechanism of public administration is the organizational and institutional essence of the mechanisms, the subject-object relationship of government. So, V. Averyanov defines the system of executive bodies, the essence of legal norms in such a system as the constituent elements of a mechanism, and at the same time indicates that it is through the mechanism of state administration that power is exercised $^{2}$.

G. Atamanchuk defines the mechanism of public administration as a complex system of state bodies, structured on the basis of the implementation of public administration tasks. At the same time, while studying the public administration system, G. Atamanchuk identifies such inherent characteristics of its structure: firstly, interaction within the framework of the system "management subject (state) relationships (direct and feedback) - public system"; secondly, the analysis of the system "subject of management - impact - object of management"3. Also, this researcher defines the legal status, organizational structure, system of external relations as the main features of an authority ${ }^{4}$.

In particular, on the basis of an analysis of the definitions of domestic and foreign scientists, V. Prikhodko proposed his own definition of the mechanism of public administration as a system designed for the practical implementation of public administration and

2 Averjjanov V. (2009) Ljudynocentrystsjka ideologhija jak osnova reformuvannja ukrajinsjkogho administratyvnogho prava v umovakh integhracijnogho procesu [Center-centered ideology as a basis for reforming Ukrainian administrative law in the context of the integration process]. Derzhava ta reghiony (Serija: Pravo), 2010, no. 2, p. 92.

${ }^{3}$ Atamanchuk Gh. (2005) Ghosudarstvennoe upravlenye (orghanyzacyonnofunkcyonaljnye voprosy) : ucheb. posob. Moskwa [Public Administration Theory: A Lecture Course]. Omega-L (in Russian).

${ }^{4}$ Atamanchuk Gh. (2000) Ghosudarstvennoe upravlenye (orghanyzacyonnofunkcyonaljnye voprosy): ucheb. posob. [Public administration (organizationalfunctional issue): textbook. help]. Moskwa. Legal literature (in Russian). 
the achievement of goals, which has a certain structure, methods, levers, instruments of influence on the management object with the legal, regulatory, information support. The same researcher suggests defining the mechanism of state regulation as a set of functions, stages and sequential procedures of regulatory influence on the organizational system, accompanied by the achievement of a certain result of this action, which can be compared with indicators to determine the level of achievement of the managerial (program) goals of the system ${ }^{5}$.

O. Radchenko defines the essence of the mechanism of public administration as “... a system of institutions, structures, sequential actions, forms, conditions and processes in the state as a product of organized human activity, aimed at realizing the interests and needs of people and solving pressing socio-political problems with account of state influence and regulation of public life on the basis of established social values, norms and rules; is a form of realization of the functions of the state and has as a subject government bodies ${ }^{6}$. O. Korotich proposed a new methodological approach to the structuring of the system of state governance mechanisms and government governance mechanisms, introduced the concepts of "target government governance mechanism" and "public administration process mechanism". The researcher considers the term "government control mechanism" to be the broadest concept ${ }^{7}$. Separating the approaches of O. Korotich to the classification of the mechanism of public administration as a whole, we consider it appropriate to note that the concept of mechanisms (management, regulation) in the social

5 Prykhodjko V. (2013) Mekhanizm derzhavnogho reghuljuvannja ta upravlinnja ekonomichnoju bezpekoju [The mechanism of state regulation and management of economic security]. Investyciji: praktyka ta dosvid. no. 15. pp. 6-8.

${ }^{6}$ Radchenko O. (2013) Rodovi oznaky kateghoriji mekhanizm v socialjnykh naukakh [Generic attributes of the mechanism category in the social sciences]. Publichne upravlinnja: teorija ta praktyka, № 3. pp. 19-25.

7 Korotych O. (2006) Derzhavne upravlinnja reghionaljnym rozvytkom Ukrajiny [Public Administration of Regional Development of Ukraine ] Kharkiv:. Maghistr. (in Ukrainian). 
sciences is quite broad, but the design of the "mechanism - process" looks somewhat controversial from the standpoint of characterizing public administration itself.

R. Rudnitska and O. Sidorchuk, analyzing the essence and content of public administration mechanisms, the principles of their functioning, provide definitions of the government mechanism as a quasi-system designed to achieve its goals, which has a certain structure, a set of legal norms, methods, and tools of the state impact on the control object. Moreover, the following are related to the principles of the formation of such mechanisms: determination, continuity and reliability, regularity, dynamism, consistency with the laws of control, integrity, autonomy, modeling. The authors also proposed a generalized model of public administration mechanism ${ }^{8}$. In general, agreeing with the above methodology, we believe that it is important to separate the concept of "mechanism" and "system", they differ not in formal terms (elements, components, interconnection, etc.), but primarily in terms of conceptual content.

It is worth agreeing with the methodological approach of L. Prikhodchenko on the structural-organizational and structuralfunctional determinants of the public administration mechanism ${ }^{9}$ and at the same time pay special attention to the formation and functioning of such a regulatory mechanism that has a clear algorithm for implementing the principles of public administration. Indeed, the main problem of the public administration system is the imbalance in the activities of the components of state power, the absence of socially significant regulators, the uncertainty of the characteristics of the external impact on the management system, and the incompleteness of

8 Rudnicjka R. Sydorchuk O. 2014.Sutnistj ta zmist mekhanizmiv derzhavnogho upravlinnja ta pryncypiv jikh funkcionuvannja [The essence and content of the mechanisms of public administration and principles of their functioning]. Publichne upravlinnja: teorija ta praktyka. no. 4. pp. 50-60.

Prykhodchenko L. (2008) Sutnistj ponjatj mekhanizmiv derzhavy, derzhavnogho upravlinnja ta derzhavnogho reghuljuvannja [The essence of the concepts of mechanisms of the state, public administration and state regulation]. Aktualjni problemy derzhavnogho upravlinnja: zb. nauk.pr. no 3, pp. 269-274. 
the legal design of the fundamentals of activities of the subjects of government.

A significant contribution to the development of conceptual and categorical foundations for the functioning of the mechanism of public administration was made in the works of O. Fedorchak. The author's suggestions on the classification of public administration mechanisms are based on the specific scientific method "mechanism concept public administration concept - public administration mechanism concept". At the same time, the author justifiably explains the differences in the interpretations of scientists about the mechanism of public administration and offers his own definition of the mechanism of public administration as a system designed for the practical implementation of public administration, the achievement of goals that have a certain structure, methods, levers, instruments of influence on the object of government with relevant legal, regulatory and information support. O. Fedorchak supports the position of other authors, in particular R. Rudnitsky and others, regarding the relatively complex nature of the state mechanism (the state mechanism consists of economic, motivational, organizational, political, legal mechanisms). In doing so, the researcher presents her own generalized classification of the mechanism of public administration by distinguishing mechanisms by functional purpose and by management ${ }^{10}$. In our opinion, such a classification is more acceptable in the sense of the category of public administration, and O. Fedorchak developed model of organizational management mechanism in the regional state administration can serve as a basis for developing an integrated model of multi-level management, provided that the region (region) is defined as the basic level of formation of the state mechanism. management.

${ }^{10}$ Fedorchak O. (2008) Klasyfikacija mekhanizmiv derzhavnogho upravlinnja [Classification of mechanisms of public administration]. Demokratychne vrjaduvannja: Naukov. visnyk LRIDU NADU. [Democratic Governance: Scientific. Bulletin of LRIDU NADU] vol. 1. Retrieved from: www.lvivacademy.com_O_Fedorchak.pdf. Accessed (5.11.2019). 
In this format of the perception of regulatory mechanisms, it is important to indicate the general format proposed by V. Kniazev and V. Bakumenko for defining the mechanism of public administration as “... practical measures, means, incentive levers with which public authorities influence society, production, any social a system to achieve your goals" ". Most domestic researchers propose a generalized concept of a "comprehensive mechanism" as a combination of economic, social, organizational, political, legal and other means of influence of public authorities on public relations. At the same time, such a definition is expedient and justifiable also applicable to the regulatory mechanism, since the components of the public administration mechanism are presented precisely because of the regulatory influence of the subject of management. In addition, one should take into account the justified approach of N. Nyzhnyk and A. Mashkova to determine the mechanism of public administration as an integral part of the management system, which provides an impact on factors on the state of which the result of the activity of the administrative object depends ${ }^{12}$. In our opinion, any impact (first of all, subject-object impact) in the government system is determined by the modern paradigm of social regulation, and accordingly it is important to determine the positive dichotomy "governance mechanisms - regulatory mechanisms" in the public administration system.

From the standpoint of the methodology of public administration, it is advisable to determine the characteristics of regulatory mechanisms through the characteristics of the activities of state authorities, in particular, the legal status, structure, interaction with other authorities, determining the influence of the external environment on the regulatory object and subject. Formally, at present,

${ }^{11}$ Knjazjev V., Bakumenko V. (2002) Derzhavne upravlinnja: slovn.-dovidn. [Public administration: vocabulary reference]. Kyiv: UADU. (in Ukraine).

12 Nyzhnyk N. (1998) Systemnyj pidkhid v orghanizaciji derzhavnogho upravlinnja: navch. posib. [Systematic Approach in Public Administration: Tutorial]. Kyiv: UADU. (in Ukraine) 
there are several strategic directions of research in the context of the concept of "public administration mechanism". Firstly, an intheoretical study of public administration mechanisms in a specific sector of the economy. Secondly, studies of the directions and principles of the formation and implementation of state policy in a particular sphere (or industry), providing for the analysis of the emergence, formation and development of integrated regulatory mechanisms as a combination of territorial, sectoral and intersectoral regulation. Thirdly, studies of formally defined mechanisms of state regulation of the development of a country, a region of an industry, programs and mechanisms for their implementation. Fourth, a comprehensive analysis of the functioning of the systems and structures of public authorities (status, goals, objectives, functions, resources), the formation on the basis of such an analysis of the functional regulatory mechanisms. Fifth, research on targeted, organizational, resource and other components of the regulatory process. Sixth, the functioning of regulatory mechanisms at the central, regional and local levels in accordance with the principles of multilevel management. Seventh, an analysis of the institutional economic, legal, social, historical foundations of the functioning of such mechanisms.

For a long time in the scientific community there has been a constant discussion about the distinction between the concepts of "public administration mechanisms" and "state regulation mechanisms", an interpretation of the essence of regulation as a social phenomenon and manifestations of social impact ${ }^{13}$. In particular, revealing the importance of organizational and legal support for the implementation of administrative reform for improving the activities of authorities, the role of the legislative and legislative aspects of the

13 Bashtannyk A. (2015) Konceptualjni zasady naukovogho analizu stanovlennja mekhanizmiv reghuljuvannja dijaljnosti orghaniv vlady $\mathrm{v}$ Ukrajini [Conceptual bases of the scientifically developed structure of regulation of power activity in Ukraine]. Efektyvnistj derzhavnogho upravlinnja: zb. nauk. pr. no. 43. pp. 281-286. 
formation of regulatory mechanisms, it should be pointed out that among the main problems that impede the implementation of reforms is its legislative support, which leads to fragmentation, the gap between the regulatory processes of administrative reform and the processes of whelp organizational measures declared objectives.

At the same time, systematization of mechanisms, forms, structure, approaches and tools for regulating the activities of authorities aimed at implementing such managerial tasks remains unresolved:

1) the need to maintain the highly effective functioning of regulatory mechanisms in the legislative, executive and judicial systems at the central, regional, subregional and local levels of government;

2) the need to form a modern effective system of local selfgovernment; the need to introduce the ideology of the functioning of executive bodies, local self-government as activities to ensure and realize the rights and freedoms of citizens, the provision of state and public services;

3 ) the creation of a modern system of training and retraining of managerial personnel in order to ensure the quality of the functioning of mechanisms for regulating the activities of public authorities in the field of public administration science;

4) improving the legal framework for the implementation of administrative reform, primarily in the format of rationalizing mechanisms for regulating the activities of authorities, etc.

We believe that the category of "mechanisms of state regulation" was studied in the science of public administration mainly from the perspective of a functional approach, within which the basis of the research is the objective-targeted approach, and in fact, government regulation acts as a specific concept with respect to public administration as a generic concept.

The existing definitions of "government regulation" are formulated in the context of specific areas of application, based on an 
industry approach ${ }^{14}$. In this context, it is necessary to highlight the modern research problem associated with the transfer of the industry aspect of the concept of regulation (state regulation, regulation mechanism, etc.) in the general methodological context. So, for example, A. Komyakovim, "the mechanism of state regulation should be considered as a set of organizational and economic methods and tools with which interrelated functions are performed to ensure continuous, effective action in harmonizing the system (state) to increase the functioning of the economy"15.

Accordingly, the basic concept of the theoretical and methodological foundations for the development and functioning of public administration mechanisms is the "regulation" category, which is the main area of research for the specialty 25.00 .02 - public administration mechanisms ${ }^{16}$ (despite the fact that the specialty passport provides for only three blocks: 1) state regulation of the development of a country, region, industry, programs and mechanisms for their implementation; 2) mechanisms of state regulation of individual sectors and spheres of public life and their improvement; 3) management and regulation of the activities of bodies and institutions of state power: analysis, modeling and optimization ${ }^{17}$. In a combination of research areas of government regulation mechanisms, it is important to identify research areas that formed the basis for the formation of the modern methodological resource of public

14 Meljnychenko V. (2004) Decentralizacija ta dekoncentracija publichnoji vlady na postradjansjkomu prostori: determinovanistj, znachennja, mezhi [Decentralization and deconcentration of public power in the post-soviet space: determination, meaning, limits ]. Visnyk Khmeljnycjkogho instytutu reghionaljnogho upravlinnja ta prava, no 1-2, pp. 282-288.

${ }^{15}$ Kom'jakov O. (2000) Derzhavne reghuljuvannja perekhidnoji ekonomiky [State control in a transition period economy] (PhD Thesis): Kyiv: Kyiv National Economic University.

16 Higher Attestation Commission (2007) Passports of specialties. HAC Bulletin of Ukraine. no 3. pp. 4-8.

${ }^{17}$ Bakumenko V. (2014) Pidkhid do vyznachennja pasportiv specialjnostej shljakhom systemnogho analizu derzhavnogho upravlinnja [An approach to the definition of specialty passports through a systematic analysis of public administration]. Aspekty publichnogho upravlinnja, no 3-4, pp. 5-9. 
administration science. At the same time, we are the main criterion for the distribution of works of domestic scientists a specific subject and object of study of a particular scientist:

1) public administration at the industry level;

2) industry aspect of the formation of mechanisms of state regulation

3) mechanisms of state regulation of the development of the state, region;

4) state management of regional development (management at the regional level);

5) mechanisms for regulating the activities of authorities in certain areas.

In particular, A. Merzliak proved that one of the most important effective mechanisms of socio-economic transformation is the activation of the investment process by attracting foreign investment. A. Merzliak points out that it is impossible to achieve positive results without defining the investment mechanism of market entities at the macro, meso and micro levels, and notes that investment policy is considered as the most important component of the general economic policy pursued by the state. In addition, it is important to agree with the conceptual approach of A. Merzliak on the role of the European integration vector for Ukraine, the introduction of experience in implementing state policy of the states of the East European space, some of which are related to post-Soviet ones, which leads to similarities in the level of economic development and the problems, goals and objectives facing them ${ }^{18}$. In our opinion, the mechanisms of regulating the activities of state authorities should be understood as the internal structural unity of institutional, organizational, legal and

18 Merzljak A., Scryabina D. (2015) Derzhavna polityka skhidnojevropejsjkykh krajin u sferi jevrointeghraciji:perspektyvy adaptaciji dlja Ukrajiny [State Policy of Eastern European Countries in the Field of European Integration: Adaptation Prospects for Ukraine] Teorija ta praktyka derzhavnogho upravlinnja ta miscevogho samovrjaduvannja [The theory and practice of public administration and local self-government] (electronic journal), no. 1. Retrieved from: http://el-zbirn-du.at.ua/2015_1/13.pdf. Accessed (5.11.2019). 
administrative means, forms and methods in the state administration system, a rational combination of which on the basis of a systematic approach allows you to change the usual regulation of the behavior of objects and subjects of management objects on the regulatory impact of the subject regarding social relations.

The given model allows us to characterize the regulatory mechanisms from the standpoint of:

1) semantic context - the definition of a mechanism as: a system; complex; totality; structural unity and on this basis the wording of the author's definition of the mechanism for regulating the activities of public authorities;

2) a functional context - the definition of a mechanism through a comprehensive analysis of means, forms, methods, functional features, implementation tools, management algorithms and, on this basis, the development of directions for streamlining the activities of state authorities;

3) institutional context - the definition of subjects, objects and objectives of regulation and, on this basis, the development of the format of an integrated regulatory mechanism;

4) the administrative context - the definition of the essence of the regulatory impact in the system of public authorities, the formulation on this basis of the conceptual framework for the functioning of regulatory mechanisms in decentralization.

So, the methodology for studying the process of formation and development of public administration mechanisms, and accordingly the mechanisms for regulating the activities of public authorities, should be based on an integrative combination of the political and legal foundations of the functioning of public authorities, the institutional features of the functioning of public administration mechanisms, the establishment of organizational characteristics of subjects and regulatory objects authorities, analysis of administrative procedures how about new regulation. From these positions, it is important, first of all, to focus on ensuring the needs of the subjects and objects of management in the regulatory impact, which should be fixed by the principles of regulation and special regulations containing individualized (specific) 
characteristics of regulation. Moreover, the general structure of the study of the mechanism for regulating the activities of public authorities requires the solution of such research problems:

- the development of theoretical and methodological foundations for the development of mechanisms for managing the activities of authorities at different levels within the national state, the identification of historical trends in the formation of the political and legal framework for regulating power relations in Ukraine as an independent direction of the science of public administration;

- systematization of the European experience of rationalizing regulatory mechanisms through the use of modern methodology of scientific research, based on the principles of multi-level management, complementarity of the components of the state (public administration) system;

- clarification and addition of the conceptual and categorical apparatus regarding the activities of subjects of public relations in the field of regulation of public authorities through the tasks, goals, principles, competencies of political institutions, as well as finding out the place of authorities in complex administrative systems;

- development of the conceptual foundations of the formation of an innovative regulatory mechanism that meets modern concepts of "Good governance" and "New public management".

In the context of the "reset of power" process, it is important to determine the key characteristic of the regulatory mechanism itself the stability of such regulation, the principles and principles of regulation, the continuity of constitutional norms that determine the status of subjects of regulation of the activities of state authorities. At the same time, the process of reforming public administration should be determined by research: firstly, both the predicted and the spontaneous factors (regulators) of internal and external impacts on social relations stabilize the country's political system; secondly, the organizational means of improving the management system at the level of the national state, if the individual criteria of social reforms are not known in advance, are formed under the influence of changes in the political course and act as an element of rationalization of public 
authority. So, formally we are talking about the search for such a socially significant regulator that will be able to clearly determine the necessary direction of development of the public administration system in the new political conditions, and at the same time maintain a certain continuity of the country's political course. In this context, the question arises about the essence of modern reform of public administration as a certain imperative of public policy in an integrated form, which determines, in fact, the vector of reforms.

Under such conditions, changes have taken place in the modern concept of the activity of authorities, including through the implementation of the European principles of public administration in accordance with the concepts of "New public management" and "Good governance". After all, the modern European principles of public administration, the universally recognized democratic values of European civilization (rule of law, democracy, human rights) ${ }^{19}$ serve as a guideline for the implementation of public administration reforms, determine the essence of modernization of public administration in the political and administrative sense by creating innovative regulatory mechanisms in public administration system. At the same time, the construction of innovative regulatory mechanisms provides for the determination of the historical foundations of the formation of such mechanisms. The application of the historical method in the study is due not only to the advisability of developing an accurate periodization of the formation of management mechanisms in Ukraine, but also to updating the determination of specific (special) conditions for the functioning of regulatory mechanisms at a particular historical stage, establishing patterns and trends in the development of mechanisms at the national and regional levels, and determining at this the basis of priority directions of the state.

${ }^{19}$ Shevchuk B. (2012) Jevropejsjki pryncypy nalezhnogho vrjaduvannja ta reforma systemy orghaniv vykonavchoji vlady v Ukrajini [European principles of good governance and reform of the executive power system in Ukraine]. Demokratychne vrjaduvannja. [Demokratychne vrjaduvannja] (electronic journal), no. 9. Rezhym from: http://www.lvivacademy.com/visnik9/fail/Shevchuk_B.pdf. Accessed (5.11.2019). 
The modern methodology for studying regulatory mechanisms also provides for the use of a comparative analysis of the activities of authorities in Ukraine and foreign countries. Such an analysis is based on the principles of the innovation paradigm of public administration: a combination of constitutionally established procedures for public administration and the components of social management; development of democratic principles of state regulation, institutionalization of public influence on the adoption of public management decisions in the development of public policy; objectivity, accessibility, completeness and efficiency of information; rational organization of the management apparatus; development planning and forecasting; conducting personnel policies in government based on the principles of professionalism; guarantee of legality and control over the implementation and compliance with laws. It should be noted that such an innovative paradigm proceeds from the modern interpretation of public administration as an integrative combination of managerial activity of public servants and persons holding political positions, institutional unity of structure and procedures in the system of public authorities. Public administration includes activities that ensure the effective functioning of the entire system of public authorities and local authorities and provide for the wide involvement of various stakeholders in the development and implementation of public policy. The conceptual diagram of the study of the functioning of the regulatory mechanism is presented in Fig. 1.

The given conceptual scheme reflects the regulation algorithm based on optimization criteria in complex administrative systems. Indeed, in the conditions of the transformational development of Ukraine, the urgent problem of the science of public administration is the development of conceptual provisions for the implementation of the foundations of public administration, the meaning of which is to create an effective system of government by providing guaranteed protection and harmonious socially-oriented development of the governance system and the totality of public relations. This requires ensuring the possibility and ability of public administration entities to form capable regulatory mechanisms at all levels of the territorial 
organization of the state. At the same time, integrated mechanisms for regulating the activities of state authorities (as a result of modern administrative reform) should function even with unfavorable options for the development of internal and external processes.

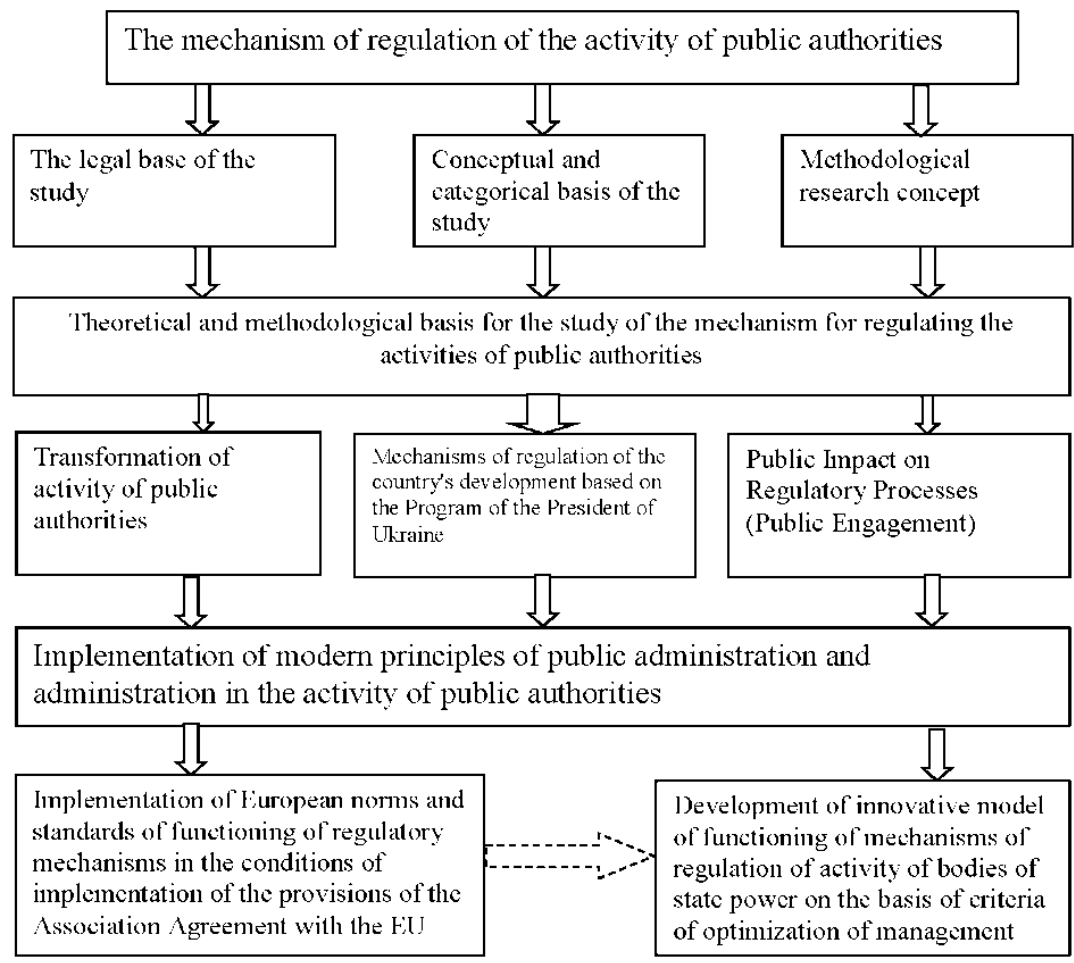

\section{Fig. 1. The conceptual scheme of the study of the functioning of the regulatory mechanism}

It should be noted that the mechanism for regulating the activities of public authorities is characterized by the presence of a set of interconnected components of a theoretical, methodological, organizational and institutional nature. The construction of a democratic, rule-of-law state requires the formation of appropriate scientific support for the implementation of reforms, initially based on advanced research models to improve public administration. 


\section{The conceptual framework for the functioning of mechanisms for regulating the activities of public authorities in Ukraine in decentralization}

The democratic transformations taking place in Ukraine, the intensification of the processes of formation of civil society institutions and the building of a democratic, social, legal state require the optimal combination of political, social, economic, cultural trends in modernizing modern Ukrainian society and effectively improving the mechanism of state power.

The formation of a sovereign, independent, democratic, social, legal state in Ukraine (Article 1 of the Constitution of Ukraine) objectively updated not only the principle of separation of powers, but also served as the normative basis for the scientific and pragmatic legalization of state power and local self-government (Article 5 of the Constitution of Ukraine). The institutional change of any element in the system of state power leads to the transformation of the entire system of power relations and contributes to the formation of a fundamentally new regulatory mechanism.

The system of public authorities includes structural changes in regulatory mechanisms from the standpoint of institutional regulation of the activities of authorities in combination with organizational changes and the adoption of internal regulations. From the perspective of historical analysis, it is necessary to define the concept of the state as a sovereign administrative-territorial organization of politically institutionalized power, within the framework of which there is formed: a functional administrative apparatus, an effective enforcement apparatus, a rational law-making mechanism and law enforcement aimed at the implementation of state power at all levels of government. Moreover, the mechanism of the state acts as a structurally integrated set of components of the state power system.

That is why the primary task of studying regulatory mechanisms is to determine the structure and characteristics of the activities of state authorities at all levels. The public authority is a functionally, organizationally and structurally autonomous element of the state apparatus (national government management mechanism), is endowed 
with a legislatively established set of powers (direct and delegated) in accordance with the intended purpose, consists of structural units and posts that hold public servants, and is referred to by the Constitution of Ukraine and the laws of Ukraine in the system of public authorities. This is the functional feature of a public authority: this is created with the goal of directly implementing a specific type of government activity; performs activities characterized by a clearly defined state orientation, goals, tasks and functions, a certain amount of competence (rights and obligations); carries out its activities using methods and forms defined by the state; has a certain legal form, internal structure and external relations.

Classification of types of government bodies is carried out according to various criteria: according to the criterion of legal level higher, central, local; by the nature of competence (content of functions) general, sectoral, functional or mixed competence; in terms of scope - to the governing bodies of the economy, socio-cultural development, in the administrative and political sphere; by the method of making power decisions - to collegial and solely educational (sole) the like.

The system of government is characterized by the isolation of the corresponding group of government bodies that are part of a particular system from other types of government bodies; clearly defined composition of the system; the presence in the aggregate of the relevant state bodies of certain characteristics inherent in complex social systems, such as unity of purpose, functional self-sufficiency, hierarchy of organization, subordination, the relationship between structural units and the like. This is especially true for the development and adoption of management decisions, which are not only preceded by the collection and processing of information, but which themselves contain great information potential.

From the standpoint of establishing the purpose of regulatory mechanisms at various stages of the state, it should be pointed out that attempts to use the Soviet-style state apparatus with unprepared for this managerial staff could not be used to solve the tasks of regulating the activities of state authorities and the formation of new mechanisms of state governance in the independent Ukraine give positive results. Indeed, systemic crisis phenomena in the economic and social spheres 
of world social development testify first of all to the inefficiency of recent attempts to transform the public (state) management system in Ukraine in accordance with new political and ideological guidelines and socio-economic transformations. Unfortunately, governance at the national level and at the level of such a specific management object as the region turned out to be inappropriate public relations that have changed. At the same time, the organization of the administrativeterritorial structure of Ukraine has significant shortcomings that impede the acceleration of the transformation of public administration to a higher quality level, slow down the reform of public administration, and do not comply with European standards for the proper administration of a modern state.

In modern conditions, a significant part of the administrativeterritorial units is deprived of financial and economic resources, as well as the power to implement the principle of decentralization of governance regarding the socio-economic development of the state (as well as the region as a special management object). In order to put into practice the general principles of the structure of Ukraine as a unitary, in the constitutional sense, decentralized state, it is necessary to rationalize the state structure and administrativeterritorial division, abandon the mechanical identification of regions with regions, and constitute regions that are really composed on the basis of economic, demographic, cultural and other features and at the regional level to create a really working management system. In fact, the task of developing a universal management concept is being actualized - the formation of mechanisms for regulating the activities of public authorities based on the integration of management levels, optimizing the interaction of management institutions, and legal regulation of the purpose of regulatory mechanisms. Indeed, the content of public administration is often understood as the activity of the state, with the exception of the activities of the legislative branch and the judiciary. Such a negative formal definition does not reveal the essence of public administration, its purpose. 
Currently, it is precisely the problems of rationalizing the organizational and legal support for reforming public administration in the context of the transformation of the political system of Ukraine that actualizes a systematic approach to the activities of public authorities and management, establishing a socio-political dialogue, introducing European experience in adapting to supranational integration processes, developing local and regional systems self. Conducting a comprehensive reform of the power system in the context of accelerating integration processes in Europe, justified by the need to generalize historical, theoretical and practical knowledge in the field of public administration, develop practical recommendations and develop a system of effective means of implementing government and administrative influence in specific historical conditions of the transition period, the formation of prerequisites for the existence of civil society in Ukraine.

Given that the control object acts as a determining factor for the control subject, that is, it affects its construction, behavior, activity, choice of goals and the use of the entire array of means to achieve them, it is he who determines the form of power regulation that is adequate to him. That is why the formation and development of regulatory mechanisms is due to the modern approach to transformation processes in the public administration system, the transition in such a management system to the implementation of the principle of decentralization as the basis for modernization of the state. The study of the place and role of decentralization processes in the formation of democracy in society is becoming of paramount importance for both state-organizational processes and modern Ukrainian practice. Indeed, in the modern world there are no absolutely stable social organisms, because we are witnesses to the dynamic development of society. And if the corresponding dynamics of social development is large-scale, they usually speak of a transitional stage or transitional period. That is why they use the concept of a transitional society as a society in a state of transformation of the basic components of the political system.

Transformational changes are inherent not only in postcommunist countries as a transition from totalitarianism to democracy, 
but as the realization of a "democratic transition" in a society that carries out evolutionary transformation from one qualitative state to another, and it is in this process of transformation that a qualitatively new type of relationship arises. In this case, each sovereign state that implements transformational transformations should look for its optimal way to enter the global context, and at the same time integratively combine global positive experience, and its own traditions and peculiarities of adaptation of universal values ${ }^{20}$.

The content of the formation of regulatory mechanisms at the present stage of the creation of the state is the theoretical and methodological justification of public administration, the administrative and organizational directions of the state, structures, powers and features of public authorities. Administrative and organizational support for the formation of mechanisms for regulating the activities of public authorities should be defined as a system of interrelated elements: 1) goals and objectives of the state; 2) the state of the regulatory process, which is desirable to achieve in the process of developing legal norms governing the functioning of such a mechanism; 3) regulatory support for the development of public relations arising between the components of the state power system, between government at the state and regional levels. Under such conditions, each of the elements of the regulatory system is considered from the standpoint of a system-functional analysis, that is, as a component of the mechanism with its inherent functions, as well as an independent subsystem of authorities performing the functions established by the norms of legislation.

Since public authority by its nature tends to be centralized, the task of combining the principles of decentralization and subsidiarity in the functioning of regulatory mechanisms is becoming more relevant. Under certain conditions, the state is trying to increase its influence on public relations, even under the condition of a declarative strengthening

${ }^{20}$ Rebkalo V., Shkljar L. (2003) Politychni instytuty v procesi reformuvannja systemy vlady [Political institutions in the process of reforming the system of government]. Kyiv: Milenium. (in Ukraine). 
of the role of self-governing structures. First of all, such a phenomenon manifests itself in the form of concentration of the overwhelming majority of managerial functions at the central level of power by creating special and special regulatory mechanisms. The concentration of state power (centralization) is a fairly common managerial ideology in modern political systems. However, in the absence of effective regulatory subsystems, such a process will not be implemented if functional regulatory mechanisms do not work. That is why, in order to restore the optimal state of public power, modern European countries resort to decentralization of power. As part of this process, the redistribution of power and competencies between the central and local levels of public authority is carried out with a shift in emphasis to the local level in the implementation of functions predefined and guaranteed by the state. But European countries always began such a process with the formation of qualitatively functioning regulatory mechanisms.

That is why the main tasks of the formation of regulatory mechanisms should be defined in the format of the Concept for improving the mechanisms for regulating the activities of public authorities under decentralization: firstly, the identification of the components of the formation of such mechanisms in the system of public management activities; secondly, the introduction of a single, coordinated mechanism for the functioning of the system of legal support of state authorities, including: ensuring effective interaction and coordination of actions of state bodies, civil society institutions and citizens in this area, introducing a systematic approach to planning, resource support and control over the activities of authorities; thirdly, ensuring the effective functioning of monitoring the effectiveness of power, including a clear definition: the concept of a regulatory mechanism, a public administration mechanism; special and integrated regulatory mechanisms; adoption of regulatory legal acts based on the results of activity of the authorities.

In our opinion, the above conceptual approach is especially relevant in conditions of decentralization of power, since it requires clarifying the features of the development of decentralization processes, theoretical justification of the ways of reforming the public 
administration system and local self-government, adapting the public administration system of Ukraine with international standards of modern public administration, determining the essential characteristics of governance from the standpoint of regulation of the activities of authorities in a system many reforms. According to the main features (the source of power, the nature of the interaction between the subject and the control object, the nature of social norms), within the framework of a decentralized management system, public authorities carry out a regulatory impact on public relations. From such positions, it is advisable to talk about the effectiveness of decentralization in the context of the ability of authorities to implement the national reform policy.

\section{CONCLUSION}

The current state of socio-political development of Ukraine, the influence of the processes of modernization of power and Europeanization of governance on the public administration system require a conceptual review of the established patterns of relations between public authorities and civil society institutions, updating the entire government system. In these circumstances, decentralization as a modern challenge to the sustainability of governance requires the formation of an innovative model of the organization and functioning of public authority at the national, regional and local levels in the constitutional dimension objectified through the implementation of the principle of subsidiarity.

The relevance of the study of the processes of centralization and decentralization from the standpoint of their dichotomous relationship and impact on functioning is due to the solution of the problem of the effectiveness of state power in the context of the components of state power, levels of government and authorities as structural and functional units. The ability of state power to form innovative regulatory mechanisms in decentralized conditions characterizes the sovereignty of state power in the face of modern challenges. The process of decentralization is due to the modern approach to 
transformational processes in the public administration system, the need to rationalize management.

From the standpoint of developing a methodological concept for studying the processes of decentralization and the peculiarities of the formation of regulatory mechanisms, attention should be paid to the systematization of research approaches to decentralization as a process and phenomenon, highlighting the characteristics inherent in complex administrative systems, revealing the essence and structure of subjects of decentralization of power, analyzing the international experience of decentralization through determination European principles and standards of decentralization of power, in including as a structural and functional factor in the development of social relations, the development of a model of interaction "state - society". In this sense, decentralization of power should be understood as an institutionally determined procedure for political and legal approval of the rights and capabilities of administrative-territorial units and their administrative bodies to ensure rational management of the territory. In this process, the delegation of authority takes on a vertical direction, and involves the transfer of authority in part - from the center to the local level, and in part from the local level to the central level of public administration.

In this format, decentralization of power is not only a component of the reform of public administration, but it actually provides a subject field for studying regulatory mechanisms from the standpoint of determining the purpose, principles and content of regulation, the structural structure of such mechanisms, essentially changing the standard model of territorial administration to a model of multilevel management, within a nation state. In most modern studies (A. Batanov, V. Bordenyuk, V. Groysman, I. Drobot, etc.) the formalized dualistic model of decentralization in the framework of the system of "state power - local self-government". Such a model is based on two approaches that complement each other. The first approach involves maintaining the role of the state as an integrating factor in the process of creating the state, which provides a transformational model of the country's development; the second approach provides for the transfer of authority from government to local authorities (in accordance with the 
legal mechanism for securing authority in a particular area). In our opinion, the formation of modern regulatory mechanisms requires the solution of a basic managerial task: ensuring the functioning of public authorities to provide public services, satisfying the public interest, developing and implementing public management decisions. Moreover, there is a functional model of decentralization formulated within the framework of the modern traditional approach to this process as a combination of federalization, regionalization, municipalization.

An increase in the effectiveness of public administration in Ukraine is possible through the improvement of the forms, methods and mechanisms of public authorities based on the adaptation of the domestic theory of management of the development of administrativeterritorial entities in accordance with the principles of the EU regional policy and the introduction on a national basis of pan-European management traditions in accordance with the concept of the modern European integration process "From Europe of states to Europe of regions". In the framework of the post-Soviet state-administrative tradition of analyzing centralization processes, most domestic scholars focus on centralism as an institutional factor, which led to a deformation in the system of separation of powers, the only center of which remains the president of the country.

The dichotomy in the system of "centralization decentralization" has always characterized the capacity of state institutions to exercise certain powers, to ensure that the Constitution of Ukraine respects fundamental rights and freedoms. However, with the development of the state, semi-autonomous subsystems with a quasiinteraction function were formed in the system of public authorities at various levels. In fact, within the functioning of such subsystems, the coordination function of management is minimized, and the regulatory mechanism is formalized exclusively through legal regulation.

That is why the developments of a fundamentally new concept of regulating the activity of government bodies are updated, which provides: firstly, the functioning of integrated mechanisms for regulating the activities of government bodies based on the formation of effective vertically integrated subsystems of government bodies; 
secondly, the modernization of the institution of public service in the context of the concept enshrined in the Code of Administrative Procedure of Ukraine; thirdly, improving the activities of government bodies in creating a mechanism for the provision of public services to satisfy the interests of citizens (imperative of public interest) fourthly, creating a mechanism of political and public control over activities. In modern conditions, it is important to point out the emergence of a new concept of regulation of activities of state authorities in reforming the administrative-territorial structure of Ukraine.

The development and formation of modern mechanisms of public administration as an integral science involves the thorough development of a conceptual and categorical apparatus, whose task is to integrate the main categories, terms and concepts that determine the essence of a certain type of managerial activity and reproduce the most significant, regular managerial relations and relationships. Such categories are the basis of the theoretical and methodological substantiation of management mechanisms and regulation of the fundamentals of management activities, determine the level of adaptability of management systems to regulatory impact, and contribute to the systematization of scientific and practical approaches. So, the reform processes in the system of public authorities require a certain systematization and refinement of the wording, content and interpretations of such concepts, the structuring of scientific categories by content.

\section{SUMMARY}

The paper deals with theoretical and methodological grounds and development of practical recommendations to improve the institutional, administrative and organizational-legal mechanisms of regulation of the public authorities' activity in the context of the administrative reform. The system analysis of the essence and functioning of regulation mechanisms of the public authorities' activity is made; the peculiarities of the conceptual-categorical apparatus formation of the research are defined. The paper studies contemporary foreign (European) models of functioning of regulation mechanisms of the public authorities' activity, determines the place 
and role of the regulation mechanisms in implementation of the basic tasks and national state functions; the modern approaches to distribution of administrative powers between various levels of regulation mechanisms of the public authorities' activity in accordance with the principles of the delegated administration are systemized.

The approaches to solve the problem of the dichotomy of scientific categories "mechanisms of regulation" and "state regulation" are offered in the paper. The definition of the mechanisms of regulation of activity of bodies of state power as a complex of institutional, legal and administrative means, forms and administration methods, rational combination of which based on the system approach allows to change the normal regulation of the behavior of objects and subjects of administration on the regulatory impact of the subject for public relations is given.

It is established that the main problem is non-systemacy of the organizational-legal and administrative reform, subject discreteness of reforming and institutional asymmetry of the reforms content. The work proves that the unresolved challenge remains the classification mechanisms, forms, structures, approaches and instruments for regulation of activity of bodies of the state power aimed at solving the following administrative tasks: 1) formation of the integrated system of public authorities at central, regional, and sub-regional levels of administration, improvement of mechanisms of territorial administration in terms of decentralization; 2) creation of a modern model of rational interaction between bodies of the state power and bodies of local selfgovernment in terms of administrative reform in order to optimize procedures providing public (administrative, social, police, etc.) services, and the implementation of the rights and freedoms of citizens in the field of public administration; 3) organization of a modern system of training and retraining of personnel for maintenance of functioning of regulation mechanisms of state power bodies; 4) introduction of a new model of administrative-territorial division of the state; 5) systematization of means of the regulatory provision of the administrative reform implementation. 


\section{REFERENCES}

1. Averjjanov V. (2009) Ljudynocentrystsjka ideologhija jak osnova reformuvannja ukrajinsjkogho administratyvnogho prava $\mathrm{v}$ umovakh integhracijnogho procesu [Center-centered ideology as a basis for reforming Ukrainian administrative law in the context of the integration process]. Derzhava ta reghiony (Serija: Pravo), 2010, no. 2 , p. 87 .

2. Averjjanov V. (2009) Ljudynocentrystsjka ideologhija jak osnova reformuvannja ukrajinsjkogho administratyvnogho prava $\mathrm{v}$ umovakh integhracijnogho procesu [Center-centered ideology as a basis for reforming Ukrainian administrative law in the context of the integration process]. Derzhava ta reghiony (Serija: Pravo), 2010, no. 2, p. 92 .

3. Atamanchuk Gh. (2005) Ghosudarstvennoe upravlenye (orghanyzacyonno-funkcyonaljnye voprosy) : ucheb. posob. Moskwa [Public Administration Theory: A Lecture Course]. Юридическая литература.

4. Atamanchuk Gh. (2000) Ghosudarstvennoe upravlenye (orghanyzacyonno-funkcyonaljnye voprosy): ucheb. posob. [Public administration (organizational-functional issue): textbook. help]. Moskwa. Юридическая литература (in Russian).

5. Prykhodjko V. (2013) Mekhanizm derzhavnogho reghuljuvannja ta upravlinnja ekonomichnoju bezpekoju [The mechanism of state regulation and management of economic security]. Investyciji: praktyka ta dosvid, no. 15. pp. 6-8.

6. Radchenko O. (2013) Rodovi oznaky kateghoriji mekhanizm v socialjnykh naukakh [Generic attributes of the mechanism category in the social sciences]. Publichne upravlinnja: teorija ta praktyka, № 3. pp. 19-25.

7. Korotych O. (2006) Derzhavne upravlinnja reghionaljnym rozvytkom Ukrajiny [Public Administration of Regional Development of Ukraine ] Kharkiv:. Maghistr. (in Ukrainian)

7. Rudnicjka R. Sydorchuk O. 2014.Sutnistj ta zmist mekhanizmiv derzhavnogho upravlinnja ta pryncypiv jikh funkcionuvannja [The essence and content of the mechanisms of 
public administration and principles of their functioning]. Publichne upravlinnja: teorija ta praktyka. no. 4. pp. 50-60.

9. Prykhodchenko L. (2008) Sutnistj ponjatj mekhanizmiv derzhavy, derzhavnogho upravlinnja ta derzhavnogho reghuljuvannja [The essence of the concepts of mechanisms of the state, public administration and state regulation]. Aktualjni problemy derzhavnogho upravlinnja: zb. nauk.pr. no 3, pp. 269-274.

10. Fedorchak O. (2008) Klasyfikacija mekhanizmiv derzhavnogho upravlinnja [Classification of mechanisms of public administration]. Demokratychne vrjaduvannja : Naukov. visnyk LRIDU NADU. [Democratic Governance: Scientific. Bulletin of LRIDU NADU] (electronic journal), no. 1. Retrieved from: www.lvivacademy.com_O_Fedorchak.pdf. Accessed (5.11.2019).

11. Knjazjev V., Bakumenko V. (2002) Derzhavne upravlinnja: slovn.-dovidn. [Public administration: vocabulary reference]. Kyiv: UADU. (in Ukraine)

12. Nyzhnyk N. (1998) Systemnyj pidkhid v orghanizaciji derzhavnogho upravlinnja: navch. posib. [ Systematic Approach in Public Administration: Tutorial]. Kyiv: UADU. (in Ukraine)

13. Bashtannyk A. (2015) Konceptualjni zasady naukovogho analizu stanovlennja mekhanizmiv reghuljuvannja dijaljnosti orghaniv vlady v Ukrajini [Conceptual bases of the scientifically developed structure of regulation of power activity in Ukraine]. Efektyvnistj derzhavnogho upravlinnja: zb. nauk. pr. no. 43. pp. 281-286.

14. Meljnychenko V. (2004) Decentralizacija ta dekoncentracija publichnoji vlady na postradjansjkomu prostori: determinovanistj, znachennja, mezhi [Decentralization and deconcentration of public power in the post-soviet space: determination, meaning, limits]. Visnyk Khmeljnycjkogho instytutu reghionaljnogho upravlinnja ta prava, no 1-2, pp. 282-288.

15. Kom'jakov O. (2000) Derzhavne reghuljuvannja perekhidnoji ekonomiky [State control in a transition period economy] (PhD Thesis): Kyiv: Kyiv National Economic University.

16. Higher Attestation Commission (2007) Passports of specialties. HAC Bulletin of Ukraine. no 3, pp. 4-8. 
17. Bakumenko V. (2014) Pidkhid do vyznachennja pasportiv specialjnostej shljakhom systemnogho analizu derzhavnogho upravlinnja [An approach to the definition of specialty passports through a systematic analysis of public administration]. Aspekty publichnogho upravlinnja, no 3-4, pp. 5-9.

18. Merzljak A., Scryabina D. (2015) Derzhavna polityka skhidnojevropejsjkykh krajin u sferi jevrointeghraciji:perspektyvy adaptaciji dlja Ukrajiny [State Policy of Eastern European Countries in the Field of European Integration: Adaptation Prospects for Ukraine] Teorija ta praktyka derzhavnogho upravlinnja ta miscevogho samovrjaduvannja [The theory and practice of public administration and local self-government] (electronic journal), no. 1. Retrieved from: http://el-zbirn-du.at.ua/2015_1/13.pdf. Accessed (5.11.2019).

18. Shevchuk B. (2012) Jevropejsjki pryncypy nalezhnogho vrjaduvannja ta reforma systemy orghaniv vykonavchoji vlady $\mathrm{v}$ Ukrajini [European principles of good governance and reform of the executive power system in Ukraine]. Demokratychne vrjaduvannja. [Demokratychne vrjaduvannja] (electronic journal), no. 9. Rezhym from: http://www.lvivacademy.com/visnik9/ fail/Shevchuk_B.pdf. Accessed (5.11.2019).

19. Rebkalo V., Shkljar L. (2003) Politychni instytuty v procesi reformuvannja systemy vlady [Political institutions in the process of reforming the system of government]. Kyiv: Milenium. (in Ukraine).

\section{Information about the author:}

Alla Bashtannyk,

Candidate of Science in Public Administration, Deputy Director of the Dnipro Regional Branch,

National School of Judges of Ukraine 118, Gagarina ave., Dnipro, 49107, Ukraine ORCID ID: orcid.org/0000-0001-5691-2293 


\section{BALANCED USE OF RECREATION RESOURCES OF THE REGION: PUBLIC-MANAGEMENT ASPECT}

\section{Tetiana Bezverkhniuk}

\section{INTRODUCTION}

Any conversions to the operation and development of a recreational facility or tourist product is generally associated with the use of recreational and economic resources that have price and value. That is why the task of rational use of scarce resources, including investment, arises. Recreation requires constant investment, so investment provision and investment activity play a very important role in this process. Since investments are a factor that provides not only functioning but also future development, for tourism and recreational sphere they are an indicator of its development. The key to the effectiveness of investing into the recreational sphere is the transformation of recreational resources into the investment potential of recreational areas.

At the same time, in practice, there is a difficulty in organizing the process of investing into the tourism industry, which is related both to the lack of complete information on the availability and status of all types of recreational resources on the territory and their potential, as well as to the process of planning, programming, designing the rational use of recreational resources and management of the development of recreational areas, taking into account the interests of all stakeholders.

In recent years, there has been a widespread and dynamic implementation of project-oriented management at the regional level in Ukraine, which is due, first of all, to the complexity of solving the problems of organizing the process of investing and designing the rational use of recreational resources in the face of rapid changes in the environment and time and resources scarcity. Usually, public authorities develop a significant number of programs and projects that 
compete with each other for limited resources, may be interrelated or complementary, aimed at achieving one or more strategic goals for the development of the region. The implementation of a large number of programs and projects of different degrees of complexity requires the use of specialized management technologies, among which portfolio management is a leading place.

However, portfolio management techniques and tools, that are successfully used in the business environment, may not always be appropriate for public use or require some modification. This is related both to the features of the management system and to the characteristics of the portfolio and projects - the portfolio components. Thus, the peculiarities of the use of portfolio management methods by public authorities are: the duration of the portfolio implemntation as a whole, due to the periods of implementation of the strategy of socioeconomic development of a certain region; multi-vector portfolio, which should include components that correspond to all areas of the territorial community life; resource specificity and limitations related to regulatory, economic, geographical and other factors, etc. In addition, there are specific requirements for the portfolio management process, due to the need to review and re-evaluate the portfolio in relation to local budget adoption, changes in leadership, general political situation in the country, etc. ${ }^{1}$.

Therefore, the scientific justification for a comprehensive approach to the management of recreational resources at the regional level is extremely relevant. In spite of the considerable scientific interest in the subject, there is in practice not yet a rational use of recreational resources, and recreational potential has not been evaluated at the regional level at all. All this actualizes the scientific study of the main conditions and features of the organization of

1 Chykarenko I.A. (2009) Portfeljnyj pidkhid v upravlinni proektamy: adaptacija do sfery municypaljnogho menedzhmentu [Portfolio approach in Project Management: adaptation to municipal management area]. Publichne administruvannja: teorija i praktyka, vol. 1(1). Available at: http://www.dridu.dp.ua/zbirnik/200901/Chikarenko_IStat.pdf (accessed 5 September 2019) 
effective recreational activity in the region and substantiation of a comprehensive approach to the rational use of resources.

\section{The role of public authorities in ensuring a balanced use of the region's recreational resources}

The scientific substantiation of a comprehensive approach to the management of recreational resources at the regional level, first, requires a clear definition of the role of regional authorities in the development of recreational activities.

In our view, regional management of recreation and tourism should be considered as: the activity of public authorities to create conditions for the rational and effective use of the region recreational potential; organizational and legal provision and practical implementation of the strategy/program for the development of recreational activities in the tourist sub-regions; regulation of subjectobject and subject-subject relations arising in the process of using recreational resources at the regional level, with the aim of ensuring the reconciliation of internal and external interests of different stakeholders of recreational activities, as well as their harmonization with the interests of the local population of tourist sub-regions (recreational zones) and the opportunities of the region.

For the effective functioning of the system of regional recreation and tourism management, the correct consideration is given to the principles of subsidiarity and compliance of the management entity with its object, which most closely reflect the regional specificity. That is, it should be, first, a study of the internal specifics, features, functions and potentials of the region recreational resources (as an object of regional management) inherent in the region's tendencies of recreational activities in order to alternatively select the optimal path of development of each recreational zone (tourist subregion) from taking into account generally recognized regional interests. This approach requires the identification of factors of formation of the regional situation of the recreation development and the development of a complex of models that reflect: recreational activity as a dynamic complex-organized hierarchical system; 
conditions of its components functioning; a recreational activity environment as an object of management ${ }^{2}$.

Under the regional situation of recreation development, we consider the state of all types of recreational resources within a certain territory in a certain period of time in order to identify the type of problems in recreational activity in the territory and its development trends. In this case, from the point of view of regional management, we can talk about the definition of recreational zones as territories of the region, in which a unique recreational situation is formed and a special program of development and specific mechanisms of state support are implemented. However, it should be noted that in such an approach, a recreational zone, such as a territorial (spatial) unit of a region, is not subject to direct influence by public authorities. The object of public management is the processes that occur within the recreational areas.

To ensure effective administrative actions by public authorities to optimize recreational activity at the regional level, it is advisable to carry out typification of recreational areas in the region. For example, for the typification of recreational zones of the Odesa oblast we have evaluated the following potential types:

-assessment of the natural and geographical recreational potential. The analysis of regional peculiarities of recreational potential formation was the basis for distinguishing the following factors of natural recreational resources: bioclimatic; geomorphological; structural elements of the ecological network, balneological and modern ecological status;

-assessment of socio-historical recreational potential. The experience of many countries around the world shows that historical and cultural sites can be decisive in shaping the demand for recreational resources and have a significant impact on revenue

${ }^{2}$ Edited by Izha M.M., Babov K.D., Bezverkhniuk T.M. (2016). Rehionalniy turystychniy produkt: proektniy pidkhid do zabezpechennya konkurentospromozhnosti [Regional tourism product: a project approach to ensuring competitiveness], Monograph. Press ORIDU, Odesa, 626 p. [Ukraine] 
generation. If the criteria and methodology for the assessment of natural recreational resources are well developed, there is no generally accepted scheme for the evaluation of historical and cultural resources. In order to determine the socio-historical recreational potential of the administrative regions of the Odesa oblast, an assessment was made of: cultural and historical recreational resources, natural and social recreational resources, event and attractional recreational resources;

-the assessment of investment recreational potential is based on a summary assessment of the potentials of infrastructure, finance, investment and the social component.

When analyzing recreational resources and determining the components of the recreational potential of the Odesa oblast, we paid attention to the fact that the nature of the placement of recreational facilities depends on the location of the infrastructure sites of attraction - in the conditions of the region, their placement determines the placement of recreational facilities. That is why we consider it advisable to pay attention to the potential of unused recreational resources in the process of identifying and typifying of recreational zones, which in our view is the basis for the effective development of recreation in the region.

In the Odesa oblast there is already formed a recreational complex, which represents a set of objects of recreation and infrastructure, which are focused on natural recreational resources. However, structural relationships were formed in the 1960's and 1970 's function poorly today. Changing development vector, systems of socio-economic relations, production depreciation of fixed assets cause insufficient efficiency of functioning of the region in the conditions of intensive development of world markets of recreational services. In the economy, this situation is seen as an increase in demand with a steady supply. This process cannot last endlessly, because if such a trend persists for a certain period of time, the proportion of consumers (tourists) are looking for other markets for services. A similar situation is currently present in the recreational space of Odesa. In order to overcome this development crisis, it is 
necessary to identify the untapped recreational potential of the region and justify the possibilities of reforming the sector.

The condition of effective spatial organization and development of the region is the use of untapped recreational potential. The study of the structure of available recreational resources shows their developed nomenclature, which is represented by natural-climatic, naturalanthropogenic and socio-economic potential. Modern types of recreation require a balanced use of untapped resources, for the formation of all-season recreation with different types of attractions. Priority research of modern recreation is to justify the spatial location of the resource base. It is advisable to carry out a comparative analysis of the spatial location of recreational resources and the intensity of functioning of the recreational sphere of the region in order to assess the potential for the placement of untapped recreational resources.

To make effective management decisions on the rational use of recreational resources in the region, it is necessary to have up-to-date, complete and comprehensive information on their current state. The most adequate reflection of the situation regarding the use of recreational potential and the development of recreational activity is the cartographic model, as a basis for creating a database and knowledge base on the structure, dynamics and organization of recreation in the territory of the region, its spatial and temporal hierarchy. That is, the fundamental scientific basis of a comprehensive approach to regional management of the development of recreation and tourism should be a knowledge base on a set of features, benefits, varieties that can be used to organize the process of investing in the recreational sector of the region.

The information component of a comprehensive approach to the management of recreational resources at the regional level should provide the necessary and sufficient inventory of data to compile a complete picture of the state and dynamics of development. To date, the amount of information that characterizes the quantitative and qualitative state of the elements of the recreational environment of the region reaches up to hundreds of indicators - they are collected, processed and accumulated by various entities of management and 
recreational activity. As a result, a huge amount of information is accumulated, which is difficult to coordinate with one another, is fragmentary, does not give a complete idea of the region recreational potential at all. That is, it is necessary to create such an information and infrastructure component of the model of recreational potential of the region, which would ensure the distribution of types and volumes of information received, legal legitimacy, completeness, authenticity, relevance, etc.

Assessment of the recreational potential of the territory serves as a basis for the adoption of effective management decisions to optimize, rationalize the spatial economic organization of territorial recreational systems, determine the value of individual resources, identify territorial differences in resource availability and identify ways of rational use of resources and balance by the regional authorities.

It should be emphasized that in the current conditions of decentralization, the dominant role of regional authorities in ensuring the strategic goals of regional development is the organization of an effective investment process, in particular in the recreational sphere. Investing in the recreational sphere is a process (a set of sequential actions) of attracting (motivating) an investor (or their totality) to investing investment resources in the creation / operation / development of recreational facilities in order to achieve the effective development of the recreational territory based on the harmonization of interests of participants in this process. which have beneficial socioeconomic effects and benefits, including expected profitability in the form of tangible income. Investing takes place through an investment project, the realization of which is organized according to the legally defined mechanism of investment activity.

\section{Determining the investment potential of the recreational area} is the basis for a balanced use of resources

The prospect of investing in the tourism and recreational sphere has been sufficiently substantiated with scientific papers and analytical documents. There is no doubt that global demand for wellness tourism 
is increasing. The key to the effectiveness of investing in the recreational sphere is the transformation of recreational resources into the investment potential of recreational areas.

Considering the peculiarities of investing in the recreational sphere, it is important to focus on the following ${ }^{3}$ :

1) recreational area (zone) is different from any other area in that it is a complete territory, different from other favorable for the development of recreation by the combination of natural conditions, resources and recreational objects. The development of a recreation area (zone) is not possible without the construction of roads, hotels and resorts, provision of the new recreational areas with necessary facilities, the creation of a park area and more. In this connection, one of the most important problems arises in ensuring the conditions of development of the recreational area (zone) - the limited investment resources for the implementation of long-term infrastructure projects;

2) it is possible to secure the inflow of investments into the recreational sphere of the region only by two means:

- direct - statutory regulation of investment activity (creation of preferential conditions and preferences for investors);

- indirect regulation based on the assessment of the investment attractiveness of the recreational area (zone) - the amount of capital investments that can be attracted to the recreational sector of the region based on the investment potential and the level of investment risks. Therefore, investment potential is the main indicator of the investment attractiveness of a recreational area.

The investment attractiveness of a recreational area (zone) is a set of objective prerequisites (features, factors, means) and opportunities of the recreational area that determine the demand for investments that can be attracted to the recreational sphere with the aim of its development, based on its inherent investment potential and the level of investment risks. In other words, the investment

${ }^{3}$ Edited by Herasymenko V.H. (2016). Otsinka turystychno-rekreatsiynoho potentsialu rehionu [Assessment of the tourist and recreational potential of the region], Monograph. Press ONEU, Odesa, 262 p. [Ukraine] 
attractiveness of the recreational area (zone) is a generalized characteristic of the investment potential of the territory in terms of prospects, benefits, efficiency from use and minimization of investment risks.

The investment potential of the recreational area can be viewed from two points of view, based on its components:

- formation of investment potential;

- usage of this potential.

The formulation of the task of developing a recreational territory may look like this: it is necessary to choose a development option in which the available potential allowed at least one way to achieve the expected results.

Formation and development of the investment potential of the recreation area occurs within certain limits or taking into account the principles that determine its use:

1. Taking into account the strategic goals of development of the region in the formation and expansion of the investment potential of the recreational territory. The size of the potential should be sufficient to ensure the development of the recreational area, in accordance with the chosen investment strategy;

2. Provision of flexibility of investment potential to influence of factors of internal and external environment, prompt reaction to changes of investment climate, emergence of new investment opportunities;

3. Ensuring diversified use of investment potential, facilitating the redistribution of unused resources between different investment projects ${ }^{4}$;

4. Consideration of the life cycle stage of the recreational area when using the investment potential.

${ }^{4}$ Komarova M.Ye. (2011), Metodologicheskiye podkhody $k$ otsenke turistskorekreatsionnogo potentsiala: regionalniy aspect [Methodological approaches to the assessment of tourist and recreational potential: regional aspect], Monograph. Press IPK NIU «BelGU», Belgorod, 144 p. 
In the conditions of globalization of economic processes against the background of market environment dynamism, the basis of stable development of recreational territory and its effective functioning becomes the choice of strategy of investment development taking into account the phase of the life cycle of the recreational territory.

Based on the analysis of successful international experience, we can identify the following effective strategies for investing in the development of recreational territory:

1) recreational territory of active attraction with sustainable development of tourist and recreational infrastructure - an innovative strategy focused on the development of the territory as a tourist destination, the formation of a complex recreational and tourist product and the development of a marketing model for its effective promotion to the domestic and world markets;

2) recreational territory with developed tourist and recreational infrastructure but with great potential of unused recreational resources - a motivational strategy aimed at improving the quality of tourism product and recreational services, forming a portfolio of investment projects for the development of new types of recreational product for the territory;

3) a recreational area with significant recreational potential, but with a pioneering level of tourism and recreational infrastructure development - a supportive strategy, a priority type of investment in clusters;

4) recreational territory with a unique set of recreational resources, but with a low level of tourist attractiveness - an evolutionary strategy focused on the creation of infrastructure for the use of a priority type of recreational resource with connection to the tourist routes network;

5) recreational territory of long-range development in the long term - an explanatory strategy, investing in the establishment of strategic and programmatic documents of development.

In order to evaluate the investment potential of the recreational area, one should consider such factors as:

- the ability to attract investors' attention; 
- availability of up-to-date proposals for investing into the project.

It should also be borne in mind that the investment potential of one area is very closely related to the potential of another one. Interconnected they form the investment potential of the region.

The main methodological approaches to the assessment of the investment potential of the recreational area and its components are the value approach, expert evaluation, evaluation based on a generic indicator, a comprehensive approach ${ }^{5}$.

It is important to emphasize that investment potential is a motive for which, besides the owner of the investment resources, the entities in need of investment should be involved. Therefore, this process requires targeted coordination.

In the process of assessing the investment potential of recreational areas, the case of the Odesa oblast, a comprehensive approach was used, which included a comprehensive assessment of investment potential by major groups of indicators. The assessment of investment potential was carried out using the balance method, which is the basis for the comparative analysis of the investment opportunities of the territory according to certain blocks of indicators, which are taken for equivalent categories.

Specific features that were taken into account in the process of assessing the investment potential of recreational territories of the Odesa oblast:

- selection of indicators (block 1 - production potential; block 2 - social potential; block 3 - financial potential) depended on information security: official statistics data and open data on sites of rayon state administrations;

5 Zdrenyk V. S. (2016), "Investytsiynyy potentsial: sutnist ponyattya ta problemy otsinky" ["Investment potential: the essence of the concept and problems of valuation"], journal Naukoviy visnyk Uzhhorodskoho universytetu [Uzhgorod University Scientific Bulletin], vol. 1, pp. 363-367. [Ukraine] 
- taking into account different units of measure and different directions of optimization, normalization of estimates was carried out for each selected indicator;

- the score for each of the blocks of indicators was carried out by summing the scores taking into account the coefficients of significance;

- each block consists of indicators that are adjusted by the coefficients of significance when it is necessary to reduce or increase the weight of the impact of the indicator on the overall assessment of the respective block, reflecting the degree of direct impact on investment processes in the recreational sphere. Thus, all indicators were divided into the main ones - key factors that should be weighted; neutral - significantly affect investment processes but do not need to increase in importance, and minor, which need to be reduced. The choice of significance coefficients reflects their corrective nature and does not allow significantly overlap the estimates;

- the distribution of points for each block depended on the maximum and minimum values in the blocks; the block integral estimate is calculated by geometric mean, which allows to take into account the multiplicative effect of the impact of indicators on investment processes.

Integral assessment of the investment potential of the recreational territories of the Odesa oblast allowed zoning of the territory with the allocation of 5 zones with priority investment strategies: 1) an innovative strategy focused on the development of the territory as a tourist destination; 2) a motivational strategy aimed at increasing the quality of tourism products and recreational services; 3) a supportive strategy with priority investment in clusters; 4) an evolutionary strategy focused on the creation of infrastructure for the use of a priority type of recreational resource with connection to the tourist routes network; 5) explanatory strategy, investing in the development of strategic and programmatic development documents.

The practical implementation of the investment model of complex development of recreational territories of the Odesa oblast is 
connected, first of all, with the use of investment resources of the territories that have their price and value. Therefore, the main principle of the model implementation is the principle of rational use of limited investment resources.

The aggregate of all resources of the recreation area, capable of ensuring the stable growth of the main socio-economic indicators, is its investment potential, the current level of which is a decisive factor in the selection of types of investments and investment objects. Therefore, taking into account the principle of rational use of investment resources, priority areas of investment are those that will ensure the effective implementation of the recreational zone of its main recreational functions. The introduction of the investment model will increase the investment potential of the recreational territory, which will make it possible to implement projects focused on ensuring the fulfillment of the territory by its functions, and, subsequently, the development of the territory as a tourist destination, the formation of a comprehensive recreational and tourist product and its effective promotion to the world tourist market.

Based on the above principles, depending on: life cycle stage of the recreational area; the level of its investment potential; major and minor recreational functions; defined investment strategies; the availability of unused resources, the investment objects were divided into groups:

- short term prospective investment objects, which are in line with the strategy of development of the recreational area in terms of its basic recreational function, and for which both investment potential and recreational resources are available; as well as facilities that provide additional functions - only in the case of territories with sufficient investment potential (group of investment objects $1^{\text {st }}$ queue);

- medium-term prospective investment objects, that are consistent with the recreational territory development strategy in terms of performing secondary functions for which recreational resources are available, but investment potential is insufficient at present; relevant investment projects can be implemented under conditions of 
sustainable development of the recreational area and increase of its investment potential; for areas with sufficient investment potential, projects aimed at using untapped resources are also possible (group of investment objects $2^{\text {nd }}$ queue);

- long-term prospective investment objects, that are in line with the development strategy of the recreational area in terms of performing secondary functions for which untapped resources are available (or additional research is needed to identify and measure the recreational value of those resources), but insufficient investment potential (group of investment objects $3^{\text {rd }}$ queue).

The complexity of solving the tasks of organizing the process of transformation of recreational resources into the investment potential of recreational territories determines the expediency of implementing methods of portfolio management of investment projects into the practical activity of the regional authorities.

\section{Project-oriented management of balanced use of recreational resources}

Today, one of the most efficient approaches to organizing a balanced use of recreational resources is project management within the tourist and recreational destination. After all, a tourist and recreational destination is an integrated set of various investment projects for the creation of objects of recreation, leisure and entertainment; development of local transport and communications; formation of health and tourism infrastructure; marketing program implementation, etc.

Project management has undeniable benefits. However, there are also issues that are related, first of all, to the limited life of the project, its seclusion and isolation. A project is the best tool for achieving a specific goal. The most important task is precisely the formulation of the project purpose, the peculiarity of which is that the implementation of the goals of individual projects in the aggregate ensures the fulfillment of strategic objectives of the destination as a whole. When implementing a large number of projects that are combined for a single strategic purpose, it is important to evaluate 
each project individually and evaluate the overall program or portfolio of projects. In particular, it is necessary to initiate each project and, once completed, adopt its results in line with the strategic goals. Also important for the implementation of a large number of projects is the rational distribution and redistribution of recreational resources between individual projects. In case of resources scarcity, it is necessary to organize their redistribution taking into account the priority of projects. A decision may also be taken to suspend, close the postponement of certain projects in view of changes in the portfolio/ program environment, shift market focus, refine strategy, etc. Finally, purposeful collection, accumulation, analysis and synthesis of the results of individual projects is necessary.

Therefore, effective management of destination development projects (recreational zone), compensation for isolation and limited project life require continuous integrative activities. Each of these projects does not exist by itself, but only in cooperation with others, the joint implementation of which will allow to achieve a strategic goal or a higher level goal. These projects form a comprehensive Recreational Area Development Program, which is no longer a set of activities, but a set of interrelated projects of various types: financial, organizational, technological, technical, marketing, infrastructure selected for implementation based on common selection criteria. The following is the division of projects between the sectoral enterprises of the tourist and recreational sphere and the formation of clusters responsible for the implementation of a portfolio of projects tied to a specific territory.

A portfolio is a set of projects or programs and other work combined to manage effectively these works to achieve strategic goals ${ }^{6}$. The concepts of portfolio of projects and program are close. Like the portfolio of project, the program brings together a number of

${ }^{6}$ Sencha I.A. (2016) Obghruntuvannja optymaljnosti portfeljnogho pidkhodu pry realizaciji antykryzovykh strateghij [Justification of the portfolio approach optimality in the implementation of the anti-crisis strategies]. Derzhava ta reghiony. Ser.: Derzhavne upravlinnja, vol. 2(54), pp. 20-24 
projects and programs, as well as individual works outside the projects, to coordinate and effectively manage them together. However, all projects included in the program are interconnected and interdependent, all aimed at achieving a common goal, and projects and programs included in the portfolio are not necessarily interdependent or directly related, they are combined in time and in part terms of implementation.

In order to understand the importance of implementing portfolio management to ensure a balanced use of recreational resources, it is important to emphasize its fundamental difference from project management. That is, if the purpose of managing an individual project is to create a product in a timely manner and within budget, then the purpose of portfolio management is to obtain the greatest return on the implementation of the entire set of projects. Implementation of portfolio of projects is focused on the achievement of strategic goals on the set of completed portfolio of projects.

From a strategic management perspective, projects are tools for solving the tasks obtained as a result of the decomposition of a strategy. To improve project management of implementation of strategies, they create portfolios / programs of projects. Therefore, the main difference between a portfolio of projects is its strategic orientation. Combining projects in a portfolio allows you getting a new quality of management, enhance the overall effect of project implementation, and the portfolios of project themselves become one of the most effective mechanisms for strategic management of the development of tourist and recreational destinations.

Thus, the portfolio approach to the management of the tourist and recreational destination development involves: prioritization of projects in accordance with the strategic objectives of the territory development; allocation of resources between projects according to priorities.

The selection of projects into the strategic portfolio involves the following:

- determination of the optimal and acceptable number of projects in the portfolio; 
- ensuring, that projects are consistent with strategic plans.

Thus, the organization of an adequate system for managing the strategic portfolio of projects of tourist and recreational destinations development creates a number of significant advantages:

- implementation of potential projects in terms of their value and benefits to stakeholders in accordance with current strategic goals;

- determination of the optimal or acceptable number of projects in the portfolio;

- ensuring, that projects are consistent with strategic plans;

- provision of different projects types balancing in terms of goals and benefits, provision of opportunities, benefits and risks balancing.

In the aspect of our research, the fundamental issue is the responsibility for the formation, management and implementation of a portfolio of tourism and recreation destination development projects. Naturally, it should be a local public authority, which is legally responsible for formulating strategic priorities and programs for the territory development. However, the key to portfolio management is the competence of the staff and the level of maturity of the organization implementing the project approach.

Elaborationg a strategy for tourism development and recreation in the region, an appropriate structural subdivision of a public authority, when planning new strategic goals, should consider them through the prism of the project approach. For example, in the next 3 years it is planned to launch a new sanatorium and resort complex, to open 10 new cultural and entertainment centers, to improve the transport network and to reposition the brand of the resort area. If all these projects are really considered as projects and if there are 45 such projects, then the question of priority arises. How to define them, how to manage them in dynamics? In addition, if in the tourist market the situation (demand change) suddenly changes - do we leave the project, do we exclude it from the list of strategic and priority ones, or continue? 
Indeed, sometimes strategic goals can be achieved less than initially planned by the number of projects in the portfolio. On the other hand, the decision to stop an important project may affect other projects and halt the overall growth of the destination for years to come. In order to understand such opportunities, risks and threats, an appropriate organizational structure is required - the Project Portfolio Management Office (Strategic Tourism Development Board).

Strategic project portfolio management processes can be summarized in two main categories:

- monitoring and control of the whole portfolio. This process is necessary to confirm that the implementation of the projects is in line with the strategic goal of the destination development, ensures the efficient use of resources and investments;

- assessment of strategic changes, decision making. During the life cycle of the portfolio, there are constant changes in the external and internal environment of the destination. These changes significantly affect the definition of success criteria and policy benchmarks. For example, a change in senior management may lead to the setting of new strategic goals, a change in the current market situation may affect the cost and timing of output of portfolio projects. Accordingly, strategic goals and priorities should be reviewed on an ongoing basis. The portfolio needs to be re-viewed and balanced.

Today, in Ukraine, strategic planning for the tourism industry development has already been properly evaluated, and managers recognize the important role of professional management of programs/ portfolios, starting with defining the strategy for the development of tourism and recreational sphere and ending with the implementation of individual projects. However, a common misconception is that many do not pay attention to the clear relevance of the portfolio of projects to the development strategy.

Creating strong links between strategy and multiple projects allows you maximizing value and achieving optimal focus on turning the strategy into life. Nevertheless, most often the links between 
strategy and projects are the weakest points in the tourism management system in Ukraine.

\section{CONCLUSIONS}

The study of the main conditions and features of the organization of effective recreational activity at the regional level has made it possible to prove that the regional management of recreation and tourism should be considered as the activity of public authorities to create conditions for the rational and effective use of the recreational potential of the region. Proper consideration of the subsidiarity principles and the entity's compliance with the entity that most closely reflect regional specificity is of paramount importance. The information component of a comprehensive approach to the management of recreational resources at the regional level should provide the necessary and sufficient inventory of data to compile a complete picture of the state and dynamics of development.

Emphasizing the effectiveness of implementing portfolio management as a technology capable of ensuring a balanced use of recreational resources through the implementation of a set of strategic-oriented investment projects, it is important to focus on the following. There are at least four groups-directions of investments in the recreational sphere: investments aimed at nature conservation; investments that are renewable in nature; investments of a capital nature, that is, in the acquisition or manufacture of the tangible and intangible assets of the tourist and recreational infrastructure on their own use; investments in the development of new innovative types of recreation and tourism, the development and implementation of innovative technologies aimed at improving customer service and expanding service opportunities. If there are investment projects in the development portfolio of the recreational zone in all four directions, it is possible to ensure a balanced use of recreational resources and to predict the effective implementation of strategic goals. 


\section{SUMMARY}

In the article, based on the study of the main conditions and peculiarities of the organization of effective recreational activity on the case of the Odesa oblast, it is proved that modern types of recreation require balanced use of resources for the formation of all-season recreation with different types of attractions. It is substantiated that regional management of recreation and tourism should be considered as an activity of public authorities to create conditions for rational and effective use of the recreational potential of the region. It has been emphasized that transformation of recreational resources into the investment potential of recreational territories is the key factor to the effectiveness of investing in the recreational sphere. Effective strategies for investing in the recreational sphere have been identified. It is proved that one of the most effective approaches to the organization of balanced use of recreational resources is portfolio management within the tourist and recreational destination.

\section{REFERENCES}

1. Chykarenko I.A. (2009), "Portfeljnyj pidkhid v upravlinni proektamy: adaptacija do sfery municypaljnogho menedzhmentu” ["Portfolio approach in Project Management: adaptation to municipal management area"], journal Publichne administruvannja: teorija $i$ praktyka [Public administration: theory and practice], vol. 1, pp. 1723. [Ukraine]

2. Edited by Izha M.M., Babov K.D., Bezverkhniuk T.M. (2016). Rehionalniy turystychniy produkt: proektniy pidkhid do zabezpechennya konkurentospromozhnosti [Regional tourism product: a project approach to ensuring competitiveness], Monohraph. Press ORIDU, Odesa, 626 p. [Ukraine]

3. Edited by Herasymenko V.H. (2016). Otsinka turystychnorekreatsiynoho potentsialu rehionu [Assessment of the tourist and recreational potential of the region], Monohraph. Press ONEU, Odesa, 262 p. [Ukraine]

4. Komarova M.Ye. (2011), Metodologicheskiye podkhody $k$ otsenke turistsko-rekreatsionnogo potentsiala: regionalniy aspect 
[Methodological approaches to the assessment of tourist and recreational potential: regional aspect], Monograph. Press IPK NIU "BelGU", Belgorod, $144 \mathrm{p}$.

5. Zdrenyk V. S. (2016), "Investytsiynyy potentsial: sutnist ponyattya ta problemy otsinky" ["Investment potential: the essence of the concept and problems of valuation"], journal Naukoviy visnyk Uzhhorodskoho universytetu [Uzhgorod University Scientific Bulletin], vol. 1, pp. 363-367. [Ukraine]

6. Sencha I.A. (2016), "Obghruntuvannja optymaljnosti portfeljnogho pidkhodu pry realizaciji antykryzovykh strateghij" ["Justification of the portfolio approach optimality in the implementation of the anti-crisis strategies"], journal Derzhava ta reghiony [State and regions], vol. 2 (54), pp. 20-24. [Ukraine]

\section{Information about the author: Tetiana Bezverkhniuk,}

Doctor of Sciences in Public Administration, Professor,

Chair of the Project Management Department, Odessa Regional Institute for Public Administration of the National Academy for Public Administration under the President of Ukraine 22, Henuezka str., Odesa, 65009, Ukraine ORCID ID: orcid.org/0000-0002-2567-8729 
DOI https://doi.org/10.36059/978-966-397-162-9/53-87

\section{MODEL OF PUBLIC AUTHORITIES \\ AT REGIONAL LEVEL IN UKRAINE: GENESIS, STATE AND PROSPECTS OF REFORM}

\section{Yevgeniy Borodin}

\section{INTRODUCTION}

Going into the post-Soviet period of its history, Ukraine had to solve the problem of the system of public power, which is significantly different from the system of "power of the Soviets". The Soviet model envisaged the state control of all levels of public management and administration and the lack of local self-government as a form of public authority. In the early 1990s, the process of governmental development at the regional level began, and continues to this day. Certain reform projects have been developed over the last three decades, and some of which have been still discussed today.

Following the change of power as a result of the Euromaidan, the issue of reforming the model of public administration at the regional level of Ukraine has become particularly relevant and has been included on the reform agenda. At the same time, it is possible to analyze not only the experience and current state of the issue of improving the model of public administration at the regional level, but also the prospects for its further resolution.

The administrative and territorial structure of independent Ukraine has not changed in comparison with the times of the USSR, when there were 24 oblasts, cities of republican subordination Kyiv and Sevastopol and the Autonomous Republic of Crimea. Our research is focused on public authorities in the regions of Ukraine, which are the main unit of administrative and territorial division of the country at the regional level. It is a question of a regional council as a regional body of local self-government and a regional state administration as a public authority of general competence. 


\section{Search for a model of public administration at the regional level in the context of confronting the presidential and Soviet verticals}

First of all, let us turn to the historical aspect of the question, which allows to identify and evaluate previously applied approaches to the creation of regional executive bodies and local self-government.

Independent Ukraine inherited from the USSR an outdated system of public administration built on a "Soviet model" of governance, in which a hierarchy of Soviet type elected councils of different levels and their executive committees existed. The introduction of the concept of "local self-government" at the USSR and Ukrainian (1990) levels did not lead to a rapid separation of local self-government bodies from state authorities, even at the legislative level. In the text of the Constitution of Ukraine in force until 1996, which was the Basic Law of the USSR of 1978 with certain changes of the times of perestroika and independence, up to the last moment all local councils of people's deputies (including regional ones) were considered to be "the bodies of public authorities". The Constitution itself did not mention local self-government bodies, but in the Law of Ukraine "On Local Councils of People's Deputies of the Ukrainian SSR and Local Self-Government" (December 7, 1990) the Regional Councils of People's Deputies (as well as village, settlement, district, city, district in cities) has been defined as "state bodies of local selfgovernment"1. This formulation, despite its absurdity, made it possible to remove for a certain period the agenda of reforming the system of local authorities.

The introduction of the Presidency Institute in Ukraine has put on the agenda the question of building a "presidential vertical", which should be extended to the oblast and rayon (district) levels. After the

${ }^{1}$ Verkhovna Rada of the Ukrainian SSR (1990), Zakon Ukrayins'koyi RSR "Pro miscevi Rady' narodny'x deputativ Ukrayins'koyi RSR ta misceve samovryaduvannya” [Law of the Ukrainian SSR "On the Local Soviets of People's Deputies of the Ukrainian SSR and Local Self-Government"], 07.12.1990, No. 533-XII as amended of 07.12.1990, available at https://zakon.rada.gov.ua/laws/show/533-12/ed19901207, accessed 25 October 2019. 
first ever presidential election in Ukraine (December 1, 1991), the issue of executive bodies at the regional and sub-regional levels was examined in a concise period, which at the same time led to a revision of the position of lawmakers on the essence of councils as public authorities. A course was taken to create such state structures of general competence that would take over the real power in the regions and districts.

On March 5, 1992, the Verkhovna Rada of Ukraine adopted the Law "On the Representative of the President of Ukraine", according to which the position of the representative of the President of Ukraine was created in the regions (oblasts), cities of Kyiv and Sevastopol, districts (rayons), districts of the city of Kyiv as the highest official of the state executive power in the respective state territorial unit. The position was officially called "Representative of the President of Ukraine - Head of the local state administration". Thus, the first executive bodies in the regions appeared in the history of independent Ukraine, and they became the regional state administrations. At the same time, they were, so to say, a "minor" element in the lawmaking process, since the focus was on the representative of the President of Ukraine although he/she was only an official. Nevertheless, the whole structure of regional power was built not from the authority body, but from its head. The Representative of the President of Ukraine was vested with the right to form a local state administration, determine its structure and staff (in agreement with the President of Ukraine). The activity of the regional state administrations was regulated by the "Provision on local state administrations", which was approved by the President of Ukraine (first approved on April 14, 1992) ${ }^{2}$. In the Law of Ukraine "On the Representative of the President of Ukraine" the issue of the primacy of the Representative of the President of Ukraine regarding the regional state administration was resolved by granting

${ }^{2}$ President of Ukraine (2001), Ukaz "Pro Polozhennya pro miscevu derzhavnu administraciyu" [Decree "On the Regulations on Local State Administration"], 14.04.1992, No. 252, available at https://zakon.rada.gov.ua/laws/show/ru/252/92, accessed 25 October 2019. 
the status of a legal entity to the Representative of the President of Ukraine and not to the regional state administration. However, unlike the President of Ukraine, the Representative of the President of Ukraine was not a siole executive body but only the head of an administration.

The Law of Ukraine "On the Representative of the President of Ukraine" stated that "the legal status of the local state administration is determined by the Constitution of Ukraine, this Law and the Regulations approved by the President of Ukraine"3. The document referred to the structure of the state administration, which included departments, offices and other services. Heads of regional state administrations and its structural units were prohibited from being members of parliament or members of local councils, to combine their positions with senior positions in the public and business sectors, and to engage in business activities. In fact, restrictions were imposed on civil servants, whose status was settled only in December 1993.

In the Law of Ukraine "On the Representative of the President of Ukraine", a section on the relations between the Representative of the President of Ukraine and local self-government was singled out (in 1992-1996 the term "local and regional self-government" was used in Ukraine). The basic approaches to cooperation of the head of the regional state administration with the relevant regional council were as follows:

- The Representative of the President of Ukraine promotes the development of local self-government and supervises the activity of local self-government bodies;

- Heads of village, town and city councils are responsible to the Representative of the President of Ukraine for the exercise of delegated powers;

${ }^{3}$ Verkhovna Rada of Ukraine (1992), Zakon Ukrajini "Pro Predstavny'ka Prezy'denta Ukrayiny', [Law of Ukraine "On the Representative of the President of Ukraine"], 05.03.1992, No. 2167-XII, available at https://zakon.rada.gov.ua/laws/ show/2167-12, accessed 25 October 2019. 
- The Regional Council may propose to the President of Ukraine to dismiss the Representative from office by the presence of $3 / 4$ votes, that may be supported by the Head of State;

- The Representative of the President of Ukraine in the region has the right to sue local self-government bodies, raise the issue of early termination of powers of local self-government bodies, participate in meetings of local self-government bodies, apply to them with a submission ${ }^{4}$.

The Representative of the President of Ukraine was appointed and dismissed by the Head of State, and also was subordinated to him. The rule of approving the candidate for the Representatives of the President of Ukraine with the respective councils was introduced in the "Regulation on Local State Administrations" by a decree of the President of Ukraine in May 1993. At that time it was determined that the Representatives of the President of Ukraine were appointed and dismissed at the proposal of the Prime Minister of Ukraine ${ }^{5}$.

The essence of the major changes that took place in the system of public authority at the regional level in the early 1990s were reflected not in the Law of Ukraine "On the Representative of the President of Ukraine", but in the Parliament's resolution on its implementation. It stated that the local state administration was "formed on the basis of the executive committees of the respective councils", their structural subdivisions, which were liquidated after the establishment of state administrations. At the time of such a decision (March 5, 1992), the Law of Ukraine "On Local Councils of Deputies and Local and Regional Self-Government" retained a hybrid norm for

${ }^{4}$ Verkhovna Rada of Ukraine (1992), Zakon Ukrajini “Pro Predstavny'ka Prezy'denta Ukrayiny" " [Law of Ukraine "On the Representative of the President of Ukraine"], 05.03.1992, No. 2167-XII, as amended of 05.03.1992, available at https://zakon.rada.gov.ua/laws/show/2167-12/ed19920305, accessed 25 October 2019.

5 President of Ukraine (2001), Ukaz "Pro vnesennya dopovnen' $i$ zmin do punktu 6 Polozhennya pro miscevu derzhavnu administraciyu” [Decree "On amendments to item 6 of the Regulations on local state administration"], 12.05.1993, No. 168/93, available at https://zakon.rada.gov.ua/laws/show/168/93, accessed 25 October 2019. 
councils as "state bodies of local self-government". Namely, it could be formally said that the transfer of power took place from one state institution (though at the same time self-governing) to another one.

The emergence of local state administrations helped to resolve the issue of the essence of councils, which were located in two spaces of public authorities at the same time - in the system of state power and local self-government. On March 26, 1992, the Ukrainian legislation was amended to define the concepts of "local selfgovernment" (its bodies were village, settlement, town and city councils) and "regional self-government" (district and regional councils).

Thus, it can be stated that the assignment of regional councils to the system of local (regional) self-government was preceded by the deprivation of their right to have their own executive bodies, which primarily concerned the implementation of the regional budget and the availability of functions of the budget manager. The oblast councils were seen as exclusively representative bodies.

Due to the introduction of legislative innovations in March 1992, a system of two elements was formed at the regional level. The first element - the state one - was represented by the regional state administration. The second element- local (regional) self-government one - was a regional council without executive bodies. The competences between them were distributed. Both structures were given the tools to influence one another. The regional council could apply to the President of Ukraine for dismissal of the head of the regional state administration, and the latter could ask the parliament to dissolve the corresponding council.

However, such legislative certainty did not last long. The issue of the status of the chairman of the regional council became the object of confrontation between the President of Ukraine and the Verkhovna Rada of Ukraine. Primarily, the position of the Representative of the President of Ukraine - the head of the local state administration, who was deprived of the status of "the highest official of state power" in the region in March 1993, - was adjusted. Then they introduced a rule on the necessity of coordinating the nominations of heads of local state 
administrations with the relevant councils, which were entitled to consider and reject presidential candidates at their plenary sessions ${ }^{6}$. And in parallel, the chairman of the regional council acquired the status of "the highest official in the system of self-government of the region", .

It should be noted that from December 1990 until March 1992 the chairman of the regional council was defined as the "highest official of the region", and then until March 1993 no such characteristics were used for the said official. Changing the status determination of the head of the regional state administration and the chairman of the regional council as the "highest officials" (albeit in their own sphere) was an attempt by the leadership of the Verkhovna Rada of Ukraine to restore power vertically along the line of councils (from the Verkhovna Rada of Ukraine to the village, settlement and city council) and eliminate the presidential vertical.

At the beginning of 1994 , the situation as for the system of local public authorities changed dramatically. According to the Law of Ukraine "On Formation of Local Authorities and Self-Government" of February 3, 1994, the regional councils, which were recognized at that time by the bodies of local self-government, were entrusted with the

${ }^{6}$ Verkhovna Rada of Ukraine (1993), Zakon Ukrajini "Pro vnesennya zmin $i$ dopovnen' do Zakonu Ukrayiny' 'Pro Predstavny'ka Prezy'denta Ukrayiny',” [Law of Ukraine "On Amendments to the Law of Ukraine 'On the Representative of the President of Ukraine"'], 16.03.1993, No. 3066-XII, available at https:// zakon.rada.gov.ua/laws/show/3066-12, accessed 25 October 2019.

${ }^{7}$ Verkhovna Rada of Ukraine (1993), Zakon Ukrajini "Pro vnesennya zmin $i$ dopovnen' do Zakonu Ukrayiny' 'Pro miscevi Rady' narodny'x deputativ ta misceve $i$ regional'ne samovryaduvannya", [Law of Ukraine "On Amendments to the Law of Ukraine 'On Local Councils of People's Deputies and Local and Regional SelfGovernment'”], 16.03.1993, No. 3067-XII, available at https://zakon.rada.gov.ua/ laws/show/3067-12, accessed 25 October 2019.

${ }^{8}$ Verkhovna Rada of the Ukrainian SSR (1990), Zakon Ukrayins'koyi RSR "Pro miscevi Rady' narodny'x deputativ Ukrayins'koyi RSR ta misceve samovryaduvannya" [Law of the Ukrainian SSR "On the Local Soviets of People's Deputies of the Ukrainian SSR and Local Self-Government"], 07.12.1990, No. 533XII as amended of 07.12.1990, available at https://zakon.rada.gov.ua/laws/show/53312/ed19901207, accessed 25 October 2019. 
simultaneous fulfillment of the functions of state authorities ${ }^{9}$. They were subordinate to the Cabinet of Ministers of Ukraine in terms of activities on the exercise of the delegated authorities of the state executive power. Executive committees of the regional councils became the part of regional councils again. Hence, the executive committees of the city and district councils on delegated powers were subordinate to them. The concept of "higher council" reappeared" ${ }^{10}$.

With the advent of executive committees of regional councils, the question of a new approach to determining the status of the Representative of the President of Ukraine and the regional state administration was raised. The use of foreign experience at that time allowed preserving the state element of the system of regional public administration in the form of a purely controlling body (like the French prefect), including the possibility of renaming the position of presidential representative and regional state administration according to their changed role. But the commitment of ideologists of this reform to the idea of "vertical councils" dictated another answer - the elimination of the institutions of the Representative of the President of Ukraine and the regional state administration without the creation of any state authority at the regional level. In June 1994, such adjustments were made according to the proposed scheme. After that, the heads and executive committees of the regional council were entrusted with the performance of the delegated powers of the state executive power ${ }^{11}$.

9 Verkhovna Rada of Ukraine (1994), Zakon Ukrajini "Pro formuvannya miscevy'x organiv vlady' i samovryaduvannya" [Law of Ukraine "On the formation of local authorities and self-government"], 03.02.1994, No. 3917-XII as amended of 03.02.1994, available at https://zakon.rada.gov.ua/laws/show/3917-12, accessed 25 October 2019.

10 Ibid.

11 Verkhovna Rada of Ukraine (1994), Zakon Ukrajini "Pro vnesennya zmin $i$ dopovnen' do Zakonu Ukrayiny' 'Pro formuvannya miscevy'x organiv vlady' $i$ samovryaduvannya" [Law of Ukraine "On Amendments to the Law of Ukraine 'On Formation of Local Authorities and Self-Government'], 28.06.1994, No. 64/94, available at https://zakon.rada.gov.ua/laws/show/en/64/94-вp, accessed 25 October 2019. 
In 1994, a new procedure for the election of the chairmen of regional councils was established, which provided for their direct elections in the territory of the oblast (in a single-mandate constituency) ${ }^{12}$.

Introduced in 1994, the innovations were implemented in the summer of the same year, after which only one authority remained at the regional level - the regional council as a local government body. Its chairman and executive committee were delegated powers of the state executive power. In the new situation, the issue of state influence on the regions was regulated by a decree of the President of Ukraine "On providing the governance of the structures of local executive authorities" of August 6, 1994. According to this decree, the chairmen of regional councils and their executive committees should have understood under the delegated powers of the state authorities the powers, which were provided for in the "Provision on Local State Administrations" of July 24, $1992^{13}$.

This situation took place until June 1995, when according to the Constitutional Treaty between the Verkhovna Rada of Ukraine and the President of Ukraine on the basic principles of organization and functioning of state power and local self-government in Ukraine, a slightly revised model of public authorities organization of the period from 1992 to the first half of 1994 was returned before the adoption of the new Constitution of Ukraine. It was proposed to create regional councils without executive committee as representative bodies of local self-government and regional state administrations as bodies of state executive power led by their heads (without additional definition as a

12 Verkhovna Rada of Ukraine (1994), Zakon Ukrajini "Pro vy'bory' deputativ $i$ goliv sil's 'ky'x, sely'shhny'x, rajonny'x, mis 'ky'x, rajonny'x u mistax, oblasny'x Rad" [Law of Ukraine "On election of deputies and heads of village, settlement, district, city, district in cities, regional councils"], 24.02.1994, No. 3996-XII, available at https://zakon.rada.gov.ua/laws/show/3996-12, accessed 25 October 2019.

${ }^{13}$ President of Ukraine (2001), Ukaz. "Pro zabezpechennya kerivny'cztva strukturamy' derzhavnoyi vy'konavchoyi vlady' na miscyax" [Decree "On providing governance of the structures of local executive authorities"], 06.08.1994, No. 430/94, available at https://zakon.rada.gov.ua/laws/show/ru/430/94, accessed 25 October 2019. 
Representative of the President of Ukraine) ${ }^{14}$. An important innovation in the Constitutional Treaty on June 8, 1995 was that the president was limited in the choice of candidates for the head of the regional state administration. The only way was determined, according to which only the chairman of the regional council was appointed to this position. In order to resolve the acute domestic political crisis, such alignment was introduced. The dismissing from the Head of Regional State Administration position led to the termination of office of the Chairman of Regional Council position ${ }^{15}$.

The process of reforming public authorities at the regional level from Ukraine's independence to the adoption of the new Constitution of Ukraine by the Parliament is shown in Table 1. The chronological frame period determined in accordance with the dates of the adoption of new legislation that changed the previously existing order.

Table 1

Public authorities at the regional level from Ukraine's declaration of independence to the adoption of the Constitution (August 24, 1991 - June 28, 1996)

\begin{tabular}{|c|l|c|}
\hline Period & $\begin{array}{c}\text { Local self- } \\
\text { government body at } \\
\text { the regional level }\end{array}$ & $\begin{array}{c}\text { Executive body at } \\
\text { the regional level }\end{array}$ \\
\hline $\mathbf{1}$ & \multicolumn{1}{|c|}{$\mathbf{2}$} & \multicolumn{3}{|c|}{} \\
\hline $\begin{array}{l}\text { August 1991 }- \\
\text { March 1992 }\end{array}$ & $\begin{array}{l}\text { the regional council } \\
\text { with the executive } \\
\text { committee }\end{array}$ & was absent \\
\hline
\end{tabular}

${ }^{14}$ Verkhovna Rada of Ukraine, President of Ukraine (1995), Konsty'tucijny'j dogovir mizh Verxovnoyu Radoyu Ukrayiny' ta Prezy'dentom Ukrayiny' pro osnovni zasady' organizaciyi ta funkcionuvannya derzhavnoyi vlady' $i$ miscevogo samovryaduvannya $v$ Ukrayini na period do pry'jnyattya novoyi Konsty'tuciyi Ukrayiny' [Constitutional Treaty between the Verkhovna Rada of Ukraine and the President of Ukraine on the Fundamental Principles of Organization and Functioning of State Power and Local Self-Government in Ukraine until the adoption of the New Constitution of Ukraine], 08.06.1995, No. 1к/95-BP, available at https:// zakon.rada.gov.ua/laws/show/1к/95-вр, accessed 25 October 2019.

${ }^{15}$ Ibid. 
End of table 1

\begin{tabular}{|c|c|c|}
\hline 1 & 2 & 3 \\
\hline $\begin{array}{l}\text { March } 1992- \\
\text { February } 1994\end{array}$ & $\begin{array}{l}\text { the regional council } \\
\text { without the executive } \\
\text { committee }\end{array}$ & $\begin{array}{l}\text { the representative of } \\
\text { the President of } \\
\text { Ukraine - the head of } \\
\text { the regional state } \\
\text { administration }\end{array}$ \\
\hline $\begin{array}{l}\text { February } 1994- \\
\text { June } 1995\end{array}$ & $\begin{array}{l}\text { the regional council } \\
\text { with the executive } \\
\text { committee }\end{array}$ & was absent \\
\hline $\begin{array}{l}\text { June } 1995- \\
\text { June } 1996\end{array}$ & $\begin{array}{l}\text { the regional council } \\
\text { without the executive } \\
\text { committee }\end{array}$ & $\begin{array}{ll}\text { regional } & \text { state } \\
\text { administration } & \end{array}$ \\
\hline
\end{tabular}

Predstavny'ka Prezy'denta Ukrayiny', [Law of Ukraine "On the Representative of the President of Ukraine"], 05.03.1992, No. 2167-XII, available at https:// zakon.rada.gov.ua/laws/show/2167-12, Verkhovna Rada of Ukraine (1994), Zakon Ukrajini "Pro formuvannya miscevy'x organiv vlady' $i$ samovryaduvannya" [Law of Ukraine "On the formation of local authorities and self-government"], 03.02.1994, No. 3917-XII as amended of 03.02.1994, available at https://zakon.rada.gov.ua/ laws/show/3917-12, Verkhovna Rada of Ukraine (1996), Konsty'tuciya Ukrayiny' [The Constitution of Ukraine], 28.06.1996, No. 254k/96-вp as amended of 28.06.1996, available at https://zakon.rada.gov.ua/laws/show/254к/96-вp/ed19960628, Verkhovna Rada of Ukraine, President of Ukraine (1995), Konsty'tucijny'j dogovir mizh Verxovnoyu Radoyu Ukrayiny' ta Prezy'dentom Ukrayiny' pro osnovni zasady' organizaciyi ta funkcionuvannya derzhavnoyi vlady' $i$ miscevogo samovryaduvannya $v$ Ukrayini na period do pry'jnyattya novoyi Konsty'tuciyi Ukrayiny' [Constitutional Treaty between the Verkhovna Rada of Ukraine and the President of Ukraine on the Fundamental Principles of Organization and Functioning of State Power and Local Self-Government in Ukraine until the adoption of the New Constitution of Ukraine], 08.06.1995, No. 1к/95-BP, available at https://zakon.rada.gov.ua/laws/show/1 к/95-вp

The peculiarities of determining the status of the heads of public authorities at the regional level are presented in Table 2. 
Table 2

\begin{tabular}{l} 
The heads of public authorities at the regional level \\
from Ukraine's declaration of independence to the adoption of the \\
Constitution (August 24, 1991 - June 28, 1996) \\
\begin{tabular}{|l|l|}
\hline \multicolumn{1}{|c|}{ Period } & \multicolumn{1}{|c|}{ Title } \\
\hline August 1991 - March 1992 & $\begin{array}{l}\text { the chairman of the regional } \\
\text { council (the head of the executive } \\
\text { committee) }\end{array}$ \\
\hline March 1992- February 1994 & $\begin{array}{l}\text { the chairman of the regional } \\
\text { council, the representative of the } \\
\text { President of Ukraine - the head of } \\
\text { the regional state administration }\end{array}$ \\
\hline February 1994- June 1995 & $\begin{array}{l}\text { the chairman of the regional } \\
\text { council (the head of the executive } \\
\text { committee) }\end{array}$ \\
\hline June 1995- June 1996 & $\begin{array}{l}\text { compatibility of the office of the } \\
\text { head of the regional state } \\
\text { administration and the chairman of } \\
\text { the regional council (appointment } \\
\text { of the elected in direct elections the } \\
\text { chairman of the regional council on } \\
\text { the position of the head of the } \\
\text { regional state administration) }\end{array}$ \\
\hline of Ukraine (1992), Zakon Ukrajini "Pro
\end{tabular} \\
\hline
\end{tabular}

Predstavny'ka Prezy'denta Ukrayiny', [Law of Ukraine "On the Representative of the President of Ukraine"], 05.03.1992, No. 2167-XII, available at https:// zakon.rada.gov.ua/laws/show/2167-12, Verkhovna Rada of Ukraine (1994), Zakon Ukrajini "Pro formuvannya miscevy'x organiv vlady' $i$ samovryaduvannya" [Law of Ukraine "On the formation of local authorities and self-government"], 03.02.1994, No. 3917-XII as amended of 03.02.1994, available at https://zakon.rada.gov.ua/laws/ show/3917-12, Verkhovna Rada of Ukraine (1996), Konsty'tuciya Ukrayiny' [The Constitution of Ukraine], 28.06.1996, No. 254k/96-вр as amended of 28.06.1996, available at https://zakon.rada.gov.ua/laws/show/254к/96-вp/ed19960628, Verkhovna Rada of Ukraine, President of Ukraine (1995), Konsty'tucijny'j dogovir mizh Verxovnoyu Radoyu Ukrayiny' ta Prezy'dentom Ukrayiny' pro osnovni zasady' organizaciyi ta funkcionuvannya derzhavnoyi vlady' $i$ miscevogo samovryaduvannya $v$ Ukrayini na period do pry'jnyattya novoyi Konsty'tuciyi Ukrayiny' [Constitutional 
Treaty between the Verkhovna Rada of Ukraine and the President of Ukraine on the Fundamental Principles of Organization and Functioning of State Power and Local Self-Government in Ukraine until the adoption of the New Constitution of Ukraine], 08.06.1995, No. 1к/95-BP, available at https://zakon.rada.gov.ua/laws/show/1к/95-вр

\section{The Ukrainian constitutional model of public authorities at the regional level}

The current model of public management and administration at the regional level was established with the adoption of the Constitution (Fundamental Law) of Ukraine June 28, 1996. Subsequently, the rules specified in the Fundamental Law were consolidated and developed in a number of laws, in particular "On Local Self-Government in Ukraine" and "On Local State Administrations". The period of fluctuations and the lack of clarity on the role of councils and state administrations in the regions ended with the delineation between public authorities and local self-government. But it happened because regional and district councils were denied the right to create executive bodies.

The Constitution of Ukraine established that local state administrations in particular should ensure the following:

- the implementation of national and regional programmes for socio-economic and cultural development, programmes for environmental protection, and also - in places of compact residence of indigenous peoples and national minorities - programmes for their national and cultural development;

- the preparation and implementation of respective region (oblast) and district (rayon) budgets;

- the report on the implementation of respective budgets and $\operatorname{programmes}^{16}$.

Local state administrations were defined as structures that "exercise executive power in oblasts"17. The role of heads of local

16 Verkhovna Rada of Ukraine (1996), Konsty'tuciya Ukrayiny' [The Constitution of Ukraine], 28.06.1996, No. 254k/96-вр as amended of 28.06.1996, available at https://zakon.rada.gov.ua/laws/show/254к/96-вр/ed19960628, accessed 25 October 2019. 
state administrations were especially emphasized as they were entrusted with the formation of the administration. It was established that these officials are appointed to and removed from their office by the President of Ukraine upon the submission of proposal by the Cabinet of Ministers of Ukraine $^{18}$. It is quite clear that the regional state administrations, as public authorities of general competence, could not be limited only to the functions "cut off" from the regional councils. They were primarily responsible for ensuring "the implementation of the Constitution and laws of Ukraine, acts of the President of Ukraine, the Cabinet of Ministers of Ukraine, other executive bodies", "legality and legal order; the observance of laws and freedoms of citizens"19. The Constitution of Ukraine determined that local state administrations shall be "accountable to, and under the control of, councils (radas) in the part of the powers delegated to them by the respective district (rayon) or regional councils" 20 .

The issue of regional councils activity was viewed in terms of they (as well as district councils) were defined as the bodies of local self-government, "representing the common interests of territorial communities of villages, settlements and cities"21. Meanwhile, councils of the basic level were characterized as the bodies of local self-government, through which the territorial community exercises local self-governing ${ }^{22}$. Territorial communities should elect respectively the head of the village, settlement, or city on the basis of universal, equal, and direct suffrage by secret ballot. A village, settlement and city council has the right to form their own executive

17 Ibid.

18 Verkhovna Rada of Ukraine (1996), Konsty'tuciya Ukrayiny' [The Constitution of Ukraine], 28.06.1996, No. 254k/96-вp as amended of 28.06.1996, available at https://zakon.rada.gov.ua/laws/show/254к/96-вp/ed19960628, accessed 25 October 2019.

${ }^{19}$ Ibid.

${ }^{20}$ Ibid.

21 Ibid.

22 Ibid. 
bodies led by a village, settlement, city head. In addition, regional councils had to elect chairmen from among the deputy corps ${ }^{23}$.

The powers of regional councils were as follows:

- approval of programmes for socio-economic and cultural development of the respective oblasts;

- approval of oblast budgets;

- resolve other issues ascribed to their competence by $\operatorname{law}^{24}$.

The absence of executive bodies in regional councils was only partially offset by the introduction of the notion of "executive apparatus of an oblast council", headed by the chairman of the regional council. In the Constitution, this term was not clarified. In the previous time period, this approach was not used. However, in the Law of Ukraine "On local councils of deputies and local and regional authorities" in the amended March 26, 1992 the term "Secretariat of the Council" used for regional councils. The "Secretariat of the Council" was formed for the organizational and technical support of the regional council, its bodies and councilors. But this body, unlike the apparatus of the regional council, was led by the head of the secretariat, appointed by the chairman of the council ${ }^{25}$. The executive apparatus in the regional council was not foreseen up to deny their right to form executive bodies at the constitutional level.

Initially, the executive apparatus of the regional council was to provide organizational, analytical, logistical support to the activity of the council, its bodies, councilors, as well as to facilitate interaction of regional council with territorial communities, local self-government

23 Ibid.

24 Verkhovna Rada of Ukraine (1996), Konsty'tuciya Ukrayiny' [The Constitution of Ukraine], 28.06.1996, No. 254k/96-вр as amended of 28.06.1996, available at https://zakon.rada.gov.ua/laws/show/254к/96-вр/ed19960628, accessed 25 October 2019.

${ }^{25}$ Verkhovna Rada of Ukraine (1990), Zakon Ukrajini "Pro miscevi Rady' narodny'x deputativ ta misceve $i$ regional'ne samovryaduvannya" [Law of Ukraine "On local councils of people's deputies and local self-government"], 07.12.1990, No. 533-XII, with amendments, available at https://zakon.rada.gov.ua/laws/show/53312, accessed 25 October 2019. 
bodies, other structures and representatives of local self-government ${ }^{26}$. In 2010, the possibility of taking measures to monitor the effectiveness of the regulatory acts of this council was added to its powers ${ }^{27}$.

The developers of the existing model of organization of public authority at the regional level in Ukraine have introduced a peculiar mechanism for defining the powers of the regional state administration and the regional council. The Constitution of Ukraine enshrined a provision on the delegation of powers from a regional council to a regional state administration. In Art. 44 of the Law of Ukraine "On Local Self-Government in Ukraine" there is a regulation that "regional councils delegate to the respective state administrations" powers, the list of which amounted to 23 items in May 1997 (as of October 2019, there were 24$)^{28}$.

As it can be seen, the current requirements of the legislation are categorical - the regional council "delegates" the powers to the regional state administration. There is no possibility to discuss the exclusion of all or some of the provisions. That is, the actual consolidation of these powers by the regional state administrations took place, but through a compulsory "delegation" mechanism.

26 Verkhovna Rada of Ukraine (1997), Zakon Ukrajini "Pro misceve samovryaduvannya $v$ Ukrayini" [Law of Ukraine "On local self-government in Ukraine"], 21.05.1997, No. 280/97-вp, available at https://zakon.rada.gov.ua/ laws/show/280/97-вp, accessed 25 October 2019.

${ }^{27}$ Verkhovna Rada of Ukraine (2010), Zakon Ukrajini "Pro vnesennya zmin do deyaky'x zakoniv Ukrayiny' shhodo pry'vedennya yix u vidpovidnist' iz Zakonom Ukrayiny' 'Pro zasady' derzhavnoyi regulyatornoyi polity'ky' u sferi gospodars 'koyi diyal'nosti", [Law of Ukraine "On Amendments to Some Laws of Ukraine on Alignment with the Law of Ukraine 'On Principles of State Regulatory Policy in the Field of Economic Activity"'], 01.07.2010, No. 2388-VI, available at https://zakon.rada.gov.ua/laws/show/2388-17, accessed 25 October 2019.

28 Verkhovna Rada of Ukraine (1997), Zakon Ukrajini "Pro misceve samovryaduvannya $v$ Ukrayini" [Law of Ukraine "On local self-government in Ukraine"], 21.05.1997, No. 280/97-вp, available at https://zakon.rada.gov.ua/ laws/show/280/97-вр, accessed 25 October 2019, Verkhovna Rada of Ukraine (1997), Zakon Ukrajini "Pro misceve samovryaduvannya v Ukrayini" [Law of Ukraine " On local self-government in Ukraine"], 21.05.1997, No. 280/97-вp, as amended of 21.05.1997, available at https://zakon.rada.gov.ua/laws/show/280/97-вp/ed19970521, accessed 25 October 2019. 
Apparently, the authors of the term "delegation" tried in some way to give regional councils the role of the entity delegating authority. In fact, the order established in the legislation puts the regional councils in the position of a local self-government body, from which the state authorities simply withdrew important powers. It would be more accurate to record in the document that the regional state administrations have specified list of powers, and the regional councils simply do not have them. In such an embodiment, the issue of delegation does not arise.

When the Law of Ukraine "On Local State Administrations" was adopted in April 1999, its developers and parliament also used the wording "to exercise the local state administrations powers delegated to them by oblast and rayon councils", devoting to this issue a separate article 29. It simply referred to the provisions of the Constitution of Ukraine and Art. 44 of the Law of Ukraine "On Local SelfGovernment in Ukraine" without any further detail. However, in the Law of Ukraine "On Local State Administrations" on the basis of constitutional norms delegated powers were defined as the own powers of regional administrations. The executive bodies of the regional councils should be the ones to carry out them as their own powers. First of all, it is about the development of projects of regional programmes, the draft of the regional budget and their implementation. At the same time, the Law of Ukraine "On Local State Administrations" emphasized that to carry out the powers delegated by the regional councils "financial, logistical and other resources necessary for their implementation" are transferred to them ${ }^{29}$.

The distribution of powers of regional state administrations and regional councils according to the current constitutional model is shown in Table 3.

${ }^{29}$ Verkhovna Rada of Ukraine (1999), Zakon Ukrajini "Pro miscevi derzhavni administraciyi" [Law of Ukraine "On Local State Administrations"], 09.04.1999, No. 586-XIV, available at https://zakon.rada.gov.ua/laws/show/586-14, accessed 25 October 2019. 
Powers in the area of budgeting and programmes

\begin{tabular}{|l|l|}
\hline Regional state administration & Regional council \\
\hline - preparation of oblast budget; & - approval of oblast budget; \\
- execution of oblast budget; & - supervising the execution of \\
- reporting on the execution of & oblast budget; \\
oblast budget; & - approval of regional \\
- the implementation of & programmes; \\
regional programmes; & - supervising the execution of \\
$-\quad$ reporting on the execution of & regional programmes. \\
regional programmes. & \\
\hline
\end{tabular}

* sources: Verkhovna Rada of Ukraine (1996), Konsty'tuciya Ukrayiny' [The Constitution of Ukraine], 28.06.1996, No. 254k/96-вр as amended of 28.06.1996, available at https://zakon.rada.gov.ua/laws/show/254к/96-вp/ed19960628

Deprivation of regional councils of executive bodies substantially limited the influence of these authorities on the life of the regions. However, not all of their leaders agreed with this situation. They have found some solutions to enhance their relevance and credibility by strengthening the executive apparatus. For example, the Dnipropetrovsk Regional Council approved the structure of its executive apparatus, which generally duplicated the list of branch structural divisions of the regional state administration, creating a total of 16 departments and offices in 2011 (63 posts) ${ }^{30}$ and 18 - in 2016 $(94 \text { posts })^{31}$. In addition, some of the heads of departments and offices

30 Dnipropetrovsk Regional Council (2011), Rishennya "Pro strukturu vy'konavchogo aparatu Dnipropetrovs'koyi oblasnoyi rady", [Decisions "On the structure of the executive apparatus of the Dnipropetrovsk Regional Council'], 25.03.2011, No. 105-5/VI, available at https://dostup.pravda.com.ua/request/ 8642/response/12759/attach/4/img\%20129110758.pdf, accessed 25 October 2019.

31 Dnipropetrovsk Regional Council (2016), Rishennya "Pro strukturu vy'konavchogo aparatu Dnipropetrovs'koyi oblasnoyi rady", [Decisions "On the structure of the executive apparatus of the Dnipropetrovsk Regional Council'], 19.02.2016, No. 12-2/VII, available at https://oblrada.dp.gov.ua/rishennia/sklikannia7/2-session/rishennya-pro-structuru-vikonavchogo-apparaty/, accessed 25 October 2019. 
received the appendix "Deputy Head of the Regional Council for the Executive Apparatus" in the title of their position.

Regional councils began to acquire the status of developers, customers and coordinators of certain regional programmes, and impose on their executive apparatus the coordination of work of their execution. In December 2011, the Dnipropetrovsk Regional Council acted as the developer, the executive, the chief controller of funds for the implementation of tasks and activities of the "Local SelfGovernment Development Programme in Dnipropetrovsk Region for 2012-2016"32.

Efforts of regional councils to gain possibility in the development and implementation of regional programmes was a situation where the executive authorities tried to keep this option only for themselves. Thus, the guidelines for the development of regional programmes approved by the Ministry of Economy of Ukraine in December 2006 determined that the initiator of the program might be as local executive authorities as local self-government. However, the preparation of the draft programme was entrusted only to the regional state administrations alone or jointly with other partners, among whom no regional councils were named ${ }^{33}$. And in June 2007 the Dnipropetrovsk Regional State Administration attributed only its structural units to the initiators of development of the regional programme $^{34}$.

32 Dnipropetrovsk Regional Council (2011), Rishennya "Pro Programu rozvy'tku miscevogo samovryaduvannya u Dnipropetrovs'kij oblasti na 2012 2016 roky", [Decisions "On the local government development programme in Dnepropetrovsk region for 2012-2016"], 27.12.2011, No. 225-10/VI, available at http://212.3.96.115/devel_program, accessed 25 October 2019.

33 Ministry of Economy of Ukraine (2006), Nakaz "Pro zatverdzhennya Metody'chny'x rekomendacij shhodo poryadku rozroblennya regional'ny' $x$ cil'ovy' $x$ program, monitory'ngu ta zvitnosti pro yix vy'konannya" [Order "On approval of the Guidance for the development of regional target programmes, monitoring and reporting on their implementation"], 04.12.2006, No. 367, available at https:// zakon.rada.gov.ua/rada/show/v0367665-06, accessed 25 October 2019.

34 Head of Dnipropetrovsk Regional State Administration (2007), Rozporyadzhennya "Pro poryadok rozroblennya, zatverdzhennya ta vy'konannya regional'ny'x cil'ovy'x program u Dnipropetrovs'kij oblderzhadministracij” [Order 
Another point of tension between the Regional Council and Regional State Administration was the preparation of oblast budget, which provides administration. The Council receives the draft budget for review and subsequent approval usually for a very short period of time. And this leads to resentment among councilors who treats the function of the regional state administration to develop a draft budget as an authority that can be exercised independently in the same way as village, settlement, city councils do. From the point of view of the regional council, this diminishes its identity as a regional public authority.

In times of crisis in Ukraine's political life, certain regional councils, even without the necessary legislative basis, put the issue of executive committees on the agenda. In most cases, these were the demarches of regional power elites addressed to the central government. Thus, in November 2004, dissatisfied with the events of the Orange Revolution, most of the councilors of the Lugansk Regional Council, supporting Prime Minister of Ukraine V. Yanukovych candidacy for the Presidency, called for the creation of their own executive committee ${ }^{35}$ and in late November - early December 2013, dissatisfied with the power of President Viktor Yanukovych, the councilors of the Ternopil and IvanoFrankivsk regional councils decided to form their own executive committees (though as part of the executive apparatus) ${ }^{36}$.

\footnotetext{
"On the Procedure of Development, Approval and Execution of Regional Target Programmes in Dnipropetrovsk Regional State Administrations"], 12.06.2007, No. P-211/0/3-07, available at https://adm.dp.gov.ua/ua/npas/pro-poryadokrozroblennya-zatverdzhennya-ta-vikonannya-regionalnikh-tsilovikh-program-udnipropetrovskiy-f36cc7e82f1a7a4dc225732b00411530, accessed 25 October 2019.

${ }^{35}$ UNIAN (2004), Lugans' $k$ xoche vidokremy'ty's' $i$ shukaye pidtry'mky' $u$ Putina [Lugansk wants to secede and is seeking support from Putin], Ukrayinska Pravda, November 26, available at https://www.pravda.com.ua/news/2004/ 11/26/3004702/, accessed 25 October 2019.

36 Tereshhuk G. (2013), Choty'ry' oblrady' Zaxidnoyi Ukrayiny' xochut' vidibraty' vladu v ODA [Four regional councils of Western Ukraine want to seize power in the RSA], Radio Liberty, December 9, available at https:// www.radiosvoboda.org/a/25194410.html, accessed 25 October 2019.
} 


\section{Main directions of reforming public authorities at the regional level}

Shortly after the adoption of the Constitution of Ukraine, the issue of the absence of executive committees in regional councils became a matter of debate. The Council of Europe did not support the order introduced in 1996. In 2001, the Congress of Local and Regional Authorities called for regional (oblast) councils to have their own executive bodies "further to necessary amendments to the Constitution" ${ }^{37}$. Such a move would be directed on specific implementation of Articles 3.2 and 6.1 of the European Charter of Local Self-Government ${ }^{38}$. The fact is that Ukraine ratified the European Charter of Local Self-Government in full in July 1997, and this imposed obligations on the country.

The model of public administration at the regional level, laid down in the Constitution of Ukraine under the influence of criticism of domestic and foreign experts, has become one of the topics for discussion in the process of reforming public authorities. Already in the first half of the 2000s, proposals emerged to return to an order in which regional councils had their own executive bodies. This issue can only be resolved by amending the Constitution of Ukraine.

The first attempts to amend the regional governance model established by the Constitution of Ukraine were made by a group of members of the parliament in July 2003, proposing in the bill No. 3207-1 to entitle the regional councils to create their own executive bodies. Thus, the function of implementing the programmes of socio-economic and cultural development of the region and its budget should remain with the regional state administrations. As for the regional councils, they should only supervise the execution of these issues. The evident fact is that a partial solution was proposed

37 Congress of local and regional authorities of Europe (2001), Recommendation $102(2001)^{I}$ on local and regional democracy in Ukraine, available at http://www.slg-coe.org.ua/wp-content/uploads/2012/10/Recommendation-10220011-on-local-and-regional-democracy-in-Ukraine.pdf, accessed 25 October 2019.

${ }_{38}$ Council of Europe (1985) European Charter of Local Self-Government, 15.10.1985, available at https://rm.coe.int/168007a088, accessed 25 October 2019. 
and it did not result in the strengthening of regional councils. On the one hand, they should have received the executive body and, on the other hand, the powers necessary for the proper functioning of the regional councils remained with the regional state administrations. In addition, the mentioned deputy bill No. 3207-1 referred to the possibility of delegation of powers from regional councils to regional state administrations ${ }^{39}$.

In 2005, after revision of the draft law No. 3207-1, only the observance of legislation and interaction with local self-government bodies had to be the function of the regional state administrations. Functions for the implementation of regional programmes and the regional budget should have been performed by the regional council ${ }^{40}$.

It took more than five years for the head of state to support this position. Only in March 2009, President of Ukraine V. Yushchenko introduced a draft law of Ukraine "On Amendments to the Constitution of Ukraine" in which he proposed to entitle the regional councils to create executive committees and to exercise all those powers carried out by regional state administrations, as delegated from regional councils. It was intended first to introduce the post of the head of the regional state administration, with an emphasis on this position, rather than on the administration itself as an authority. As it can be seen, the approach used in 1992 when introducing the post of Representative of the President of Ukraine - Head of the Regional State Administration was followed. The head of the regional state administration should perform the following three main functions:

39 Verkhovna Rada of Ukraine (2003), Proekt zakonu Ukrajini "Pro vnesennya zmin do Konsty'tuciyi Ukrayiny", [The draft law of Ukraine “On amendments to the Constitution of Ukraine"'], 01.07.2003, No. 3207-1, available at http://w1.c1.rada.gov.ua/pls/zweb2/webproc4_1?pf3511=15410.3207-1, accessed 25 October 2019.

40 Verkhovna Rada of Ukraine (2005), Postanova "Pro poperednye sxvalennya i napravlennya do Konsty'tucijnogo Sudu Ukrayiny' zakonoproektu pro vnesennya zmin do Konsty'tuciyi Ukrayiny", [Decree “On the preliminary approval and submission to the Constitutional Court of Ukraine of a draft law amending the Constitution of Ukraine"], 23.12.2005, No.3288-IV, available at https:// zakon.rada.gov.ua/laws/show/ru/3288-15, accessed 25 October 2019. 
1) control over the observance of the Constitution of Ukraine and other normative-legal acts by the bodies of executive power and local selfgovernment; 2) ensuring the interaction of territorial units of central executive bodies and local self-government bodies; 3) exercise of other constitutional powers. The head of the regional state administration had to enter the presidential vertical ${ }^{41}$.

The 2009 presidential proposals intended to preserve the old name of the regional state executive body - "regional state administration". However, at the same time its functions changed dramatically. This led to the search for a new name of the new state structures at the regional level. Moreover, such suggestions occured. Thus, Minister of Justice M. Onishchuk, when presenting the Concept of Amendment to the Constitution of April 23, 2008, which was subsequently introduced by the President, proposed to introduce the names "prefecture" and "prefect" to "exercise the representative and controlling functions of the President" $"$.

The transition to practical steps to change the model of public governance at the regional level began after the events of the Euromaidan, officially called the Revolution of Dignity. On April 1, 2014, the Cabinet of Ministers of Ukraine approved the Concept of Reforming Local Self-Government and Territorial Authorities in Ukraine, according to which the regions envisaged the existence of regional councils with executive bodies and regional state administrations. In fact, the aforementioned governmental decision did not raise the issue of the powers of the regional state administrations, although it referred to the "institutional reorganization of local selfgovernment bodies and local executive bodies on a new territorial

41 Verkhovna Rada of Ukraine (2009), Proekt zakonu Ukrajini "Pro vnesennya zmin do Konsty'tuciyi Ukrayiny", [The draft law of Ukraine "On amendments to the Constitution of Ukraine"], 31.03.2009, No. 4290, available at http://w1.c1.rada.gov.ua/pls/zweb2/webproc4_2?pf3516=4290\&skl=7, accessed 25 October 2019.

42 Onishhuk M. V. Doktry'na onovlenoyi Konsty'tuciyi Ukrayiny': realiyi ta perspekty'vy' [The doctrine of the updated Constitution of Ukraine: realities and perspectives], available at https://minjust.gov.ua/m/str_16966, accessed 25 October 2019. 
basis", and the completion of the formation of the relevant legislative framework ${ }^{43}$.

The Verkhovna Rada of Ukraine further elaborated the functions and powers of regional state administrations and regional councils in the draft Law of Ukraine "On Amendments to the Constitution of Ukraine (on Decentralization of Power)" No. 2217a submitted by President P. Poroshenko to Parliament in July 2015 and previously approved on 31 August, 2015. Since then, a new model of regional power has been submitted to society with no alternatives. The presidential document provides for giving the executive power to the prefect (namely the prefect, not the prefecture) in the regions and creating own executive committees in the regional councils. The prefect's powers are to supervise local self-government bodies in observing the Constitution and legislation, to coordinate and supervise the activities of other state authorities in the region, to ensure the implementation of state programmes, and to take measures under martial law or emergency, and in environmental emergency. The new status of the executive power at the regional level in the form of prefect removes from the agenda the need to include a rule of no confidence on the part of the regional council, since no corresponding delegation of powers is envisaged.

The issue of extension of powers of regional councils was solved by introducing the term of "executive committee of the regional council". Nevertheless, the term of "executive bodies" is used for village, settlement and city councils, which, in turn, includes both the executive committee and departments and offices that are engaged in certain areas of policy. The chairman of the village, settlement, city council is in parallel the head of the executive committee of the council, which also includes deputy heads, heads of departments and offices of the relevant council, as well as other persons (heads of

${ }^{43}$ Cabinet of Ministers of Ukraine (2014), Rozporyzdzhennya "Pro sxvalennya Koncepciyi reformuvannya miscevogo samovryaduvannya ta tery'torial 'noyi vlady' $v$ Ukrayini" [The order "On approval of the Concept of reforming local self-government and territorial authority in Ukraine"], 01.04.2014, No. 333-p, available at https://zakon.rada.gov.ua/laws/show/333-2014-p, accessed 25 October 2019. 
enterprises, institutions, organizations, educational institutions, and representatives of public organizations, etc.). The proposed by the President Draft amendments to the Constitution of Ukraine does not answer the questions about the creation of departments, offices and other executive bodies of regional councils.

Another innovation proposed by the head of state was the norm that the regional council, on the one hand, elects the chairman of the council, and on the other hand, appoints and dismisses the head of the executive committee of the council. Such a wording means that the chairman of the regional council and the head of the executive committee of the regional council must (may) be different people ${ }^{44}$.

Innovations on regional councils proposed in presidential draft law No. 2217a in the context of constitutional changes are shown in Table 4.

Table 4

The main features of the regional council as an authority

\begin{tabular}{|l|l|}
\hline \multicolumn{1}{|c|}{$\begin{array}{c}\text { The current Constitution of } \\
\text { Ukraine }\end{array}$} & $\begin{array}{l}\text { Draft Law of Ukraine "On } \\
\text { Amendments to the Constitution of } \\
\text { Ukraine (On Decentralization of } \\
\text { Power)" No. 2217a of July 1, 2015. }\end{array}$ \\
\hline \multicolumn{1}{|c|}{$\mathbf{1}$ the common } \\
\hline $\begin{array}{l}\text { - represents thesents the common interests } \\
\text { interests of territorial communities } \\
\text { of villages, settlements, towns and } \\
\text { cities; } \\
- \text { the chairman is elected by the } \\
\text { council; } \\
- \text { forms the executive apparatus; }\end{array}$ & $\begin{array}{l}\text { of territorial communities of the } \\
\text { region; } \\
- \text { the chairman is elected by the } \\
\text { council; } \\
- \text { forms the executive committee; }\end{array}$ \\
\hline
\end{tabular}

44 Verkhovna Rada of Ukraine (2015), Proekt zakonu Ukrajini “ Pro vnesennya zmin do Konsty'tuciyi Ukrayiny' (shhodo decentralizaciyi vlady')" [The draft law of Ukraine "On amendments to the Constitution of Ukraine (on decentralization of power)"], 01.07.2015, No. 2217a, available at http://w1.c1.rada.gov.ua/pls/zweb2/webproc4_1?pf3511=55812, accessed 25 October 2019. 
End of table 4

\begin{tabular}{|c|c|}
\hline 1 & 2 \\
\hline $\begin{array}{l}\text { - the chairman of the council is } \\
\text { the head of the executive } \\
\text { apparatus. }\end{array}$ & $\begin{array}{l}\text { - the head of the executive } \\
\text { committee set apart from the } \\
\text { chairman of the council; } \\
\text { - the head of the executive } \\
\text { committee is appointed and } \\
\text { dismissed by the council; } \\
\text { - the council forms the executive } \\
\text { committee; } \\
\text { - the head of the executive } \\
\text { committee forms the staff of the } \\
\text { executive committee. }\end{array}$ \\
\hline
\end{tabular}

* sources: Verkhovna Rada of Ukraine (1996), Konsty'tuciya Ukrayiny' [The Constitution of Ukraine], 28.06.1996, No. 254k/96-вp as amended of 28.06.1996, available at https://zakon.rada.gov.ua/laws/show/254к/96-вp/ed19960628, Verkhovna Rada of Ukraine (2015), Proekt zakonu Ukrajini "Pro vnesennya zmin do Konsty'tuciyi Ukrayiny' (shhodo decentralizaciyi vlady')" [The draft law of Ukraine "On amendments to the Constitution of Ukraine (on decentralization of power)"], 01.07.2015, No. 2217a, available at http://w1.c1.rada.gov.ua/pls/zweb2/webproc4_1?p $\mathrm{f} 3511=55812$

The differences between the powers of the regional state administration and the prefect in the context proposed by the President draft law No. 2217a are presented in Table 5.

Having identified the main directions of reforming public authorities at the regional level, Parliament should take the following steps:

- to specify the constitutional provisions on the prefect, the chairman of the regional council, the head of the executive committee of the regional council;

- to determine the status of the prefecture as an authority;

- to clarify the meaning of the term "executive committee of the regional council" in the context of a broad understanding of the concept of "executive bodies of local self-government";

- to elaborate drafts of relevant legislation, which should detail the new model of public administration at the regional level. 
Powers of the executive body of the regional level

\begin{tabular}{|c|c|}
\hline Regional state administration & Prefect \\
\hline $\begin{array}{l}\text { - ensures the execution of the } \\
\text { Constitution and laws of Ukraine, } \\
\text { acts of the President of Ukraine, } \\
\text { acts of the Cabinet of Ministers of } \\
\text { Ukraine and other executive power } \\
\text { bodies; } \\
\text { - ensures legality and legal order; } \\
\text { the observance of rights and } \\
\text { freedoms of citizens; } \\
\text { - implements state and regional } \\
\text { programmes for socio-economic } \\
\text { and cultural development, } \\
\text { programmes for environmental } \\
\text { protection, and, in areas where } \\
\text { indigenous people and national } \\
\text { minorities reside, programmes for } \\
\text { their national and cultural } \\
\text { development; } \\
\text { - prepares and executes regional } \\
\text { budgets; } \\
\text { - reports on the execution of } \\
\text { respective budgets } \\
\text { programmes; and } \\
- \text { interacts with local self- } \\
\text { government bodies; } \\
- \text { realizes other powers vested by } \\
\text { the State and delegated by the } \\
\text { respective councils. }\end{array}$ & $\begin{array}{l}\text { - supervises local self- } \\
\text { government bodies in observing } \\
\text { the Constitution and laws of } \\
\text { Ukraine; } \\
\text { - coordinates the activity of } \\
\text { territorial bodies of central } \\
\text { executive power bodies and } \\
\text { supervises the observance of the } \\
\text { Constitution and laws of Ukraine; } \\
- \text { ensures the implementation of } \\
\text { state programmes; } \\
- \text { directs and organizes the } \\
\text { activity of territorial bodies of } \\
\text { central executive power bodies and } \\
\text { ensures its interaction with local } \\
\text { self-government bodies under } \\
\text { martial law, emergencies or } \\
\text { environmental emergency; } \\
- \text { exercises other powers defined } \\
\text { by the Constitution and laws of } \\
\text { Ukraine. }\end{array}$ \\
\hline
\end{tabular}

* sources: Verkhovna Rada of Ukraine (1996), Konsty'tuciya Ukrayiny' [The Constitution of Ukraine], 28.06.1996, No. 254k/96-вр as amended of 28.06.1996, available at https://zakon.rada.gov.ua/laws/show/254к/96-вp/ed19960628, Verkhovna Rada of Ukraine (2015), Proekt zakonu Ukrajini "Pro vnesennya zmin do Konsty'tuciyi Ukrayiny' (shhodo decentralizaciyi vlady')" [The draft law of Ukraine "On amendments to the Constitution of Ukraine (on decentralization of power)"], 01.07.2015, No. 2217a, available at http://w1.c1.rada.gov.ua/pls/zweb2/webproc4_1?p $\mathrm{f} 3511=55812$ 


\section{CONCLUSIONS}

The question of defining a model of public administration at the regional level was on the agenda in the early 1990s in the context of the democratization of Soviet society and the building of the statehood of an independent Ukraine. The process of dismantling the Soviet governance model, eliminating the verticals of the Soviets, introducing European standards of local self-government, creating executive bodies has begun.

In 1991-1996, initially there was the search for an optimal model for the creation of an element of the presidential vertical in the regions, which was hampered by the parliament's attempt to turn the vertical of the Soviets. With the adoption of the Constitution of Ukraine, the existing model of governance at the regional level was introduced. It envisages the presence of regional councils as representative bodies of local self-government without executive bodies and regional state administrations as executive bodies with delegated functions that can be fulfilled by the regional councils (first of all, the issue of preparation and implementation of the regional budget).

The regional model of public authority organization in Ukraine has been criticized by foreign and domestic experts who consider it advisable to ensure the existence of own executive bodies of regional councils and the refusal of delegation of powers by regional councils to regional state administrations. The various reform options were identified from 2003 to 2015 through the parliamentary and presidential initiatives.

In 2015, the process of introducing a new model that provides the functioning of the prefect as an institution of regional executive power with supervisory powers and regional councils with executive committees and powers, which does not need to be delegated to the executive, began. This approach generally creates conditions for local self-government strengthening at the regional level and improving the system of checks and balances between different forms of public authority. It is important to overcome the inhibitory factors and provide the necessary constitutional changes. At the same time, there 
is a need to specify the general provisions, preparation and adoption of a new legislation.

\section{SUMMARY}

The article deals with problem of the functioning and reforming of Ukrainian public authorities' model at the regional level. The core question is about powers of the state and local self-government bodies, the delineation and delegation of their functions. Regional (oblast) state administrations and regional (oblast) councils are in unbalanced situation now. The history, current situation and perspectives for implementation of a new division of competences between the administration and the council have been investigated. In early 1990, state administrations were formed by way of removing the executive bodies from councils. Modern Ukrainian regional public authorities' model is based on the concept of the delegation of powers from regional (oblast) councils to regional (oblast) state administrations that have limited opportunities of local self-government. The article concludes that the essence of problem is the execution of regional (oblast) budget and programmes that have been cut off from the councils. The conflict resolution proposes both the establishment of executive bodies of oblast councils and the proper changing oblast administration (prefect) status to supervision authority as the aim of future constitutional reform in the decentralization sphere.

\section{REFERENCES}

1. Cabinet of Ministers of Ukraine (2014), Rozporyzdzhennya "Pro sxvalennya Koncepciyi reformuvannya miscevogo samovryaduvannya ta tery'torial'noyi vlady' v Ukrayini” [The order "On approval of the Concept of reforming local self-government and territorial authority in Ukraine"], 01.04.2014, No. 333-p, available at https://zakon.rada.gov.ua/laws/show/333-2014-p, accessed 25 October 2019.

2. Congress of local and regional authorities of Europe (2001), Recommendation $102(2001)^{1}$ on local and regional democracy in Ukraine, available at http://www.slg-coe.org.ua/wp- 
content/uploads/2012/10/Recommendation-102-20011-on-local-andregional-democracy-in-Ukraine.pdf, accessed 25 October 2019.

3. Council of Europe (1985) European Charter of Local SelfGovernment, 15.10.1985, available at https://rm.coe.int/168007a088, accessed 25 October 2019.

4. Dnipropetrovsk Regional Council (2011), Rishennya "Pro Programu rozvy'tku miscevogo samovryaduvannya $u$ Dnipropetrovs 'kij oblasti na 2012 - 2016 roky", [Decisions "On the local government development programme in Dnepropetrovsk region for 2012-2016"], 27.12.2011, No. 225-10/VI, available at http://212.3.96.115/devel_program, accessed 25 October 2019.

5. Dnipropetrovsk Regional Council (2011), Rishennya "Pro strukturu vy'konavchogo aparatu Dnipropetrovs'koyi oblasnoyi rady"' [Decisions "On the structure of the executive apparatus of the Dnipropetrovsk Regional Council"'], 25.03.2011, No. 105-5/VI, available at https://dostup.pravda.com.ua/request/8642/response/ 12759/attach/4/img\%20129110758.pdf, accessed 25 October 2019.

6. Dnipropetrovsk Regional Council (2016), Rishennya "Pro strukturu vy'konavchogo aparatu Dnipropetrovs'koyi oblasnoyi rady"' [Decisions "On the structure of the executive apparatus of the Dnipropetrovsk Regional Council'], 19.02.2016, No. 12-2/VII, available at https://oblrada.dp.gov.ua/rishennia/sklikannia-7/2-session/ rishennya-pro-structuru-vikonavchogo-apparaty/, accessed 25 October 2019.

7. Head of Dnipropetrovsk Regional State Administration (2007), Rozporyadzhennya "Pro poryadok rozroblennya, zatverdzhennya ta vy'konannya regional'ny'x cil'ovy'x program $u$ Dnipropetrovs 'kij oblderzhadministracij" [Order "On the Procedure of Development, Approval and Execution of Regional Target Programmes in Dnipropetrovsk Regional State Administrations"], 12.06.2007, No. P-211/0/3-07, available at https://adm.dp.gov.ua/ua/ npas/pro-poryadok-rozroblennya-zatverdzhennya-ta-vikonannya-regio nalnikh-tsilovikh-program-u-dnipropetrovskiy-f36cc7e82f1a7a4dc22 5732b00411530, accessed 25 October 2019. 
8. Ministry of Economy of Ukraine (2006), Nakaz "Pro zatverdzhennya Metody'chny'x rekomendacij shhodo poryadku rozroblennya regional'ny'x cil'ovy'x program, monitory'ngu ta zvitnosti pro yix vy'konannya" [Order "On approval of the Guidance for the development of regional target programmes, monitoring and reporting on their implementation"], 04.12.2006, No. 367, available at https://zakon.rada.gov.ua/rada/show/v0367665-06,

accessed 25 October 2019.

9. Onishhuk M. V. Doktry'na onovlenoyi Konsty'tuciyi Ukrayiny': realiyi ta perspekty'vy' [The doctrine of the updated Constitution of Ukraine: realities and perspectives], available at https://minjust.gov.ua/m/str_16966, accessed 25 October 2019.

10. President of Ukraine (2001), Ukaz "Pro Polozhennya pro miscevu derzhavnu administraciyu" [Decree "On the Regulations on Local State Administration"], 14.04.1992, No. 252, available at https://zakon.rada.gov.ua/laws/show/ru/252/92, accessed 25 October 2019.

11. President of Ukraine (2001), Ukaz "Pro vnesennya dopovnen' $i$ zmin do punktu 6 Polozhennya pro miscevu derzhavnu administraciyu" [Decree "On amendments to item 6 of the Regulations on local state administration"], 12.05.1993, No. 168/93, available at https://zakon.rada.gov.ua/laws/show/168/93, accessed 25 October 2019.

12. President of Ukraine (2001), Ukaz "Pro zabezpechennya kerivny'cztva strukturamy' derzhavnoyi vy'konavchoyi vlady' na miscyax" [Decree "On providing governance of the structures of local executive authorities"], 06.08.1994, No.430/94, available at https://zakon.rada.gov.ua/laws/show/ru/430/94, accessed 25 October 2019.

13. Tereshhuk G. (2013), Choty'ry' oblrady' Zaxidnoyi Ukrayiny' xochut' vidibraty' vladu $v$ ODA [Four regional councils of Western Ukraine want to seize power in the RSA], Radio Liberty, December 9, available at https://www.radiosvoboda.org/a/251944 10.html, accessed 25 October 2019. 
14. UNIAN (2004), Lugans'k xoche vidokremy'ty's' $i$ shukaye pidtry'mky' u Putina [Lugansk wants to secede and is seeking support from Putin], Ukrayinska Pravda, November 26, available at https://www.pravda.com.ua/news/2004/11/26/3004702/, accessed 25 October 2019.

15. Verkhovna Rada of the Ukrainian SSR (1990), Zakon Ukrayins'koyi RSR 'Pro miscevi Rady' narodny'x deputativ Ukrayins'koyi RSR ta misceve samovryaduvannya" [Law of the Ukrainian SSR "On the Local Soviets of People's Deputies of the Ukrainian SSR and Local Self-Government”], 07.12.1990, No. 533XII as amended of 07.12.1990, available at https://zakon.rada.gov.ua/ laws/show/533-12/ed19901207, accessed 25 October 2019.

16. Verkhovna Rada of Ukraine (1990), Zakon Ukrajini "Pro miscevi Rady' narodny'x deputativ ta misceve $i$ regional'ne samovryaduvannya" [Law of Ukraine "On local councils of people's deputies and local self-government"], 07.12.1990, No. 533-XII, with amendments, available at https://zakon.rada.gov.ua/laws/show/533-12, accessed 25 October 2019.

17. Verkhovna Rada of Ukraine (1992), Zakon Ukrajini "Pro Predstavny'ka Prezy'denta Ukrayiny'” [Law of Ukraine 'On the Representative of the President of Ukraine"], 05.03.1992, No. 2167XII, available at https://zakon.rada.gov.ua/laws/show/2167-12, accessed 25 October 2019.

18. Verkhovna Rada of Ukraine (1992), Zakon Ukrajini "Pro Predstavny'ka Prezy'denta Ukrayiny'” [Law of Ukraine 'On the Representative of the President of Ukraine"], 05.03.1992, No. 2167XII, as amended of 05.03.1992, available at https://zakon.rada.gov.ua/ laws/show/2167-12/ed19920305, accessed 25 October 2019.

19. Verkhovna Rada of Ukraine (1993), Zakon Ukrajini "Pro vnesennya zmin i dopovnen' do Zakonu Ukrayiny' 'Pro miscevi Rady' narodny'x deputativ ta misceve $i$ regional'ne samovryaduvannya", [Law of Ukraine "On Amendments to the Law of Ukraine 'On Local Councils of People's Deputies and Local and Regional SelfGovernment"'], 16.03.1993, No. 3067-XII, available at https:// zakon.rada.gov.ua/laws/show/3067-12, accessed 25 October 2019. 
20. Verkhovna Rada of Ukraine (1993), Zakon Ukrajini "Pro vnesennya zmin i dopovnen' do Zakonu Ukrayiny' 'Pro Predstavny'ka Prezy'denta Ukrayiny"," [Law of Ukraine "On Amendments to the Law of Ukraine 'On the Representative of the President of Ukraine"'], 16.03.1993, No. 3066-XII, available at https://zakon.rada.gov.ua/ laws/show/3066-12, accessed 25 October 2019.

21. Verkhovna Rada of Ukraine (1994), Zakon Ukrajini "Pro formuvannya miscevy'x organiv vlady' i samovryaduvannya” [Law of Ukraine "On the formation of local authorities and self-government"], 03.02.1994, No. 3917-XII as amended of 03.02.1994, available at https://zakon.rada.gov.ua/laws/show/3917-12, accessed 25 October 2019.

22. Verkhovna Rada of Ukraine (1994), Zakon Ukrajini "Pro vnesennya zmin i dopovnen' do Zakonu Ukrayiny' 'Pro formuvannya miscevy'x organiv vlady' $i$ samovryaduvannya" [Law of Ukraine "On Amendments to the Law of Ukraine 'On Formation of Local Authorities and Self-Government"], 28.06.1994, No. 64/94, available at https://zakon.rada.gov.ua/laws/show/en/64/94-вp, accessed 25 October 2019.

23. Verkhovna Rada of Ukraine (1994), Zakon Ukrajini "Pro vy'bory' deputativ $i$ goliv sil's 'ky'x, sely'shhny'x, rajonny'x, mis 'ky'x, rajonny'x u mistax, oblasny'x Rad" [Law of Ukraine "On election of deputies and heads of village, settlement, district, city, district in cities, regional councils"], 24.02.1994, No. 3996-XII, available at https://zakon.rada.gov.ua/laws/show/3996-12, accessed 25 October 2019.

24. Verkhovna Rada of Ukraine (1996), Konsty'tuciya Ukrayiny' [The Constitution of Ukraine], 28.06.1996, No. 254k/96-вp as amended of 28.06.1996, available at https://zakon.rada.gov.ua/ laws/show/254к/96-вр/ed19960628, accessed 25 October 2019.

25. Verkhovna Rada of Ukraine (1997), Zakon Ukrajini "Pro misceve samovryaduvannya $v$ Ukrayini" [Law of Ukraine "On local self-government in Ukraine”], 21.05.1997, No. 280/97-вp, available at https://zakon.rada.gov.ua/laws/show/280/97-вp, accessed 25 October 2019. 
26. Verkhovna Rada of Ukraine (1997), Zakon Ukrajini "Pro misceve samovryaduvannya v Ukrayini" [Law of Ukraine " On local self-government in Ukraine"], 21.05.1997, No. 280/97-вp, as amended of 21.05.1997, available at https://zakon.rada.gov.ua/laws/show/ 280/97-вр/ed19970521, accessed 25 October 2019.

27. Verkhovna Rada of Ukraine (1999), Zakon Ukrajini "Pro miscevi derzhavni administraciyi" [Law of Ukraine "On Local State Administrations"], 09.04.1999, No. 586-XIV, available at https:// zakon.rada.gov.ua/laws/show/586-14, accessed 25 October 2019.

28. Verkhovna Rada of Ukraine (2003), Proekt zakonu Ukrajini "Pro vnesennya zmin do Konsty'tuciyi Ukrayiny", [The draft law of Ukraine "On amendments to the Constitution of Ukraine"], 01.07.2003, No. 3207-1, available at http://w1.c1.rada.gov.ua/pls/ zweb2/webproc4_1?pf3511=15410.3207-1, accessed 25 October 2019.

29. Verkhovna Rada of Ukraine (2005), Postanova "Pro poperednye sxvalennya $i$ napravlennya do Konsty'tucijnogo Sudu Ukrayiny' zakonoproektu pro vnesennya zmin do Konsty'tuciyi Ukrayiny", [Decree "On the preliminary approval and submission to the Constitutional Court of Ukraine of a draft law amending the Constitution of Ukraine"'], 23.12.2005, No. 3288-IV, available at https://zakon.rada.gov.ua/laws/show/ru/3288-15, accessed 25 October 2019.

30. Verkhovna Rada of Ukraine (2009), Proekt zakonu Ukrajini "Pro vnesennya zmin do Konsty'tuciyi Ukrayiny", [The draft law of Ukraine "On amendments to the Constitution of Ukraine"], 31.03.2009, No. 4290, available at http://w1.c1.rada.gov.ua/pls/zweb2/ webproc4_2?pf3516=4290\&skl=7, accessed 25 October 2019.

31. Verkhovna Rada of Ukraine (2010), Zakon Ukrajini "Pro vnesennya zmin do deyaky'x zakoniv Ukrayiny' shhodo pry'vedennya yix u vidpovidnist' iz Zakonom Ukrayiny' 'Pro zasady' derzhavnoyi regulyatornoyi polity'ky' u sferi gospodars 'koyi diyal'nosti', "Law of Ukraine "On Amendments to Some Laws of Ukraine on Alignment with the Law of Ukraine 'On Principles of State Regulatory Policy in the Field of Economic Activity"'], 01.07.2010, No. 2388-VI, available 
at https://zakon.rada.gov.ua/laws/show/2388-17, accessed 25 October 2019.

32. Verkhovna Rada of Ukraine (2015), Proekt zakonu Ukrajini “ Pro vnesennya zmin do Konsty'tuciyi Ukrayiny” (shhodo decentralizaciyi vlady')" [The draft law of Ukraine "On amendments to the Constitution of Ukraine (on decentralization of power)"], 01.07.2015, No. 2217a, available at http://w1.c1.rada.gov.ua/pls/ zweb2/webproc4_1?pf3511=55812, accessed 25 October 2019.

33. Verkhovna Rada of Ukraine, President of Ukraine (1995), Konsty'tucijny'j dogovir mizh Verxovnoyu Radoyu Ukrayiny' ta Prezy'dentom Ukrayiny' pro osnovni zasady' organizaciyi ta funkcionuvannya derzhavnoyi vlady' $i$ miscevogo samovryaduvannya $v$ Ukrayini na period do pry'jnyattya novoyi Konsty'tuciyi Ukrayiny' [Constitutional Treaty between the Verkhovna Rada of Ukraine and the President of Ukraine on the Fundamental Principles of Organization and Functioning of State Power and Local SelfGovernment in Ukraine until the adoption of the New Constitution of Ukraine], 08.06.1995, No. 1к/95-BP, available at https:// zakon.rada.gov.ua/laws/show/1к/95-вр, accessed 25 October 2019.

\section{Information about the author:} Yevhenii Borodin,

Doctor of Science in History, Professor,

Professor in Public Administration and Local Self-Government Department, First Deputy Director of Dnipropetrovs'k Regional Institute for Public Administration, National Academy for Public Administration under the President of Ukraine 29, Gogol str., Dnipro, 49044, Ukraine ORCID ID: orcid.org/0000-0002-7331-5981 
DOI https://doi.org/10.36059/978-966-397-162-9/88-115

\section{THE STRUCTURAL ANALYSIS \\ OF THE INVESTMENT MECHANISMS OFTHE PUBLIC POLICYINTHE SOCIAL DEVELOPMENT}

\section{Oksana Marukhlenko}

\section{INTRODUCTION}

According to Art. 1 of the Ukrainian Constitution, Ukraine is a social state. Prioritized principles of such a state include the public welfare and development. In general, the level of the population wellbeing is determined by the volume and structure of the consumption, the totality of the current incomes and savings, the provision of the living conditions etc. It serves as one of the important characteristics of theliving conditions for the population and its social protection. The studies show the close link between the social development tothe growth rates and social protection strategies.

According to Art.11 of the Law of Ukraine dated 1 July 2010 No. 2411-VI "On the Foundations of Domestic and Foreign Policy", it is determined that one of the main tasks of the state policy is to ensure the improvement of the people well-beingwith a focus onthe full economic development and integration of the Ukrainian economy into the world economic system. Thus, raising the level of the social development is an urgent task of both economic and social policy of the Ukrainian state. It actualizes the need to understand the issues of the formation, application and evaluation of the investment mechanisms effectiveness inthe public policy by ensuring the social development.

\section{The content of the concept "administration mechanism"}

The basic element of the term "the investment mechanism of the public policy " is the concept of the mechanism itself. Mechanisms are different in design and purpose, forming the basis of most machines, appliances and devices. In economics, the term "mechanism" is used 
figuratively and means "an internal structure, the system of something." Most likely this term is borrowed from the natural and technical sciences. "Mechanism" in Greek is translated as "a weapon, a machine" and nowadaysit has the following essential meanings:

1. The device for transmitting and converting movements in which the movement of one or more elements causes certain movements of the rest.

2. An internal device, an internal structure of the machine, an equipment.

3. The set of states and processes that make up any physical, chemical, physiological, economic, and psychological phenomenon.

4. The system, device, method that determine the order of a particular activity ${ }^{1}$. The mechanism of the public policy is a complex management category.

In general, all available management mechanisms can be divided into three types: the mechanisms as tools, the mechanisms as systems (the set of interconnected elements), and the mechanisms as processes (the sequence of certain transformations).

The mechanism of the public administration is the mechanism as a system intended for the practical implementation of the public administration and the achievement of the set goals, which has the defined structure, methods, levers, instruments of the influence on the object of the management with the appropriate legal, regulatory and information support (Fig. 1).

However, the composition of the public administration mechanism for a particular area of the social development will change, depending on the specific nature of the particular area.

Inpublic administration there are different approaches to the types and classification of the public administration mechanisms. We agree with N. Bryukhovetska's opinion that "the administration mechanism will have its own name according to the focal points in

${ }^{1}$ DiNitto D. M. (2003) Social Welfare: Politics and Public Policy. Boston: Pearson Education. 450 p. 
certain spheres of management"2. Depending on the problems and the ways they are solved with the use of the specific administration mechanism, it can be complex and include several separate mechanisms.

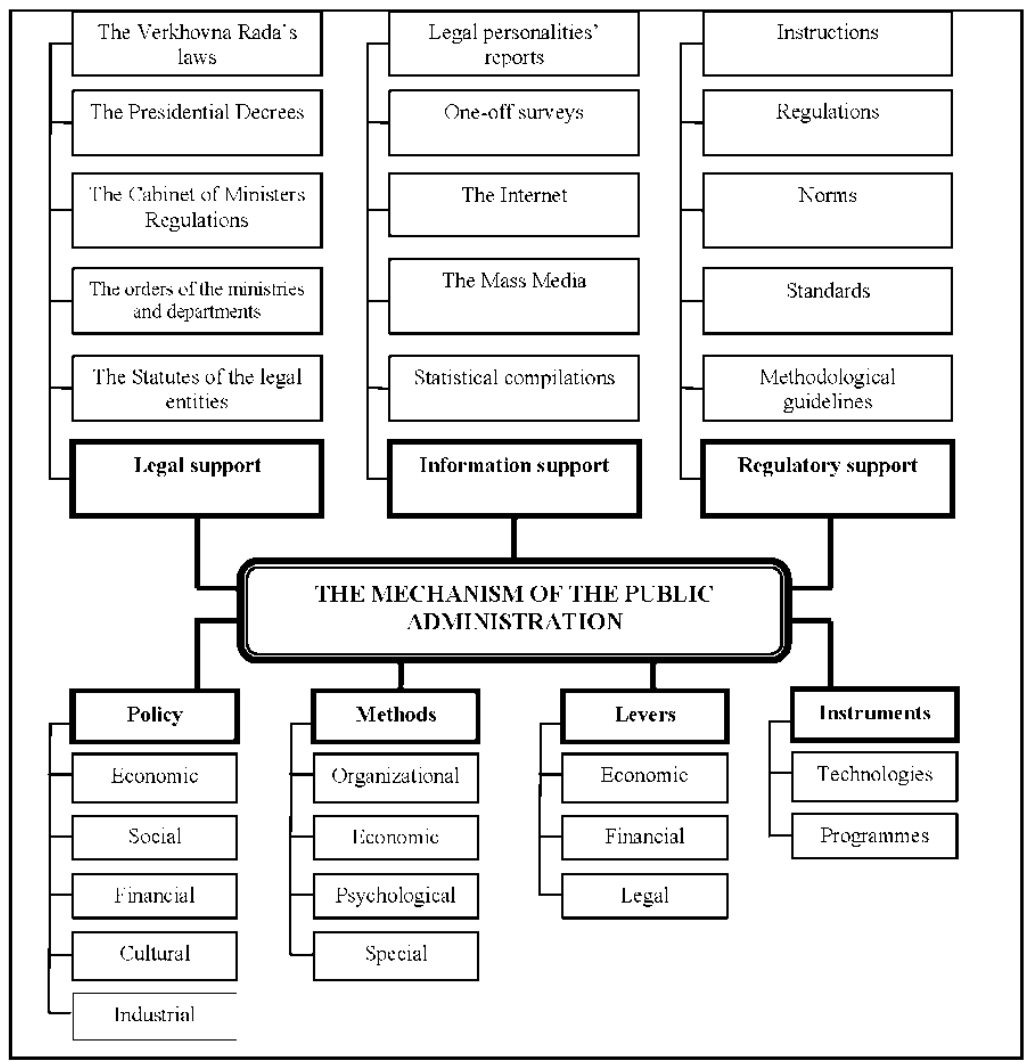

Fig. 1. The structure of the public administration mechanism ${ }^{3}$

${ }^{2}$ Yuzkov L.P (1993) Ghosudarstvennoe upravlenye v polytycheskoj systeme razvytogho socyalyzma [Public administration in the political system of the advanced socialism]. Kyiv. (in Ukrainian)

${ }^{3}$ Yuzkov L.P (1993) Ghosudarstvennoe upravlenye v polytycheskoj systeme razvytogho socyalyzma [Public administration in the political system of the advanced socialism]. Kyiv. (in Ukrainian) 
The complex mechanism of the public administration may consist of the following types of mechanisms:

- economic (the mechanisms of the public administrationin banking, financial activities, investment operations, innovation activities, credit operations, taxation, insurance business etc.);

- motivational (the set of the command-administrative and socio-economic incentives that encourage public officials to work effectively);

- organizational (the objects and subjects of the public administration, their goals, tasks, functions, management methods and organizational structures, as well as the results of their functioning);

- political (the mechanisms of the economic, social, financial, industrial policy formation etc.);

- legal (the legal and regulatory support: the laws and regulations of the Verkhovna Rada of Ukraine (hereinafter VRU), the decrees of the President, the resolutions and orders of the Cabinet of Ministers of Ukraine (hereinafter CMU), as well as the methodological recommendations and instructions etc.).

It should be noted that in addition to the comprehensive mechanism of the public administration, there are also non-state mechanisms of management, namely business, confessional, corruption, party etc.

O. Korotych distinguishes the classification of the public administration mechanisms based on the subjects of management ${ }^{4}$. According to this feature, in Ukraine the mechanisms of the public administration are divided into those implemented by governing bodies:

- at the highest level (VRU, President, CMU);

- at the regional level (the regional councils, the regional state administrations (hereinafter RSA));

4 Bryukhovetska N.Yu. (1999) Ekonomichnyj mekhanizm pidpryjemstva $v$ rynkovij ekonomici: metodologhija $i$ praktyka [The economic mechanism of an enterprise in the market economy: methodology and practice]. Donetsk: IEP NAN of Ukraine. (in Ukrainian) 
- at the district level (the district councils, the district state administrations);

- at the local level (the city, town, village councils).

The generalized classification of the public administration mechanisms is presented in Fig. 2.

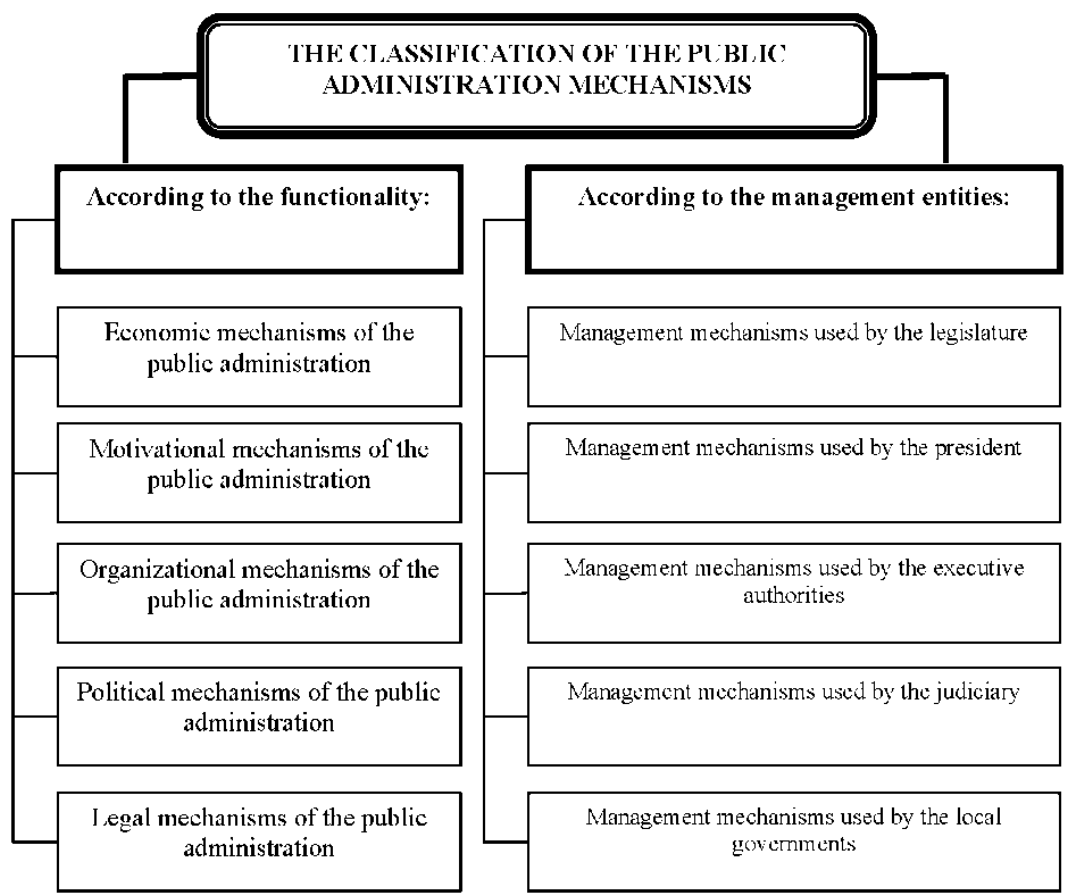

Fig. 2. The classification of the public administration mechanisms

It includes the devision of the public administration mechanisms according to their functions andmanagement entities.

The question of the mechanisms is one of the central issues concerningthe state regulation of any public processes. The scientific literature on public administration offers various approaches to the understanding the nature and functionality of the state and public administration mechanisms. In that regard, the Ukrainian researcher T. Butyrska believes that in public administration not every decision 
can be considered as the mechanism of the management, but only the decision that is subordinated to the logic of the development.The management of this development involves the constant formation of the picture for the future, the formation of the ideas, the implementation of which coincides with the practical solution of the problems ${ }^{5}$.

H. Atamanchuk emphasizes the institutional nature of the public administration mechanisms understanding under them the complex system of the state bodies organized in accordance with certain principles for carrying out the tasks of the public administration. Within this approach, the mechanism of the public administration is perceived as a "tool" for the implementation of the executive power of the state aimed at fulfilling certain functions ${ }^{6}$. Considering the mechanisms of the public administration in the social sphere (on the example of the social protection for disabled people), K. Mishchenko proposes to identify programme-targeted, organizationaladministrative, economic, social-psychological and administrative mechanisms. Their tasks are to perform the regulatory, coordinating, motivational and other functions.

The systematic approach to the understanding of the public administration mechanisms is demonstrated by R. Rudnytska, O. Sydorchuk and O. Stelmakh, who believe that such mechanisms are an "artificially created complex system designed to achieve set goals, which has a defined structure, the set of the legal norms, methods, means, instruments of the state influence on the object" "7. And when it

5 Korotych O.B. (2006) Derzhavne upravlinnja reghionaljnym rozvytkom Ukrajiny [The public administration of the regional development of Ukraine]. Kharkiv. (in Ukrainian)

6 Astapova H.V. Astapova Ey.A., Loiko D.P. (2001) Orghanyzacyonnoekonomycheskyj mekhanyzm korporatyvnogho upravlenyja $v$ sovremennykh uslovyjakh reformyrovanyja ekonomyky Ukrayny [The Organizational and economic mechanism of the corporate governance in the current conditions of reforming the Ukrainian economy]. Donetsk. (in Ukrainian)

Kovaluk O.M. (2002) Finansovyj mekhanizm orghanizaciji ekonomiky Ukrajiny (problemy teoriji i praktyky) [The financial mechanism of the organization of 
comes to the system, it is important to take into account its properties such as the presence of the subsystems that are dynamically interacting, the presence of "logging out" in the form of the made state decisions, the feedback, synergetic effects etc.

The Ukrainian scientist V. Bakumenko emphasizes the process of the management which, by his definition, is the interaction of the subject (the management system) and the object (the system which is governed). The management entity in the communication process acts on the management object through certain managerial influences. They should trigger an action (event) in the management object. Such actions should change the environment in the direction desired for the subject. In this case, the management object manifests itself inthe actions which are the result of the economic, political, and social activities. In this way, the subject and object of the management are in the constant dynamic interaction. However, the managed object is by no means passive; it actively participates in the formation of the nature and direction of the managerial influence, which is covered by such a concept as the "feedback".

Within the structural approach, the management mechanism is considered as the lower level of the system hierarchy in relation to the administration system. This mechanism should consist of the set of certain parts, that is, have an internal structure. The most common requirement for the structural elements of the management mechanism is to determine its structure, that is, the justification of the necessary and sufficient composition of its components. For each of the substantiated and selected components of the management mechanism it is necessary to determine the essence, results and functions.

Summarizing the functional, structural approaches and the understanding of the public administrationmechanisms I. Cherlenyak

the Ukrainian Economy (The problems of the theory and practice)]. Lviv. (in Ukrainian)

8 Yeremenko-Hryhorenko O.A. (1999) Orghanyzacyonno-ekonomycheskyj mekhanyzm upravlenyja khozjajstvennoj dejateljnostjju predpryjatyja [The organizational and economic mechanism of the management inthe economic activity of the enterprise]. Donetsk. (in Ukrainian) 
emphasizes that the management mechanism must unite the management entity, the management object, management goals and conditions based on the certain autonomous principle of coordination and organization. The author divides the mechanisms into two large groups:

- general mechanisms are the set of autonomously coordinated links between the structure, functions for the structures of the state power and the structure, the functions of the society structures and the structures of the economy to ensure the process of the socio-economic reproduction and the comprehensive development of the state. Autonomous coordination is ensured by the system of the constitutional and administrative law, the autonomy of the economic system, the traditions of the human and citizen rights protection;

- special mechanisms are the groups of coordinated relations between the functions of the special state body or institution and the functions for the structures of the economy and society, that is, the interaction coordinated by the legal system and conditions of the socio-political and socio-economic development, between the decision-making process and the processes of their implementation and evaluation; the financial, economic, investment, legal, motivational mechanisms of the public administration ${ }^{9}$.

Thus, when considering the mechanisms of the public administration for the social development, we should first of all pay attention to the general guidelines of the management system, that reflect its most significant characteristics, which follow from the theory and methodology of the public administration. The complexity of the forming, applying and evaluating the public management mechanisms in the social development lies in the ambiguity of the understanding the essence of the concept "social development". Within the conventional view of the social development as the well-

9 Amosov A.Yu. (2001) Peretvorennja mekhanizmiv derzhavnogho reghuljuvannja ekonomichnogho rozvytku [The transformation of the mechanisms of the state regulation for the economic development]. The public administration and local self-government, vol. 2, pp. 10-16. 
being of the population and its interpretation through the categories of needs and benefits, the indicators of the social development are:

- per capita income level, the provision of the material and technical resources to households;

- the level of the population differentiation according to their income and consumption;

- the cost of living;

- the absolute and relative poverty;

- the standard of living (the standard of consumption).

Thus, the social development is directly related to the concept of the population well-being and it determines the absolute and relative level of providing the needs of the person (family) by tangible and intangiblebenefits, in particular spiritual, in comparison with the standards and norms adopted in a particular society or social group, as well as compared to the international standards.

The international regulatory legal acts, to which Ukraine acceded and ratified in due course, and which, in their turn, according to the international law have a higher legal force in comparison with the Ukrainian legislation, play an important role in establishing the management goals for public welfare. According to Art. 25 of the Universal Declaration of Human Rights (1948), it is stated that everyone has the right to the standard of living (including food, clothing, housing, medical care and necessary social services) that is necessary to maintain the health and well-being of any person and a family. The European Social Charter (1961) proclaimed the human right to social progress.

At the same time, in the post-industrial society, which is characterized by the transition to the knowledge economy, a special emphasis is placed on human capabilities, the development of the creative and intellectual potential. Therefore, the human dimension that includes education, science, culture, information technology, spirituality, which determine the quality of life,becomes the core of the modern social system.According to the American philosopher D. Bell, "an industrial society is determined by the quantity of goods, which testifies to the standard of living, whereas a post-industrial society is 
determined by the quality of life, measured by services and amenities, namely health care, education, recreation, arts development ... " ${ }^{\prime 10}$. This is about the social development, which components, according to I. Horhes, O. Petroye, V. Skurativsky, P. Sytnyk, V. Troschinsky ${ }^{11}$ are as follows:

- the development of the humanitarian sphere (health care, education, science), as well as the humanitarian policy for the development of cultural institutions and infrastructure;

- the implementation of the state policy in the sphere of the religious life;

- the development of the social sphere (social relations, payment and safety for labour, social partnership and social dialogue);

- providing social security (social protection, social insurance, social assistance, social work).

It is social development that forms the basis for achieving the well-being of the population.

With regard to the transformation of the views on the population well-being, the question arises as to the goals and objectives of the public welfare policy and the general guidelines of the managed system. According to the American researcher D. DiNitto, the public welfare policies include a number of policy issues (measures) for the poor, those who are atrisk to become poor and the rich. The boundaries of such a policy are vague. It is therefore viewed in a broad and narrow sense. In broad terms, such policies cover almost all the public policy measures, from taxation, national defense and energy conservation to health care, housing and social assistance programmes. In a narrow sense, it is a state policy that directly affects citizens' incomes, services and opportunities for the socially vulnerable groups

${ }^{10}$ Obolensky O. (1998) Derzhavna sluzhba Ukrajiny: realizacija systemnykh poghljadiv shhodo orghanizaciji ta funkcionuvannja [State Service of Ukraine: Implementation of Systematic Views on Organization and Functioning]. Khmelnytsky: Podillya. (in Ukrainian)

11 Artemenko V. (2003) Osnovy vymirjuvannja reghionaljnogho rozvytku z vykorystannjam koncepciji jakosti zhyttja [Fundamentals of measuring the regional development using the concept of quality of life]. Region, economy, vol. 2. pp. 134. 
of the population (the elderly, the poor, the disabled and the sick etc.) $)^{12}$.

The welfare policy should be based on an assessment of the current problems of the socio-economic status of the Ukrainian population. The data of the State Committee of Statistics in Ukraine and Social Surveys give grounds to highlight the following trends in recent years:

- the propertyaspect, the socio-economic stratification of the population, the reduction of the share forthe labor income in the welfare structure;

- the low level of the purchasing power of the population, the presence of the layer of the people earning income on the margin of poverty, including some employees of the budget sector;

- the high level of the "psychological poverty" when 70-80\% of people consider themselves poor;

- the existence of the "grey market" and the illegal or semiillegal employment without social guarantees, difficulties in the employment and realization of the potential, including intellectual, especially for young people;

- the labour migration, the outflow of the labour, mainly of the reproductive age;

- the low employment rate of disabled people, most of whom are of working age;

- the coverage of various social benefits and social assistance up to $70 \%$ of the population, the inclination of the part of the population to the social maintenance and at the same time the insufficient development of the network of the modern social institutions intended for the representatives of socially vulnerable population groups;

12 Fertikova T.M. (2007) Dobrobut jak ob’jekt derzhavnoji socialjnoekonomichnoji polityky $\mathrm{v}$ Ukrajini [Well-being as an object of the state socioeconomic policy in Ukraine]. Nauk. pr. Chornomor. derzh. un-tu im. P. Moghyly. Ser. «Ekonomika» [Science. Petro Mohyla Black Sea National University. "Economy"] (electronic journal), vol. 51, no. 64. Retrieved from: www.nbuv.gov.ua/ Portal/Soc_Gum/Npchdu/Economy/2007_51/5 1-4.pdf. (accessed 10 January 2019). 
- the "greying" of the nation which causes the significant economic and demographic burden on the able-bodied citizens;

- the spread of the socially dangerous diseases (tuberculosis, HIV/ AIDS, and other sexually transmitted diseases, drug addiction etc.), which is an indicator of a nation's social "ill health";

- the lack of the resources, both public and private, to improve and maintain a healthy lifestyle;

- the commercialization of the health care system, the unavailability of the medical services and medicines due to their high cost to a large proportion of the population;

- the decrease in the quality of the secondary, special and higher education, inaccessibility of quality higher educationfor many families;

- the limited ability of the large part of the population to satisfy cultural needs.

Taking into account the current ideas about the directions of the population welfare growth and the current situation in Ukraine gives grounds to determine the tasks of the public administration in the field of the social development. The management objects should be:

1) the level of incomes (the expenditures and savings of the population), in particular, the level of the employment, wages, property income, social transfers and the provision of social services;

2) the availability of the benefits important for the preservation and accumulation of the human capital, namely:

- health and education which affects employment and income;

- public goods;

- the benefits that are not vital, but the opportunity to receive them is an incentive for the active economic behaviour.

This means that the essence of the state influence in the transition economy and the formation of the social state should stimulate market mechanisms and implement the principles of a socially oriented market economy as well, and to implement the effective social policy.

The public administration of the social development is the mechanism for achieving the goals of the economic and social policy 
based on the legislative imperatives that determine the real standard of living, well-being, employment, social support. At the same time, by the definition of V. Skurativsky and A. Skurativsky, the social policy must be based on the three basic principles:

1) the priority of the problems in the social protection of the population;

2) increasing the role of the personal labour income in meeting the socio-cultural and household needs of the population and eliminating dependency on this basis;

3 ) the organization of a new mechanism for financing the social sphere, that is the transition from the state paternalism to the social partnership.

The social protection of the population in the conditions of the transition to the market requires the differentiation of the social support according to the level of incomes, the degree of the working capacity, and in some cases based on the principle of the employment in the social production. Some sections of the population need special social programmes, which is caused by the presence of a high degree of the social inequality in the Ukrainian society. The implementation of such management approaches will help to achieve approximation to the European quantitative standards of the social development, which, in particular, is provided by the Law of Ukraine (as amended) "On the State Social Standards and State Social Guarantees" dated 5 October 2000.

The conditions of the public administration inthe social security of the population are determined by the specific social welfare of the population as a management object. First of all, we are talking about multi-entity, multi-level, weak structured social sphere, which has the capacity for the self-organization. Moreover, it should be borne in mind that the social reproduction is a complex, multiple, ambiguous process that is influenced by the global trends and international commitments of the country, the state of the legal culture and social values.

The social sphere and social relations are closely linked to economic issues. After all, the economic decisions of the state related 
to, for example, the macroeconomic stability and the reduction of the budget expenditures, which are simulteniously social in their consequences, since their implementation will affect the income of the population and the level of its social protection. At the same time, it is important to note that the initial socio-economic status is not considered by many scholars to be the determining factor for the development of the social well-being. It is true that the economies of Germany and Japan were completely destroyed at the end of World War II, but the rapid socio-economic growth soon began. At the time of the collapse of the Soviet Union, Ukraine and other post-Soviet countries had a full-fledged economy and the ample opportunities for the development but for almost 20 years of the independence there had been a social and economic setback. This leads to the conclusion that for the social development of the state is not so much economic power as the organizational principles of the embodied form of the state (including those embodied in the relationship "power - society") 13 . That is, the degree of the authorities responsibility to the society also determines the state of the population well-being as a management object.

In modern Ukraine, financing of the socio-economic programmes is carried out not only at the expense of the state funds, but also at the expense of the local budgets, the funds of the enterprises, organizations, and the population. Charitable social assistance funds can play a certain role in improving the well-being of the population. Therefore, a purposeful mechanism for managing the public welfare is implemented through specific public institutions, namely the entities that collectively form the governing system, which includes the state (in particular, the President of Ukraine, the Verkhovna Rada of Ukraine, the Cabinet of Ministers of Ukraine, the

13 Kovalska N. (2014) Teoretyko-metodologhichni zasady mekhanizmiv derzhavnogho upravlinnja systemoju profesijnoji pidghotovky v Ukrajini [Theoretical and methodological foundations of the mechanisms of the state management for the training system in Ukraine]. Aktualjni problemy derzhavnogho upravlinnja [Actual problems of public administration] (electronic journal), no. 2 (54), pp. 8. Retrieved from: http://nbuv.gov.ua/UJRN/apdyo_2013_2_4. (accessed 10 January 2019). 
relevant central bodies of the state power), political parties, nongovernmental organizations and others.

At the regional and local levels of management, these functions are performed by the relevant authorities and institutions. The highest level of the competence, professionalism of the civil servants and employees of the relevant institutions, the respectful attitude to solving problems for the people becomes the main indicator of the public welfare in the daily life of the population, the indicator of the effectiveness of the economic and social policy of the state at the regional and local levels. At the present stage, there is a duplication of the functions for the authorities in ensuring the welfare of the population, the lack of the coordination and interaction in the management structures at different levels. Another problem is that in Ukraine the functions of the regional local authorities are wider than in many other countries of the world, with the minimal financial resources for their realization. The way out of this situation should be the social obligations of the state, which can be defined as a legally fixed set of social benefits, i.e. services, benefits, subsidies etc. The state is obliged to make them available to those citizens who need them at the expense of the budgetary resources.

The identified problems raise the issue of the specialization for the levels of public administration to ensure the welfare of the population. In the presence of the general objectives of the social development, such specialization can ensure the formation of the integrated system of the socio-economic policy, which is based on all branches of the state power, local self-government and especially the activity of citizens. Within the integrated system of the responsibility for the realization of the social goals and objectives, it is necessary to distinguish the following key levels: central, regional, local selfgovernment bodies, production structures, citizens. At the central level, the following issues need to be addressed:

- the development of the legal framework regulating the division of the competences in the sphere of ensuring the well-being of the population between the central, regional and local self-government bodies; 
- the development of the clear mechanisms for the implementation of the laws, the priority financial support of the state social programmes;

- the regulation of the minimum wage and pension;

- streamlining benefits and social guarantees;

- the creation of the favourable tax conditions for the development of the charitable assistance, the regulation of citizens' access to medical, educational, social, socio-cultural services, the regulation of the issues related to the labour migration and the development of the social and labour relations;

- the creation of the effective system of the civil rights protection and security.

At the regional level, the main promising areas for improving the social welfare of the population should be:

- the elaboration and implementation of the programmes for the economic development of the region;

- the effective measures in the labour market to optimize the employment structure and reduce the unemployment;

- the elaboration and implementation of the priority programmesrelating to the social support for the families, children, women, people with disabilities, other vulnerable groups of the population;

- the creation of the single regional information space, monitoring of the indicators for the social sphere of the region;

- the separation of the powers to ensure the social welfare for the population at the regional level and at the level of local selfgovernment bodies;

- ensuring the stable funding for the targeted social assistance;

- providing the continuous improvement of the quality for the social, medical, educational and other services (in the context of the modern technologies of the XXI century).

The public administration of the social development must be based on both general and specific governance mechanisms. The task of the social development management is to specify the general objectives of the higher state level, taking into account the formed 
system of the public administration, local self-government, as well as the socio-economic conditions and constraints existing in the state and relevant to the social sphere. The management objects should include both the level of incomes and the availability of the benefits essential for the preservation and accumulation of the human capital, comprising the educational, medical and social services.

Today the investment mechanism of the Ukrainian social development is an open system with the vague boundaries, which is caused by the multi-entity, multi-level, the weak structured social sphere and ambiguous understanding of the social development as an object of governance. Increasing the development of the social potential is possible only under the condition of the differentiation of the management activity in accordance with the objects of the influence and the problems, without which it is impossible to define the boundaries for the management.

Thus, let us consider in more detail the organizational structure of the investment mechanism of the public policy in the public development. In theresearches, the description of the organizational structure forthe public policy mechanism often begins with the identification of its elements. O. Fedorchak points out the following main elements: methods, levers, tools, policy, legal, regulatory and information support. At the same time she notes that the composition of the public administration mechanism in the certain sphere of the social development will change, depending on the features of the particular sphere ${ }^{14}$.

In the mechanisms of the public policy L. Prykhodchenko identifies the target, regulatory, organizational, economic and information components. She claims that the target component is a primary element of the mechanism's structure. The legal part of the

14 Fedorchak O.V. (2008) Klasyfikacija mekhanizmiv derzhavnogho upravlinnja [Classification of the mechanisms of the public administration]. Demokratychne vrjaduvannja [Democratic governance] (electronic journal), vol. 1, Retrieved from: http://www.nbuv.gov.ua/e-joumals/DeVr/2008-01/O_Fedorchak.pdf. (accessed 10 January 2019). 
second component defines all the possible sets of the modes for functioning, whereas the normative part of the second component is formed through the orders and decisions of the local authorities. In this case, the change of the legal acts is much slower than that of the normative ones, which makes the latter more important for the functioning of the public administration mechanism. The functionality of the organizational component involves defining the rights, responsibilities, competencies, and responsibilities inthe decisionmaking process. The relationship between the organizational and regulatory components shows that the legal documents regarding the allocation of the competences set boundaries but do not define the internal content. The latter happens in the process of functioning of the organizational component. The essence of the economic component is to evaluate the results of the management process. Accordingly its purpose is to assess the effectiveness of the management decisions. An indispensable component of any mechanism of the public administration is the informational part, which actually has a crosscutting effect. The content characteristic of this component contains the structure of the information database, the sources and consumers of the information, the technological process of its processing ${ }^{15}$.

V. Bodelan views the organizational structure of the public administration mechanism as a set of management units and organizational links between them for the realization of the goals and objectives of the state as a whole or in a separate direction. In his opinion, it characterizes the relationships of the set of the units and the existing organizational links between them, which express the interaction and coordination of the elements within the system. Its interaction and coordination are based on the goals and objectives that are realized through the functions. Moreover, the functions are

${ }^{15}$ L. Prykhodchenko (2009) Struktura mekhanizmu derzhavnogho upravlinnja: vzajemozv'jazok komponentiv ta faktory vplyvu na efektyvnistj [The structure of the mechanism of the administration: the interconnection of the components and factors of the influence on efficiency]. Bulletin of the National Academy of Public Administration under the President of Ukraine, vol. 2, pp. 108-110. 
essential for the organizational structure, they determine the need for the certain elements of the system and the architecture of this system. Therefore, the organic interconnection of the organizational structure and the functional structure in practice leads to the fact that they appear as a whole, as an organizational and functional structure, built on the principle of the division of the functions vertically and horizontally for the structure. He points out that the practice convincingly shows that the formation of the organizational and functional structure should be carried out according to H. Chandler's well-known principle "a strategy defines a structure" in this way:

- establishing of the goals and sub-goals;

- defining of the functions and sub-functions necessary for the realization of the goals and sub-goals;

- creating of the appropriate structures (entities) to perform the certain functions ${ }^{16}$.

$\mathrm{Yu}$. Kunayev, studying the issues for the management in the customs service, considers the structure of the public administration mechanism as a set of 6 components:

- the target part as a set of all the goals for the management activities;

- the functional part that includes the types of the management activities (cognitive-programmatic and organizationally regulatory) necessary to perform the basic functions of the organization;

- the methodological part involves those methods that are used in the performance of all the types of the management activities, i.e. they ensure the implementation of the functional part;

- the part that reflects the set of the principles, norms or rules according to which it is necessary to perform successful management activities;

16 Bodelan V.R. (2013) Orghanizacijno-funkcionaljni struktury: osoblyvosti vplyvu chynnykiv jikh pobudovy na efektyvnistj funkcionuvannja orghanizacijnogho mekhanizmu derzhavnogho upravlinnja [Organizational and functional structures: features of the influence of the factors relating to their construction on the efficiency of functioning of the organizational mechanism of the public administration]. Public administration: theory and practice, vol. 3. pp. 55. 
- the instrumental part comprises the management decisions, powers, means of the information, material and energy influence on the management object;

- the technological part implies the technology of the preparation, adoption and execution of the management decisions.

Considering the above views of the various researchers on the structure of the public administrationmechanism, we can draw the following conclusions:

- the main emphasis is made on the constituents of the mechanism, and their description has a rather general direction;

- less attention is paid to the interconnections between the components of the mechanism;

- the goals and the subjects of the mechanism are not always distinguished as separate constituents;

- there is no clear relationship between the definition of the public administration mechanism and its structure;

- the functions determine the organizational structure of the public administration mechanism and cause the necessity for certain entities;

- the organic interconnection of the organizational and functional structure of the mechanism in practice leads to the understanding as a whole, as its organizational and functional structure.

However, the current state of the domestic economy requires the implementation of the structural transformations of the investment mechanism concerning the public policy in the social development aimed at forming a competitive environment founded on the innovative basis of such mechanism. In the current context, the elaboration and implementation of the mechanisms for the active public policy in the investment sphere, as well as a flexible system of the interaction between the market structures and state regulation, become particularly relevant. 


\section{The investment mechanism of the public policy in the social development}

The practical achievement of the objectives for the investment policy is connected with the creation and ensuring the effective functioning of the mechanism for its implementation. However, it should be noted that the authors of a number of scientific works, when considering the issues onthe investment management, usually focus on the methods with the help of which it is possible to influence this type of the activity, avoiding the content and structure of such a category as the "mechanism of the investment policy implementation".

The distinguished characteristics inherent in this category of "mechanism", combined with the attractiveness of a particular region, allow to open and supplement the meaning of this concept in relation to the investment process. We emphasize that the mechanism (including the investment mechanism) is the result of the purposeful activity and represents a set of the institutions, norms, rules that provide under certain conditions the formation of the given phenomena.

According to the adopted general scheme for building a regulatory mechanism, the model representation of the mechanism under study includes the following elements:

- the subject is the driving force that meaningfullystarts this mechanism;

- the objects include the economic entities, the economic environment;

- the purpose presupposes programmable desired results of the mechanism action;

- the methods involve the tools, modes and technologies of the processes forthe achievement of the set goals;

- the form reflects the organizational and legal registration of the methodological support;

- the means comprise a set of the types and sources of the resources used to achieve the set goals.

There are different points of view regarding the structure of the mechanism for the regional policy implementation, however, there are 
no fundamental differences between them. Thus, the investment mechanism of the public policy in the social development involves public institutions that implement specific measures within the set goal, as well as the resources allocated to achieve the goals and methodological approaches to the formation and implementation of the investment policies that ensure the conduct of the independent policy at the state and regional level.

The investment policy is a system of measures taken by the authorities and management to attract and use the investment resources of all the forms of ownership for the purpose of sustainable and socially oriented development.

The investment policy formation and implementation system should be constructed from three interconnected and interdependent blocks.

The first block incorporates the main factors whichsignificantlyaffect the content of the investment policy and, accordingly, the mechanism of its implementation. They are as follows:

1) the investment climate;

2) the indicators of the investment potentialformation;

3) the level of the investment risks;

4) the factors regarding the internal and external influence.

The first block is mainly related to the objectively determined regional peculiarities of the economy, which in turn determines the complex of the natural geographical, historical, demographic and other factors. The factors of the external influence are connectedwith the influence of the conditions of the activity defined by the national legislation and the national economic and investment policy.

The second block presents the stages of the investment policy formation:

1) defining the goals and main priorities of the investment policy;

2) the formation of the investment programme;

3) the elaboration of the principles for the mechanism of the investment policyimplementation. 
The goals and priorities of the investment policy depend on the goals and objectives of the general socio-economic policy.

The third block of the investment policy implementation mechanism should consist of the means used to achieve the objectives of the policy. The basic tasks of this block comprisethe complex of the applied management methods (economic, administrative, social and psychological) and the system of ensuring its operation (legal, organizational and informational).

The implementation of the investment policy mechanism should become more targeted in terms of the impact of the management structures on all the participants of the investment process in the interests of achieving the set goals of the socio-economic development in the conditions of the insufficient resources.

The formation and implementation of the investment policy is a complex multi-stage system of tasks, where at each stage there are separate elaborations and constant adaptation to the conditions of functioning of the socio-economic system.

The investment mechanism of the public policy for social development should be understood as a system of legal, organizational and economic measures that contribute to the formation of the competitive production and increase of its efficiency. The dynamism of the investment process leads to the presence of the flexible forms of its organization and management, which, in turn, requires the complex regulation of its main stages with a focus on the final results. In the course of the investment activity, all its participants use a combination of different methods with the appropriate variety of forms, incentives and restrictions. All this, of course, reflects the complexity of both the investment process and the mechanism of the public policy implementation for the social development, the essence of which is the purposeful influence of the authorities and management on the development of the investment process in the direction set by the strategic documents of the socio-economic development. Based on this understanding of the essence of the mechanism under consideration, it can thus be emphasized that the investment policy 
is the part of the regional socio-economic policy, so that its implementation should be aimed at achieving the goals of the socio-economic development.

Under the investment mechanism for the public policy implementation in the social development it is necessary to understand the set of methods that ensure the operation of the systems by which the public authorities influence the participants of the investment process in order to solve the primary tasks of the socio-economic development.

The main goals of the mechanism functioning are:

- the mobilization of the investment resources;

- the formation of the investment flows and directing them to the sectors and branches of the economy, where the highest efficiency from investments is provided;

- increasing the efficiency of the investment use;

- the increase of the investment activity.

The content of the investment mechanism of the public policy for the social development can be characterized as a process of the concentration and mobilization of the investment resources, the organization of the control over their effective use, the development of the regulatory influences aimed at strengthening the positive tendencies of the economy as a whole.

This understanding of the content of the proposed mechanism makes it possible to distinguish its main structural components in the form of the separate blocks, each of which has its own content and meaning, which is realized in different forms and by different methods.

The functions that the mechanism is intended to perform are:

- streamlining the reproduction process through the creation of the favourable investment environment and the appropriate system of the state regulation;

- the realization of the investment potential for the territory;

- the formation of the motivational mechanism of the investment process; 
- the reduction of the possible or expected contradictions of the economic interests relating to the investment entities.

\section{CONCLUSIONS}

Thus, the peculiarity of the investment mechanism of the public policy implementation in the current conditions of the destabilization of the economic relations is its focus on reconciling the interests of all the components of the mechanism. That is whythe important part in the structure of the mechanism under consideration is the motivational block, which ensures the interaction of the participants in the investment process not only among them but also with the external environment.

\section{SUMMARY}

The article summarizes the approaches to understanding the mechanisms of the public administration, deals with the content and structure of the investment mechanism of the public policy for thesocial development in view of the modern interpretations relating to the social development, the responsibility of the different levels of the public administration for enhancing the development of the social potential. The issue of the mechanisms is one of the central problems related to the state regulation of any public process.

\section{REFERENCES}

1. DiNitto D. M. (2003) Social Welfare: Politics and Public Policy. Boston: Pearson Education. 450 p.

2. Yuzkov L.P (1993) Ghosudarstvennoe upravlenye $v$ polytycheskoj systeme razvytogho socyalyzma [Public administration in the political system of the advanced socialism]. Kyiv. (in Ukrainian)

3. Bryukhovetska N.Yu. (1999) Ekonomichnyj mekhanizm pidpryjemstva $v$ rynkovij ekonomici: metodologhija $i$ praktyka [The economic mechanism of an enterprise in the market economy: methodology and practice]. Donetsk: IEP NAN of Ukraine. (in Ukrainian) 
4. Korotych O.B. (2006) Derzhavne upravlinnja reghionaljnym rozvytkom Ukrajiny [The public administration of the regional development of Ukraine]. Kharkiv. (in Ukrainian)

5. Astapova H.V. Astapova Ey.A., Loiko D.P. (2001) Orghanyzacyonno-ekonomycheskyj mekhanyzm korporatyvnogho upravlenyja $v$ sovremennykh uslovyjakh reformyrovanyja ekonomyky Ukrayny [The Organizational and economic mechanism of the corporate governance in the current conditions of reforming the Ukrainian economy]. Donetsk. (in Ukrainian)

6. Kovaluk O.M. (2002) Finansovyj mekhanizm orghanizaciji ekonomiky Ukrajiny (problemy teoriji $i$ praktyky) [The financial mechanism of the organization of the Ukrainian Economy (The problems of the theory and practice)]. Lviv. (in Ukrainian)

7. Yeremenko-Hryhorenko O.A. (1999) Orghanyzacyonnoekonomycheskyj mekhanyzm upravlenyja khozjajstvennoj dejateljnostjju predpryjatyja [The organizational and economic mechanism of the management inthe economic activity of the enterprise]. Donetsk. (in Ukrainian)

8. Amosov A.Yu. (2001) Peretvorennja mekhanizmiv derzhavnogho reghuljuvannja ekonomichnogho rozvytku [The transformation of the mechanisms of the state regulation for the economic development]. The public administration and local selfgovernment, vol. 2, pp. 10-16.

9. Obolensky O. (1998) Derzhavna sluzhba Ukrajiny: realizacija systemnykh poghljadiv shhodo orghanizaciji ta funkcionuvannja [State Service of Ukraine: Implementation of Systematic Views on Organization and Functioning]. Khmelnytsky: Podillya. (in Ukrainian)

10. Artemenko V. (2003) Osnovy vymirjuvannja reghionaljnogho rozvytku z vykorystannjam koncepciji jakosti zhyttja [Fundamentals of measuring the regional development using the concept of quality of life]. Region, economy, vol. 2. pp. 134.

11. Fertikova T.M. (2007) Dobrobut jak ob'jekt derzhavnoji socialjno-ekonomichnoji polityky v Ukrajini [Well-being as an object of the state socio-economic policy in Ukraine]. Nauk. pr. Chornomor. 
derzh. un-tu im. P. Moghyly. Ser. "Ekonomika" [Science. Petro Mohyla Black Sea National University. "Economy"] (electronic journal), vol. 51, no. 64. Retrieved from: www.nbuv.gov.ua/ Portal/Soc_Gum/Npchdu/Economy/2007_51/5 1-4.pdf. (accessed 10 January 2019).

12. Kovalska N. (2014) Teoretyko-metodologhichni zasady mekhanizmiv derzhavnogho upravlinnja systemoju profesijnoji pidghotovky v Ukrajini [Theoretical and methodological foundations of the mechanisms of the state management for the training system in Ukraine]. Aktualjni problemy derzhavnogho upravlinnja [Actual problems of public administration] (electronic journal), no. 2 (54), pp. 8. Retrieved from: http://nbuv.gov.ua/UJRN/apdyo_2013_2_4. (accessed 10 January 2019).

13. Fedorchak O.V. (2008) Klasyfikacija mekhanizmiv derzhavnogho upravlinnja [Classification of the mechanisms of the public administration]. Demokratychne vrjaduvannja [Democratic governance] (electronic journal), vol. 1, Retrieved from: http://www.nbuv.gov.ua/e-joumals/DeVr/2008-01/O_Fedorchak.pdf. (accessed 10 January 2019).

14. Prykhodchenko L. (2009) Struktura mekhanizmu derzhavnogho upravlinnja: vzajemozv'jazok komponentiv ta faktory vplyvu na efektyvnistj [The structure of the mechanism of the administration: the interconnection of the components and factors of the influence on efficiency]. Bulletin of the National Academy of Public Administration under the President of Ukraine, vol. 2, pp. 108-110.

15. Myrna N.V. (2010) Opracjuvannja kompleksnogho mekhanizmu derzhavnoji reghionaljnoji polityky [Elaboration of a complex mechanism of the state regional policy]. Derzhavne budivnyctvo [State building] (electronic journal), v0l. 1. Retrieved from: http://nbuv.gov.ua/j-pdf/DeBu_2010_1_20.pdf. （accessed 10 January 2019).

16. Bodelan V.R. (2013) Orghanizacijno-funkcionaljni struktury: osoblyvosti vplyvu chynnykiv jikh pobudovy na efektyvnistj funkcionuvannja orghanizacijnogho mekhanizmu derzhavnogho 
upravlinnja [Organizational and functional structures: features of the influence of the factors relating to their construction on the efficiency of functioning of the organizational mechanism of the public administration]. Public administration: theory and practice, vol. 3. pp. 55.

Information about the author: Oksana Marukhlenko, $\mathrm{PhD}$ in Economics, Doctoral Student at the Department of Social and Humanitarian Policy, National Academy of Public Administration under the President of Ukraine 20, Ezhena Potie str., Kyiv, 02000, Ukraine ORCID ID: orcid.org/0000-0001-8050-6615 


\section{THE TAXATION SYSTEM OF UKRAINE: STATE OF AFFAIRS AND PROSPECTS OF REFORMING}

\section{Dmytro Mishchenko}

\section{INTRODUCTION}

The result of reforms, introduced in Ukraine during the independence period became fundamental socioeconomic transformations. Along with that the inconsistency of reforming processes, the absence of entire concept of national economic policy, substantial structural disparities in the economy led to the deep and sustained socioeconomic crisis of society. One of the main reasons for the intensification of the crisis phenomena in Ukraine was the undeliberate tax policy of the state, which resulted in the restraint of innovation and investment processes, which then leads to the insufficient payment by budgets of tax revenues of all levels. Considering the constant deficit of the state budget of Ukraine, the lack of financial resources to fulfill the socioeconomic functions of the state, the emergence of additional financial needs due to aggravation of geopolitical, social and financial crises, improvement of tax policy in Ukraine is an important factor in improving the competitiveness of the national economy. Despite certain progress in the reform of Ukraine's tax system in recent years, it still does not provide adequate encouragement for investment inflows and innovative economic development.

Writings of many Ukrainian researches are dedicated to the issues under investigation, among them: O.Ya. Bozulenko, T.A. Vasilyeva, O.M. Desyatnyuk, Y.B. Ivanov, V.M. Kmit, A.I. Krisovatyi, S.V. Leonov, T.V. Merkulova, N.S. Pedchenko, I.V. Ped, K.P. Proskura, O.V. Revenko, D.M. Serebryanskyi, O.O. Suntsova, S.V. Sluhai, T.V. Tuchak, I.O. Cymbalyuk, T.V. Chumakova, K.I. Shvabiy, I.M. Shkola and others. Despite the increased academic interest to the problem of tax system development 
and the considerable amount of scientific research results in this field, there is still no integrated approach to its solution.

To achieve a successful economic advancement is possible upon condition of a strong, sound financial capability, the basis of which is budget incomes as well as tax revenues. A legal framework, regulating tax collection and administrative bodies, controlling the implementation of legislation by economic entities have been developed in Ukraine, but it is impossible to say that the tax system is efficient and reaches its functional purpose.

The tax and budget systems have always been and will be subjected to criticism, as they must be based on mechanisms for overcoming many social and personal contradictions. It is almost impossible to achieve optimality in their resolving. Especially since the economy is at different stages of development (ramp-up, peak, contraction, crisis) in each period, depending on which the contents of both tax and budgetary policies differ, exacerbating the mentioned contradictions and increasing the social tensions regarding the assessment of fairness and efficiency of the system (first of all, in relation to the taxation: between the state, on the one hand, and business entities and the population as taxpayers, on the other).

In fact, such a state of affairs often leads to violation of certain, even universally recognized, principles of fiscal policy, such as fairness, efficiency, stability.

\section{Analysis of the state of affairs of Ukrainian taxation system}

One of the major purposes of the national financial policy is the implementation of effective taxation system.

The taxation system is a set of taxes established in the country that are interconnected, complement each other and do not contradict the system as a whole and its other elements ${ }^{1}$.

V. Vyshnevskyi characterizes the taxation system not only as a set of tax laws but also as an institution that includes a specific social

1 Курносова К.В. Напрями реформування доходної бази місцевого самоврядування. Наукові праці НДФІ. 2007. 3(40). С. 25-33. 
layer of financial specialists, rules and traditions of accounting, established by the state fiscal and financial institutions, formal and informal procedures related to the calculation, payment and distribution of statutory payments ${ }^{2}$.

One of the significant factors in ensuring the growth of the country's economy is an effective taxation system and a tax mechanism that is functioning and regulated by the tax legislation.

The role of the tax mechanism resides in the fact that it allows rationalizing tax relations, basing on tax law and the tax assessment governance.

From the perspective of functional content, the essence of the tax mechanism can be formulated as follows: it is a set of financial and budget spheres of activity, which interact with each other and are regulated by specific legislative and legal norms of the state, and determine the establishment, assessment of planned, actual and forecast tax liabilities of the subjects of tax legal relations, implementation of scientifically substantiated actions on the current interference in the process of budget performance of the country, both stimulating (tax regulation) and sanction measures of influence in violation of tax legislation (tax control).

The tax mechanism can be considered as a certain way of functioning of its elements in the tax management system, through which the economic interests of the subjects of tax relations are realized. Among the features which are peculiar to tax mechanism of our state, scientists separate the following: fiscal and redistributive; control function; planning function; regulation function; supervising function; coercive function; information function; advisory function.

The components of the tax mechanism at the macro and microeconomic levels have some differences, as follows:

2 Вишневський В., Вєткін А. Відхід від сплати податків: теорія і практика. Донецьк: Монографія IНАН України, Інститут економіки промисловості, 2003. 62 с. 
- The subject of implementation of the tax mechanism at the macroeconomic level is the state, and at the microeconomic level is the economic entity.

- The object of control at the macroeconomic level is budget system tax revenues, and at the microeconomic level is a complex of tax liabilities and taxpayers' tax payments. Although these objects are closely related, there is also an indirect interinfluence.

Having regard to the above said, it is necessary to pay attention to one of the main components of the functioning of the tax system, to the concept of "taxes".

With the help of taxes, the gross domestic product is redistributed and the business activity of members of society is affected, market self-regulation is changing, the state policy of economic development is implemented. Taxes are an objective social phenomenon, so when constructing a tax system, it is necessary to proceed from the realities of the socioeconomic state of the country, and not be guided by desiderates, even if the best, but unenforceable ones.

The tax is a complex economic category that characterizes the economic relations between the state and members of society that arise in the process of distributing GDP for the removal of a part of gross national income and redistribution by the state with the aim of financing government expenditures ${ }^{3}$.

According to the Tax Code of Ukraine, tax is a mandatory, unconditional payment to the appropriate budget, which is paid by taxpayers ${ }^{4}$.

Therefore, the tax has legal, economic and social characteristics. The legal content of taxes is manifested through a system of legal rules. Taxes are established exclusively by the state in accordance with the law by legally enforceable rules. In the implementation of the

${ }^{3}$ Малишкін О. I. Коефіцієнт податкового навантаження на мікрорівні: розрахунок та застосування Бухгалтерський облік і аудит. 2015. № 1. С. 18-25.

${ }^{4}$ Податковий кодекс України: Закон України від 02.12.2010 № 2755-VI URL: https://zakon.rada.gov.ua/laws/show/2755-17 
essence of tax as a legal category, the basis is the change of ownership that means the transfer of property to the state and its appliance in order to meet social needs.

In economic terms, taxes are an instrument of state distribution and redistribution of income and financial resources.

The social content of taxes gives the state the opportunity to influence the sphere of economic relations in society.

The tax system forms the basis of the functioning of any modern state. It is a collection of taxes, fees, and other required payments, contributions to the budget and government trust funds that operate in due process of law.

In a more comprehensive sense, the tax system is governed by the rules of financial law, enshrined in laws and regulations concerning tax liabilities, a set of tax relations mediated by financial institutions that provide tax administration and manifest in specific forms of taxation ${ }^{5}$.

The state through the budget ensures the raising of funds needed to ensure the socioeconomic development of the country and use them for the purpose of fulfilling its functions, which are entrusted on the budget institutions and spending units. At that, the essential part of gross domestic product accumulates within the consolidated budget and is used to ensure the economic development of the country, to solve social problems, to pay state administration bodies, and to ensure defense capacity.

The economic conditions of the country, and accordingly the level and dynamics of tax revenues need continuous monitoring and research in order to prevent adverse effects on the country's development. Let's further analyse the structure of actual tax revenues for general and special funds of the Consolidated Budget of Ukraine.

5 Макогон В.Д. Формування доходів місцевих бюджетів у зарубіжних країнах. Наукові пращчі НДФІ. 2008. № 1 (42) С. 56-66. 
Table 1

Composition and dynamics of tax revenues of the Consolidated Budget of Ukraine, UAH billion ${ }^{6}$

\begin{tabular}{|l|c|c|c|c|}
\hline & $\mathbf{2 0 1 6}$ & $\mathbf{2 0 1 7}$ & $\mathbf{2 0 1 8}$ & $\begin{array}{c}\text { Absolute } \\
\text { variation 2018 } \\
\text { from 2016 (+,-) }\end{array}$ \\
\hline General fund & 645,13 & 791,36 & 943,678 & 298,548 \\
\hline Special fund & 5,65 & 36,79 & 42,68 & 37,03 \\
\hline Total & 650,78 & 828,15 & 986,358 & 335,578 \\
\hline
\end{tabular}

In 2018, tax revenues of the general fund of the Consolidated Budget of Ukraine increased by UAH 298.55 billion compared to 2016. Tax revenues of the special fund of the Consolidated Budget of Ukraine increased by UAH 37.03 billion. In total, the tax revenues of the Consolidated Budget of Ukraine increased by UAH 335.57 billion.

In the modern world, the basis of fiscal policy is the tax policy of the state, which effectiveness depends on the socioeconomic development of the country. The Ukrainian realities in this respect show that in recent years the central focus of tax policy has been on taxation of consumption taxes, which provide about $55 \%$ of the Consolidated budget tax revenues.

Table 2

Structure of tax revenues of the Consolidated Budget of Ukraine, UAH billion

\begin{tabular}{|l|c|c|c|c|}
\hline & $\mathbf{2 0 1 6}$ & $\mathbf{2 0 1 7}$ & $\mathbf{2 0 1 8}$ & $\begin{array}{c}\text { Absolute } \\
\text { variation 2018 } \\
\text { from 2016 (+,-) }\end{array}$ \\
\hline General fund & 99,13 & 95,56 & 95,67 & $-3,46$ \\
\hline Special fund & 0,87 & 4,44 & 4,33 & 3,46 \\
\hline Total & 100 & 100 & 100 & \\
\hline
\end{tabular}

6 Виконання Державного бюджету / сайт Державної казначейської служби України URL: http://www.treasury.gov.ua/maitalog/list?Currdir=311513 
In 2018, the interest of tax revenues of the general fund of the Consolidated Budget of Ukraine decreased by 3.46 percentage points compared to 2016. Accordingly, the tax revenues of the special fund of the Consolidated Budget of Ukraine have increased.

Tax revenues take the lead among the various methods of mobilization of budgetary resources and instruments of state regulation of the economy. They are the most adequate and objective reflection of the state of the national economy. The use of taxes as financial leverages is based on the introduction of various instruments for regulating economic proportions, providing the necessary level of social safety nets and so on. For any country that has market-based economy, taxes are a kind of leverage to regulate and prevent negative economic trends. Taxes are a particular mechanism that provides a link between national interests and the interests of individual entities.

It is taxes that determine the nature of the relationship between enterprises of all forms of ownership with the state and local budgets, with banking institutions, state executive bodies, etc ${ }^{7}$.

Table 3

Composition of tax revenues of the general fund of the Consolidated Budget of Ukraine, billion UAH

\begin{tabular}{|l|c|c|c|c|}
\hline \multicolumn{1}{|c|}{$\mathbf{1}$} & $\mathbf{2 0 1 6}$ & $\mathbf{2 0 1 7}$ & $\mathbf{2 0 1 8}$ & Variation, \% \\
\hline Tax revenues & $\mathbf{2}$ & $\mathbf{3}$ & $\mathbf{4}$ & $\mathbf{5}$ \\
\hline $\begin{array}{l}\text { Income taxes, profits } \\
\text { taxes, market gains taxes }\end{array}$ & 645,13 & 791,36 & 943,67 & 146,28 \\
\hline Property taxes & 0,00 & 256,09 & 334,95 & 168,31 \\
\hline $\begin{array}{l}\text { Rental taxes and } \\
\text { payments for the use } \\
\text { of other environmental } \\
\text { resources }\end{array}$ & 46,61 & 51,13 & 49,91 & 107,08 \\
\hline
\end{tabular}

7 Жиляєва Н. Фіскальна політика держави в період світової економічної кризи та напрями підвищення її ефективності. Вісник Київського національного університету ім. Тараса Шевченко. 2010. № 119. С. 49-51. 
End of table 3

\begin{tabular}{|l|c|c|c|c|}
\hline \multicolumn{1}{|c|}{$\mathbf{1}$} & $\mathbf{2}$ & $\mathbf{3}$ & $\mathbf{4}$ & $\mathbf{5}$ \\
\hline $\begin{array}{l}\text { Domestic taxes on } \\
\text { goods and services }\end{array}$ & 337,26 & 422,16 & 474,92 & 140,82 \\
\hline $\begin{array}{l}\text { Taxes on international } \\
\text { trade and external } \\
\text { transactions }\end{array}$ & 20,37 & 22,90 & 23,82 & 116,94 \\
\hline $\begin{array}{l}\text { Fees for fuel and } \\
\text { energy resources }\end{array}$ & 0,28 & $-0,01$ & $-0,01$ & $-2,14$ \\
\hline Local taxes & 42,26 & 52,59 & 61,03 & 144,42 \\
\hline Other taxes and charges & $-0,66$ & $-13,50$ & $-0,95$ & 143,94 \\
\hline
\end{tabular}

The general fund of the Consolidated Budget of Ukraine in 2018, funded with the money coming from the tax revenues, got by $46.28 \%$ more than in 2016.

Tax revenues, income taxes, market gains taxes, local taxes, domestic taxes on goods and services, as well as taxes on international trade and external transactions were characterized by substantial growth of the tax revenues of the general fund of the Consolidated Budget of Ukraine.

In market economy conditions, tax revenues to the state and local budgets are essential for the state to fulfill its functions and the main structure-forming component of the revenue part of the budgets. Table 4 summarizes the tax revenues of the special fund of the Consolidated Budget of Ukraine. Presently, in Ukraine, the tax sharing between the state and local budgets is such that, first, it does not promote the self-sufficiency of local authorities and financial independence from the state, and secondly, there is an excessive withdrawal of tax revenues from the regions and as the consequence there is a need for transfer regulation.

To the Special Fund of the Consolidated Budget of Ukraine, the largest amount of tax revenues in 2018 came from domestic taxes on goods and services. Revenues from taxes on international trade and 
external transactions over a space of three years increased by UAH 3.26 billion.

Table 4

Composition of tax revenues of the special fund of the Consolidated Budget of Ukraine, billion UAH

\begin{tabular}{|c|c|c|c|c|}
\hline & 2016 & 2017 & 2018 & $\begin{array}{c}\text { Absolute } \\
\text { variation } \\
2018 \text { from } \\
2016(+,-) \\
\end{array}$ \\
\hline Tax revenues & 5,690 & 36,79 & 42,69 & 37,00 \\
\hline $\begin{array}{l}\text { Income taxes, profits } \\
\text { taxes, market gains } \\
\text { taxes }\end{array}$ & & 2,990 & 1,15 & 1,15 \\
\hline Property taxes & 0,011 & 0,001 & 0,00 & $-0,01$ \\
\hline $\begin{array}{l}\text { Rental taxes and } \\
\text { payments for the use of } \\
\text { other environmental } \\
\text { resources }\end{array}$ & & & 0,18 & 0,18 \\
\hline $\begin{array}{l}\text { Domestic taxes on } \\
\text { goods and services }\end{array}$ & & 13,270 & 32,24 & 32,24 \\
\hline $\begin{array}{l}\text { Taxes on international } \\
\text { trade and external } \\
\text { transactions }\end{array}$ & & 1,640 & 3,26 & 3,26 \\
\hline $\begin{array}{l}\text { Separate local taxes } \\
\text { and fees }\end{array}$ & & & & 0,00 \\
\hline $\begin{array}{l}\text { Fees for fuel and } \\
\text { energy resources }\end{array}$ & & & & 0,00 \\
\hline Local taxes & $-0,001$ & 0,694 & & 0,00 \\
\hline $\begin{array}{l}\text { Other taxes and } \\
\text { charges }\end{array}$ & 5,680 & 18,190 & 5,87 & 0,19 \\
\hline
\end{tabular}




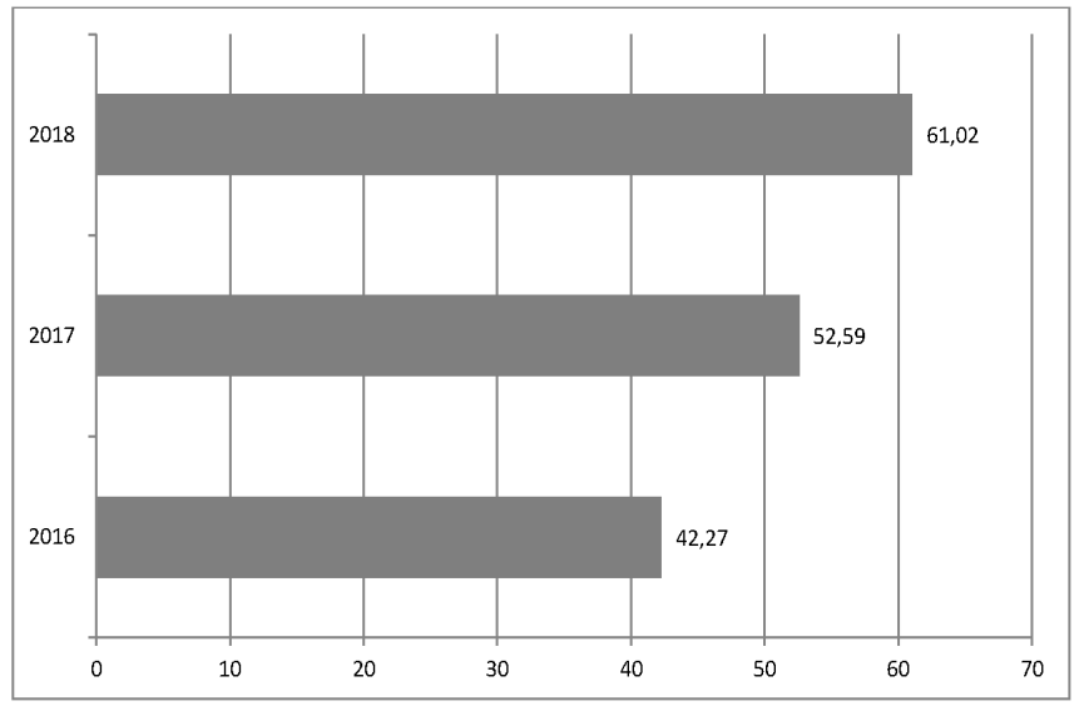

Fig. 1. Dynamics of local taxes in the general fund revenues of the Consolidated Budget of Ukraine, billion UAH

The economic and social development of any country depends largely on the development of its territories. This, in turn, requires adequate financial support through the formation of local budgets. Securing local government with stable and sufficient financial resources is the key to becoming a capable and efficient local authority. Moreover, without the financial autonomy of local budgets with its numerous components and taking into account the tax potential of each territory, it is impossible to build and develop an effective national economy ${ }^{8}$.

As a part of the general fund of the Consolidated Budget of Ukraine, revenues from local taxes have steadily increased over the three-year period. In 2018, their total amount was higher than in 2016 by UAH 18.75 billion.

${ }^{8}$ Податкова система: Навчальний посібник за заг. ред. І. С. Волохової, О. Ю. Дубовик. Харків: Видавництво «Діса плюс», 2019. 402 с. 
Table 5

Dynamics of local taxes of the general fund of the Consolidated

Budget of Ukraine, billion UAH

\begin{tabular}{|c|c|c|c|c|}
\hline & 2016 & 2017 & 2018 & $\begin{array}{l}\text { Absolute } \\
\text { variation } \\
2018 \text { from } \\
2016(+,-)\end{array}$ \\
\hline Property tax & 24,99 & 29,06 & 31,27 & 6,28 \\
\hline $\begin{array}{l}\text { Parking service fees } \\
\text { for vehicles }\end{array}$ & 0,07 & 0,08 & 0,10 & 0,03 \\
\hline Tourist tax & 0,05 & 0,07 & 0,09 & 0,04 \\
\hline $\begin{array}{l}\text { Fee for conducting } \\
\text { certain types of } \\
\text { business activities, } \\
\text { which is to be paid } \\
\text { before } 1 \text { January } 2015\end{array}$ & $-0,01$ & $-0,01$ & 0,00 & 0,01 \\
\hline Single tax & 17,17 & 23,39 & 29,56 & 12,39 \\
\hline Total & 42,27 & 52,59 & 61,02 & 18,75 \\
\hline
\end{tabular}

Revenues from the single tax to the general fund of the Consolidated Budget of Ukraine during 2016-2018 increased by UAH 12.39 billion. The increase in property tax revenues was also significant, which increased by UAH 6.28 billion.

Negative factors affecting the dynamics of local budget revenues are a slowdown of socioeconomic development of the country, rise in unemployment, the aggravation of inflation, the devaluation of the national currency, which have been recently observed in the country. In case of maintaining the heightened rates of growth of spending on government sector financing, lying under local authority's cognizance, the problem of revenue instability is very acute. 
Table 6

Structure of local taxes of the general fund of the Consolidated Budget of Ukraine, billion UAH

\begin{tabular}{|l|c|c|c|c|}
\hline \multicolumn{1}{|c|}{ from } & $\mathbf{2 0 1 6}$ & $\mathbf{2 0 1 7}$ & $\mathbf{2 0 1 8}$ & $\begin{array}{c}\text { Absolute } \\
\text { variation } \\
\mathbf{2 0 1 8} \text { from } \\
\mathbf{2 0 1 6}(+,-)\end{array}$ \\
\hline Property tax & 59,12 & 59,12 & 55,26 & $-3,87$ \\
\hline $\begin{array}{l}\text { Parking service fees } \\
\text { for vehicles }\end{array}$ & 0,15 & 0,16 & 0,15 & 0,00 \\
\hline Tourist tax & 0,14 & 0,13 & 0,13 & $-0,01$ \\
\hline $\begin{array}{l}\text { Fee for conducting } \\
\text { certain types of } \\
\text { business activities, } \\
\text { which is to be paid } \\
\text { before 1 January 2015 }\end{array}$ & $-0,03$ & $-0,03$ & $-0,01$ & 0,02 \\
\hline Single tax & 40,62 & 40,62 & 44,48 & 3,86 \\
\hline Total & 100 & 100 & 100 & 0,00 \\
\hline
\end{tabular}

The analysis of the structure of local tax revenues to the general fund of the Consolidated Budget of Ukraine shows that in 2018, $99.74 \%$ of these revenues were ensured at the cost of property tax and single tax. At the same time, the relative share of tax funds from the property tax decreased by $3.87 \%$, and from the single tax increased by $3.86 \%$.

\section{Determination of development prospects of Ukrainian taxation system}

The issue of local taxation is an important tool for the functioning and development of local government. As successful performance of functions and tasks entrusted to local governments is impossible without adequate financial support. The major source of 
revenues of local budgets should become own revenues, including local taxes and fees. That is why, the enhancement of the role of local taxes and fees and increase of their interest in composition of revenues is the principal direction of stabilization of local budgets and extension of the financial autonomy of the respective territories.

The local tax system should not only meet the needs of local budgets in the flow of funds, but also take into account the solvency margin of potential payers of taxes and fees. Consequently, in establishing the rates of local taxes and fees, and when introducing favorable terms of their levying, it should be simultaneously taken into account both aspects in their inextricable connection.

The peculiarity of the tax system in Ukraine in general and of the local tax system, in particular, is its inconsistency, which is primarily due to the instability of tax legislation. Consequently, in establishing taxes and fees at the local level, the authorities should take this specific feature into account and implement the principle of maximum mobility and flexibility ${ }^{9}$.

To increase the role of local taxes and fees, it is necessary to focus on a number of problems that exist in the local budgeting system. For example, they include an excess of administrative expenditures compared to revenues in such budgets, limitation of local authorities' ability to set and pay local taxes and fees, and the complexity of the taxation process. Well-organized local budgeting will promote the development of the region's well-being and improve the quality of life of the population, so studying the place of local taxes and fees plays an important role in developing a fair and efficient tax system in the country in accordance with the principles of a democratic system.

In recent years, changes in tax and budget legislation towards increase in income volume of local budgets at the expense of local taxes and fees have been implemented using methods such as

9 Динаміка податкового навантаження в Україні в контексті реалізації податкової реформи / за заг. ред. Т.І.Єфименко, А. М. Соколовскої. К.: ДННУ «Академія фінансового управління», 2013. 492 с. 
eliminating inefficient taxes and introducing new ones; extending taxable items; change in tax rates; widening the circle of taxpayers; tax regrouping (transfer of national taxes (single tax and land fee)) to the local level.

The main budget-forming local taxes in Ukraine have become a single tax and land fee. However, the disadvantages of the local taxation system are the low fiscal importance of local taxes and fees, the lack of legal bases for the functioning of the self-taxation system, the absence of a targeted local taxation system.

The national tax system in composition and structure is similar to the systems of developed European countries, since the tax issues are developed in accordance with the rules of European tax legislation, as well as aspects of GATT / WTO tax policy and other international economic organizations. However, unlike the countries of the European Community, the tax system of Ukraine is not an instrument of increasing the competitiveness of the state. It does not contribute to the growth of economic activity of incorporated and unincorporated businesses.

In the process of reforming the tax system in Ukraine, not only the level of tax burden but also the optimal combination of direct and indirect taxes is an important problem. If during the economic slack the role of indirect taxes is increasing, which makes it possible to consolidate and stabilize the tax base, then, during economic growth, on the contrary, the direct taxes have a dominant fiscal influence ${ }^{10}$.

Direct taxes are the basis of the tax systems of countries with advanced market economies because they have significant advantages over indirect ones. As it is well-known, direct taxes have almost no effect on prices, do not change the structure of demand, but reduce the income of payers and thus affect the volume of investment and consumer demand. The direct correlation between the amount of direct taxes and the amount of income contributes to increasing the state's

${ }^{10}$ Дубовик О. Ю. Гармонізація податкових систем в умовах глобалізації. Фінансова система України: проблеми та перспективи розвитку в умовах трансформації сочіально-економічних відносин. Севастополь, 2013. С. 25-27. 
ability to regulate economic processes and solve social justice at the expense of progressive tax rates. At the same time, direct taxes in fiscal terms are inferior to indirect taxes in the stability of revenues, in the uniform distribution of revenues in individual regions, in the existence of more favourable conditions for tax evasion. Indirect taxes, while more convenient for fiscal authorities from the standpoint of their levying, but their payment is burdensome on shoulders of the final consumer, so the prevalence of fair direct taxes will avoid such negative effects as impoverishment of the majority of the population, further decline in domestic production. The practice of developing tax systems in European countries testifies to the growing role of direct taxation, first and foremost, of income taxation of revenues. The growing tax culture and the awareness of direct taxpayers make it possible to ensure a steady flow of budget revenues and to use taxes as tools to stimulate scientific and technological progress, to increase employment, and even territorial development and so on. Nowadays, indirect taxes prevail in Ukraine, since in the conditions of low level of income of individuals and inadequate level of tax culture it is impossible to ensure that the structure of the tax system of direct taxes dominates. At the same time, national tax rates on personal income and corporate income tax are among the lowest in Europe, which should be an important prerequisite for attracting foreign investments, creating new jobs and increasing business activity.

In spite of the fact that during 2012-2018 Ukraine has improved its rating on the simplicity of the tax system, the national tax system remains complex and unfavourable for doing business. Local businesses are required to spend much more time (327.5 hours) in preparing and filing tax returns and paying taxes than in EU countries.

In terms of this, Ukraine is in the 159th place in the world, where the average time for preparation of reporting is 240 hours, when in EU countries it is 161 hours. According to the report of the Business Ombudsman Council, in 2016, 868 complaints were received from companies against the work of state bodies, and the largest number (49\%) of complaints from Ukrainian business were received regarding the work of the State Fiscal Service bodies. The low level of trust to 
the fiscal authorities is evidenced by the results of a survey conducted by the TNS Research Company commissioned by the National Reform Council's Project Office, according to which only $17 \%$ of citizens trust the employees of the State Fiscal Service. What is more, according to the results of a monthly poll by this company, $72 \%$ of citizens surveyed did not feel the positive fallout from tax reforms ${ }^{11}$. The level of tax burden in Ukraine is assessed in diverse ways. Almost all investment climate experts find it unfavourable because the taxation of the real sector of economy is overburdensome. It suppresses the processes of economic reproduction, and the enterprise can operate at a profit, usually only with the concealment of its income from taxation. The majority of entrepreneurs also believe that the current economic situation in our country does not contribute to the development of entrepreneurial activity, that the heavy burden of taxes leads to such negative consequences as the decline of business activity of business entities, shadowing economy, the outflow of national capital abroad. As a result, budget revenues are reducing and social tensions are increasing in society. In fact, today the taxation system is one of the main obstacles to the effective competitive development of our country's economy.

In order to ensure the development of national economy and growth of well-being of the citizens, the taxation system of Ukraine must change considering the national and international experience, the demands of time and priorities of national economy development.

Significant shortcomings in the functioning of the national taxation system include the suboptimal correlation of direct and indirect taxes, the imperfection of the legal framework, complex procedures for tax administration and non-transparent control of their application, insufficient work of tax authorities. Improving the efficiency of Ukraine's taxation system requires strengthening of the stimulating role of direct taxes; simplifying tax administration

11 Ярема Б.П., Ролько А.В. Сучасна податкова система України: проблеми та перспективи розвитку. Причорноморські економічні студіï. 2018. Випуск 34. С. 171-175. 
procedures and increasing transparency in control of their appliance; increasing the efficiency of work of controlling bodies with strengthening of control over taxpayers ${ }^{12}$.

The main provisions, which should be taken into account in the process of the further development of Ukrainian taxation system, are as follows: the taxation system must have an investment and social orientation; changes in the taxation system should be made in parallel with reforms in the system of remuneration, pensions, improvement of the social sphere; expanding the use of non-tax forms and methods of mobilizing budget revenues; the tax taxation should be based on direct taxes; indirect taxes should be used only in the form of excise duties to limit the consumption of certain types of goods, the ability of the manufacturer-monopolist to obtain unreasonably high incomes, as well as to imposition of taxation to luxury commodities and protect his own manufacturer; the list of taxes for environmental pollution, such as littering public places, needs to be increased; the taxation system must meet the requirements of simplicity, transparency and plainless; the tax must be charged at a convenient time for the payer and in an appropriate way; extending the rights of self-governing bodies in the field of taxation ${ }^{13}$.

It should be noted that in the process of reforming the taxation system in Ukraine, an important problem is not only the level of tax burden, but also the optimal combination of direct and indirect taxes. While indirect taxes are convenient for fiscal authorities to collect, they are burdensome for the final user. That is why, the prevalence of proper direct taxes will avoid the negative consequences, such as the decline in the standard of living of the population, the further decline of Ukrainian production, which is not able to compete with the

12 Радова О.В. Оподаткування в Україні: нововведення, тенденції та проблеми розвитку. Науковий вісник Ужгородського національного університету. 2018. Випуск 20, частина 3.

13 Щербань О.Д. Напрями удосконалення формування доходів місцевих бюджетів. Вісник економіки транспорту і промисловості. 2013. № 41. С. 74-79. 
products of foreign producers ${ }^{14}$. The main task of reforming the taxation system should be the creation of the preconditions for economic growth by unlocking entrepreneurial potential and the facilitation of implementation of the national competitive advantages. At the structural level, the reform should facilitate accelerated economic recovery by accelerating the process of growth of new businesses and industries. Regulation of modern economic relations in Ukraine requires a flexible tax policy of the state that would allow optimally linking the interests of the state with the interests of entrepreneurship. Reforms that reduce tax pressures on household incomes can also help to bring in some income of individuals from the cold and more effectively differentiate taxpayers. In order to create an optimal taxation system, it is necessary to be guided by such basic principles as social justice, economic efficiency, stability and flexibility. Therefore, the prospects for further positive changes in the taxation system are the specification of measures to reform Ukraine's tax policy to reduce the tax burden, simplification of tax administration procedures and improvement of the tax control mechanism.

\section{CONCLUSIONS}

Reforming the taxation system begins with the competent introduction of principle of taxation, the tax legislation must be constructed hereon. To disrupt and form new regulatory framework is not practical, it is necessary to make allowances in accordance to the changes in tax area. Current tax law can be described as contradictory and unsustainable. The reforming taxation system of Ukraine should take the form of an optimal combination of fiscal efficiency and regulatory mechanisms for economic growth, reflected in the principles of taxation. Key directions of modernization of the existing tax system should be reduced to: modulated reduction and equalization of tax pressure between payers of different categories without taking

14 Крисоватий А.І. Теоретико-організаційні домінанти та практика реалізації податкової політики в Україні. Тернопіль: Карт-бланш, 2015. 371 с. 
into account their type of activity; introduction of unfailing monitoring of the expenditure level at manufacturing enterprises; creation of an enabling tax environment for the active involvement of foreign investors; cost reduction for the administrative component of taxation; streamlining tax rates and levelling them to European standards. The reforming the taxation system should be based on the principle of fiscal efficiency, in other words the formation of the revenue at the appropriate level, which will ensure the fulfillment of its functions by the state; achieving equal tax burdens, equal tension between taxpayers, social justice, stability and flexibility are the key to the efficiency of the taxation system. A balance of these indicators will allow ensuring the economic growth of Ukraine not only at a certain stage, but also in the long run. Thus, the effectiveness of the taxation system is reflected through the application and operation of a tax mechanism that takes into account the specific economic situation in the country and the role of the state in regulating social and economic processes. In order to achieve the effectiveness of tax regulation of the economy, a mechanism for using specific tax forms and management methods should be developed. Adoption of the Tax Code of Ukraine contributed to the reduction of tax pressure by abolishing unreasonable benefits and broadening of the tax base. It, in its turn, increased budget revenues, as well as enabled solving complex social issues.

\section{SUMMARY}

This paper presents the conducted analysis of the contemporary state of tax revenues of consolidated budget of Ukraine. It is determined that to ensure the development of the state economy and growth of well-being of the country, the Ukrainian taxation system should be changed, taking into consideration the local and global experiences, the demands of times and national economy development priorities. It is established that the current tax legislation may be defined as contradictory and unsustainable. Reforming the taxation system of Ukraine should be presented in the form of an optimal combination of fiscal efficiency and control mechanisms for economic growth, reflected in the principles of taxation. Key directions of 
modernization of the existing tax system should be reduced to: modulated reduction and equalization of tax pressure between payers of different categories without taking into account their type of activity; introduction of unfailing monitoring of the expenditure level at manufacturing enterprises; creation of an enabling tax environment for the active involvement of foreign investors; cost reduction for the administrative component of taxation; streamlining tax rates and levelling them to European standards.

\section{REFERENCES}

1. Курносова К.В. Напрями реформування доходної бази місцевого самоврядування. Наукові пращуі НДФІ. 2007. 3(40). C. 25-33.

2. Вишневський В., Вєткін А. Відхід від сплати податків: теорія і практика. Донецьк: Монографія ІНАН України, Інститут економіки промисловості, 2003. - 10, 62 с.

3. Малишкін О. I. Коефіцієнт податкового навантаження на мікрорівні: розрахунок та застосування. Бухгалтерський облік $i$ aудит. 2015. № 1. С. $18-25$.

4. Податковий кодекс України: Закон України від 02.12.2010 № 2755-VI URL: https://zakon.rada.gov.ua/laws/show/ 2755-17

5. Макогон В.Д. Формування доходів місцевих бюджетів у зарубіжних країнах. Наукові праизі НДФІ. 2008. № 1 (42) С. 56-66.

6. Виконання Державного бюджету / сайт Державної казначейської служби України URL: http://www.treasury.gov.ua/ maitalog/list?Currdir=311513

7. Жиляєва Н. Фіскальна політика держави в період світової економічної кризи та напрями підвищення іï ефективності. Вісник Київського національного університету ім. Тараса Шевченко. 2010. № 119. С. 49-51.

8. Податкова система: Навчальний посібник за заг. ред. I. С. Волохової, О. Ю. Дубовик. Харків: Видавництво “Діса плюс", 2019. 402 с. 
9. Динаміка податкового навантаження в Україні в контексті реалізації податкової реформи / за заг. ред. T. І. Єфименко, А. М. Соколовскої. К.: ДННУ “Академія фінансового управління", 2013. 492 с.

10. Дубовик О. Ю. Гармонізація податкових систем в умовах глобалізації. Фінансова система України: проблеми та перспективи розвитку в умовах трансформачії сочіальноекономічних відносин. Севастополь, 2013. С. 25-27.

11. Ярема Б.П., Ролько А.В. Сучасна податкова система України: проблеми та перспективи розвитку. Причорноморські економічні студіï. 2018. Випуск 34. С. 171-175.

12. Радова О.В. Оподаткування в Україні: нововведення, тенденції та проблеми розвитку. Науковий вісник Ужгородського національного університету. 2018. Випуск 20, частина 3.

13. Щербань О.Д. Напрями удосконалення формування доходів місцевих бюджетів. Вісник економіки транспорту $i$ промисловості. 2013. № 41. С. 74-79.

14. Крисоватий А.І. Теоретико-організаційні домінанти та практика реалізації податкової політики в Україні. Тернопіль: Карт-бланш, 2015. 371 с.

Information about the author: Dmytro Mishchenko, Doctor of Sciences (Public Administration), Professor at the Department of State, Local and Corporate Finance, University of Customs and Finance 2/4, Volodymyra Vernadskoho str., Dnipro, 49000, Ukraine 
DOI https://doi.org/10.36059/978-966-397-162-9/137-159

\section{USE OF MATHEMATICAL ECONOMIC MODELS FOR EFFECTIVE AND REASONABLE MANAGEMENT DECISION-MAKING TO ENFORCE THE PERFORMANCE OF THE SOCIAL FUNCTION BY THE STATE}

\section{Viktor Ventsel}

\section{INTRODUCTION}

Civilizational development of social relations has led to the fact that the state became the main form of life organisation of a specific set of individuals. As of today, the state embodies a complex system of interconnected institutions that manage society. As a result of evolutionary processes, social function became one of the main functions of the state. Its introduction and priority role were determined by the formation of the humanocentrism idea in the functioning of the state. That is, the main purpose of the state is to take care of the person as the highest social value. Modern state is trying to commit itself to creating conditions for ensuring the proper living standard of its citizens, their humanitarian and spiritual development, ensuring the protection and support of vulnerable social groups, creating conditions for conflict-free coexistence of different social groups, as well as providing protection from various external and internal threats. An effective social policy of the state requires adequate resources. In this context, the main task of the state is fair distribution of available resources, allocating them for the implementation of various social programs, which are aimed at ensuring specific living standards of the citizens and mitigation of the social inequality consequences, which is an objective aspect in the life of any society. In the process of evolution, economic and social development, there was a gradual expansion of the social welfare criteria, the amount of the first priority needs of the people, as well as the minimum level of material and non-material benefits needed for a normal life. Therefore, as of today, a rather high level of minimum 
welfare, which the state should provide for its citizens has been formed. The global trend indicates a steady increase in social expenditures. In 2018, the average level of social expenditures in OECD countries was $20.1 \%$ of $\mathrm{GDP}^{1}$, while in 1980 the level of social expenditures in GDP was $14.4 \%^{2}$. In Ukraine, this figure (the results of 2018 ) is $18 \%$ of $\mathrm{GDP}^{3,4,5}$.

At the same time, the financial capacity of the state is growing at a slower pace than the needs of society. In addition, globalisation processes influence the possibility of implementing the social policy of the state. National governments must adhere to specific international obligations and take into account global socio-economic processes. Therefore, currently, we have a situation when the state is not able to fulfil its social obligations towards its citizens on a full scale. It is important to identify and establish correlations between the social function of the state and the resources for its implementation. Social expenditures are one of the most resource-demanding budget articles. One of the main tasks of public authorities is to optimally determine the amount of social expenditures based on available resources. The rate of social expenditures should be sufficient to provide citizens with

1 OECD (2019), Social spending (indicator). doi: 10.1787/7497563b-en Retrieved from: https://stats.oecd.org/Index.aspx?datasetcode=SOCX_AGG\# (Accessed on 02 November 2019)

2 OECD.Stat (2019). Retrieved from: https://stats.oecd.org/Index.aspx? datasetcode=SOCX_AGG\# (Accessed on 02 November 2019)

${ }^{3}$ Pension Fund of Ukraine (2019). Zvit pro robotu ta vykonannia biudzhetu pensiinoho fondu Ukrainy u 2018 rotsi [Report on the operation and implementation of the budget of the Pension Fund of Ukraine in 2018]. Retrieved from: https://www.pfu.gov.ua/content/uploads/2019/03/Zvit_2018_21_03_2019.pdf (accessed 02 November 2019)

${ }^{4}$ Financial and economic analysis office in the VRU (2019). Analiz diialnosti fondu sotsialnoho strakhuvannia. [Analysis of social insurance fund activity]. Retrieved from: https://feao.org.ua/wp-content/uploads/2019/04/2019-04-17-fss.pdf (accessed 02 November 2019)

5 State Treasury Service of Ukraine (2019). Richnyi zvit pro vykonannia Derzhavnoho biudzhetu Ukrainy za 2018 rik [Annual report on execution of the State Budget of Ukraine for 2018]. Retrieved from: https://www.treasury.gov.ua/ua/ file-storage/richnij-zvit-pro-vikonannya-derzhavnogo-byudzhetu-ukrayini-za-2018-rik (accessed 02 November 2019) 
adequate state support and, at the same time, the rate of social expenditures should not be significant enough to have a negative impact on the financial and economic stability of the state.

Mathematical modelling in economics is one of the tools that should be used to improve management quality and reasonable determination of state social expenditures.

Currently, the use of mathematical models is not very common and due attention is not paid to this tool. The current state of economic and mathematical studies of the social development processes in Ukraine is limited to mainly theoretical developments. Real models that would enable performing forecasts and simulation calculations in the operational mode for analytical substantiation of strategic and tactical tasks in different fields of state formation, weren't properly distributed $^{6}$.

\section{Mathematical modelling in economics as a tool for analysis and management decision-making}

Mathematical modelling in economics is a description of economic processes and phenomena in the form of a mathematical model. The practical tasks of modelling are the analysis of economic entities (processes), economic forecasting (predicting the development or future state of economic or business processes) and management decision-making. However, it should be borne in mind that data obtained from the economic and mathematical model may not always be unconditionally used as ready-made management decision. Sometimes it is used as one of the important advisory tools along with other management decision-making tools. This is because the socioeconomic processes are extremely complex and require careful study and elaboration, as well as the involvement of purely human qualities. It should also be taken into account that the modelling process goes

${ }^{6}$ Vlasiuk O. S. (2011) Ekonomiko-matematychne modeliuvannia protsesiv sotsialno-ekonomichnoho rozvytku Ukrainy [Economic and mathematical modeling of the processes of social and economic development of Ukraine]. Kyiv: SESI "Academy of Financial Management" (in Ukrainian), p. 11 
deep into the general cognitive process. The process of mathematical modelling in economics consists of specific steps: identification of the object; model specification; identification and evaluation of the model parameters; identifying dependencies between the parameters. This cycle is repeated multiple times and during this process the knowledge about the object of study is expanded and refined, and the initial model is gradually improved. The shortcomings (due to insufficient information about the object) that were detected during the first modelling cycle can be eliminated in the following cycles. The most common disadvantages include: insignificant variables in the model; failure to account for significant variables in the model; parameters of the model are not accurate enough; flaws in the structure of the model (for instance, incorrect determination of dependencies between variables) ${ }^{7}$. Thus, a great potential for self-development is embedded in the modelling methodology due to periodic improvements.

In the scientific environment of Ukraine there is a sufficient number of studies that examine mathematical methods and models, aimed at solving the issues of functioning of economic and social processes.

It is worth mentioning the approach suggested by Yu. Kharazishvili and O. Liubich, that provides a systematic approach to the construction of the macroeconomic model of Ukraine. The essence of the model is that it is based on the overall economic balance in the country, which is the result of aggregate demand and aggregate supply interaction. This model examines the national economy as a whole, assuming that the price level affects economic activity. As a result of the simulation, the authors conclude that inflation (consumer price index) is the result of interaction of all economic entities in all markets and not the result of change (increase or decrease) of money supply ${ }^{8}$.

7 Lopatnikov L. I. (2003) Ekonomiko-matematicheskiy slovar': Slovar' sovremennoy ekonomicheskoy nauki [Economics and Mathematics Dictionary: Dictionary of Modern Economics]. Moscow: Delo (in Russian)

8 Kharazishvili Yu. M., Liubich O. O. (2006) Systemne modeliuvannia sotsialno-ekonomichnoho rozvytku Ukrainy [System modeling of social and economic development of Ukraine]. Banking magazine, no. 3, pp. 46-65 
Scientist A. Shyian built a mathematical model to describe the impact of public institutions and corruption on the implementation efficiency of economic projects ${ }^{9}$. This model was formed taking into account the fact that the ruling circles are interested in receiving rent from the use of national resources, which, in turn, leads to corruption and issues due to the inconsistency of the elite's goals with the development goals of the society.

In this context, it is of utmost importance for Ukraine to transform post-Soviet public institutions for their efficient functioning in the process of economic transformation, that is, the formation of market mechanisms instead of planned administrative management of economic processes. At this stage, one of the main tasks is not the unconditional implementation of borrowed rules, procedures, mechanisms, but the formation of own economic and social relations system that meets the national conditions of socio-economic, historical and cultural development, mindset, geopolitical position. In this regard, the efficient functioning of public institutions is important for the development of the Ukrainian economy. A. Shyian developed a mathematical model that showed that the Ukrainian economic losses due to institutional shortcomings could be compared to the economic losses due to corruption, namely, institutional losses can make 20-30\% of $\mathrm{GDP}^{10}$. Thereby, the reorganisation of public institutions can be carried out using internal resources available in the Ukrainian economy. Mathematical model developed by A. Shyian provides an opportunity to choose the best way to transform public institutions towards increasing their economic efficiency ${ }^{11}$.

${ }^{9}$ Shyian A. A. (2008), Matematychna model vplyvu suspilnykh instytutiv na efektyvnist ekonomiky Ukrainy [Mathematical model of influence of public institutes on efficiency of economy of Ukraine]. Visnyk of Vinnytsia Polytechnical Institute, no. 2, pp. 19-23

${ }^{10}$ Shyian A. A. (2008), Matematychna model vplyvu suspilnykh instytutiv na efektyvnist ekonomiky Ukrainy [Mathematical model of influence of public institutes on efficiency of economy of Ukraine]. Visnyk of Vinnytsia Polytechnical Institute, no. 2, pp. 19-23

${ }^{11}$ Shyian A. A. (2008), Matematychna model vplyvu suspilnykh instytutiv na efektyvnist ekonomiky Ukrainy [Mathematical model of influence of public institutes 
At the modern stage, one of the most important aspects of the functioning of the state is the social area, which provides for a comprehensive raising of the living standards of the population (from a material perspective, as well as cultural, spiritual development, health care, psychological care, etc.). Social aspects in public life are not only related to the protection of vulnerable social groups, they are also linked to the development of economic potential since they are directly related to the person that is the main productive force. The functioning of the social sector requires adequate financial support. N. Pihul, O. Liuta and A. Boyko formed a mathematical model which determined additional volumes of budgetary and extra-budgetary financing to ensure proper implementation of social functions by the state $^{12}$. In the course of the research, the authors analysed the volume of budget financing of the social sector, determined the volume of extrabudgetary financing of the social sector, compared the quantitative indicators of the human development index with the volumes of budgetary and extrabudgetary financing of the social sector of Ukraine. The final stage of the study was the calculation of the amount of money needed to ensure incentives for quality development of the social sector of Ukraine ${ }^{13}$.

Modelling of economic and social processes is an effective and promising tool for planning public expenditures, social policy development and reasonable management decision-making. Therefore, the research of issues of the creation of mathematical and economic models of socio-economic development of society requires more detailed study.

on efficiency of economy of Ukraine]. Visnyk of Vinnytsia Polytechnical Institute, no. 2, pp. 19-23

12 Pihul N., Liuta O., Boiko A. (2015), Finansove zabezpechennia sotsialnoi sfery v Ukraini [Financial support of social sphere in Ukraine]. Herald of the National Bank of Ukraine, no. 1 (227), pp. 30-35

${ }^{13}$ Pihul N., Liuta O., Boiko A. (2015), Finansove zabezpechennia sotsialnoi sfery v Ukraini [Financial support of social sphere in Ukraine]. Herald of the National Bank of Ukraine, no. 1 (227), pp. 30-35 


\section{Features of the correlation-regression method}

Budget, as a centralised fund of financial resources, through which the support and development of socially important sectors and areas are carried out, is the most effective tool for the influence of state on social policy ${ }^{14}$. We believe that mathematical modelling in economics should be used more actively in the implementation of the social function by the state, particularly in the process of objectively determining the amount of social expenditures from the budget, in identifying the relationship between the economic development indicators of the state and its social policy.

Table 1 presents some indicators that characterise budget and social policies of Ukraine and are considered by the author as the basis for building a mathematical economic model for analysing and forecasting economic development and the volume of budget expenditures for financing specific sectors of the socio-humanitarian area.

Mathematical economic model can be built by correlationregression method, principal components analysis ${ }^{15}$ and the method of statistical equations of dependencies ${ }^{16}$.

The economic process develops under the influence of many different factors. Generally, the mathematical economic model of this process is written on the basis of the following considerations:

Suppose the following statistical data was obtained from observations:

$y_{1}, x_{10}, x_{11}, x_{12}, \ldots, x_{1 m}-$ at the first moment of time;

$y_{2}, x_{20}, x_{21}, x_{22}, \ldots, x_{2 m}-$ at the second moment of time;

14 Ventsel V. (2018), Biudzhetna polityka yak osnovnyi instrument zabezpechennia derzhavoiu sotsialnoi funktsii [Budget policy as the main instrument for providing state social function]. Public Administration: Theory and Practice (electronic journal), no. 2, pp. 24-35. Retrieved from: http:/www.e-patp.academy.gov.ua/pages/ dop/23/files/6bc2f41d-f34f-4ee3-8d43-dcbd1d0a6204.pdf (accessed 02 November 2019)

${ }^{15}$ Kuliavets V. O. (2014), Prohnozuvannia rozvytku enerhorynku rehionu: Navchalnyi posibnyk [Forecasting the development of the region's energy market: A textbook]. Zhytomyr: ZhVI DUT (in Ukrainian), p. 155

${ }^{16}$ Kulynych O. I. (2003), Ekonometriia: Navchalnyi posibnyk. [Econometrics: A Textbook]. Khmelnytskyi: Podillia (in Ukrainian), p. 78 
$y_{n}, x_{n 0}, x_{n 1}, x_{n 2}, \ldots, x_{n \mathrm{~m}}-$ at the $n$ moment of time.

Here $y_{\mathrm{i}}$ denotes the value of the indicator, $x_{n m}$ - value of the factors, $n$ - number of observations (sample size), $m$ - number of factors.

Table 1

Basic indicators of economic and social development of Ukraine

\begin{tabular}{|l|l|c|c|c|c|c|c|c|c|c|c|c|}
\hline \multicolumn{3}{|l}{ Year } & $\mathbf{2 0 0 9}$ & $\mathbf{2 0 1 0}$ & $\mathbf{2 0 1 1}$ & $\mathbf{2 0 1 2}$ & $\mathbf{2 0 1 3}$ & $\mathbf{2 0 1 4}$ & $\mathbf{2 0 1 5}$ & $\mathbf{2 0 1 6}$ & $\mathbf{2 0 1 7}$ & $\mathbf{2 0 1 8}$ \\
\hline Factor & $\begin{array}{l}\text { Subsistence } \\
\text { minimum }\end{array}$ & $\mathrm{x} 1$ & 701 & 875 & 953 & 1095 & 1176 & 1253 & 1330 & 1544 & 1700 & 1853 \\
\hline Factor & $\begin{array}{l}\text { Minimum } \\
\text { wage }\end{array}$ & $\mathrm{x} 2$ & 744.0 & 922.0 & 1044.0 & 1134.0 & 1218.0 & 1298.0 & 1378.0 & 1600.0 & 3200.0 & 3723.0 \\
\hline Factor & Health care & $\mathrm{x} 3$ & 35.6 & 44.8 & 4.0 & 58.5 & 61.6 & 67.2 & 71.0 & 75.5 & 102.4 & 115.9 \\
\hline Factor & Education & $\mathrm{x} 4$ & 66.8 & 79.8 & 86.3 & 101.6 & 105.6 & 100.1 & 114.2 & 129.4 & 177.9 & 210.0 \\
\hline Factor & Defence & $\mathrm{x} 5$ & 9.7 & 11.4 & 13.2 & 14.5 & 18.8 & 27.4 & 52.0 & 59.4 & 74.4 & 97.0 \\
\hline Factor & $\begin{array}{l}\text { Social } \\
\text { protection }\end{array}$ & $\mathrm{x} 6$ & 78.8 & 104.5 & 105.4 & 125.3 & 145.1 & 138.0 & 176.3 & 258.3 & 285.8 & 309.4 \\
\hline Indicator & $\begin{array}{l}\text { Gross } \\
\text { Domestic } \\
\text { Product }\end{array}$ & $\mathrm{y}$ & 947.0 & 1079.3 & 1300.0 & 1404.7 & 1465.2 & 1856.9 & 1988.5 & 2385.4 & 2983.9 & 3358.7 \\
\hline
\end{tabular}

Sourse: own compilation based on data of the State Treasury Service of Ukraine $^{17}$ and the State Statistics Service of Ukraine ${ }^{18}$.

Introduce the fictitious factor $x_{0}$, which value for all moments of time we take equal to one, that is, $x_{i 0} \equiv 1$, where $i=1,2, \ldots, n$. Then a linear multifactor model can be written ${ }^{19}$ the following way:

$$
y_{i}=b_{0} x_{i 0}+b_{1} x_{i 1}+b_{2} x_{i 2}+\ldots+b_{m} x_{i m}+\varepsilon_{i},(2.1)
$$

where $b_{p}(p=0,1,2, \ldots ., m)$ - parameters of the model;

$\varepsilon$-stochastic (random) value.

We use matrix notation as

17 State Treasury Service of Ukraine. Retrieved from: https://www.treasury.gov.ua/ua/file-storage/vikonannya-derzhavnogo-byudzhetu (accessed 02 November 2019)

18 State Statistics Service of Ukraine. Retrieved from: http:// www.ukrstat.gov.ua/ (accessed 02 November 2019)

19 Nakonechnyi S. I., Tereshchenko T. O., Romaniuk T. P. (2000), Ekonometriia: Pidruchnyk [Econometrics: A textbook]. Kyiv: KNEU (in Ukrainian), p. 79 


$$
X=\left(\begin{array}{ccccc}
x_{10} & x_{11} & x_{12} & \ldots & x_{1 m} \\
x_{20} & x_{21} & x_{22} & \ldots & x_{2 m} \\
\cdot & \cdot & . & \ldots & \cdot \\
x_{i 0} & x_{i 1} & x_{i 2} & \ldots & z_{i m} \\
\cdot & \cdot & . & \ldots & \cdot \\
x_{n 0} & x_{n 1} & x_{n 2} & \ldots & x_{n m}
\end{array}\right) \quad Y=\left(\begin{array}{c}
y_{1} \\
y_{2} \\
\ldots \\
y_{i} \\
\ldots \\
y_{n}
\end{array}\right) ; \quad b=\left(\begin{array}{c}
b_{0} \\
b_{1} \\
\ldots \\
b_{j} \\
\ldots \\
b_{m}
\end{array}\right) ; \quad \varepsilon=\left(\begin{array}{c}
\varepsilon_{1} \\
\varepsilon_{2} \\
\ldots \\
\varepsilon_{i} \\
\ldots \\
\varepsilon_{n}
\end{array}\right),
$$

where $X, Y, b, \varepsilon$ - matrix of factors, indicator, parameters and margins (deviations) of the model respectively.

Then the equation (2.1) for all moments of time points can be represented as

$$
Y=X b+\varepsilon, Y^{*}=X b
$$

where $Y^{*}$ - matrix of the indicator values obtained as a result of forecasting (theoretical data);

$\varepsilon=Y-Y^{*}-$ matrix of deviations between the statistical data and the data obtained from the constructed model.

According to the method of least squares, the model parameters are determined ${ }^{20,21}$ by the formula

$$
b=\left(X^{T} X\right)^{-1} X^{T} Y \text {, }
$$

where the symbols ${ }^{T}$ and ${ }^{-1}$ respectively indicate the operation of transposition and inversion of the matrix.

20 Kuliavets V. O. (2009), Prohnozuvannia sotsialno-ekonomichnykh protsesiv: Navchalnyi posibnyk dlia studentiv ekonomichnykh spetsialnostei vyshchykh navchalnykh zakladiv [Predicting socio-economic processes: A textbook for students of economic specialties of higher education.]. Kyiv: Kondor (in Ukrainian)

${ }^{21}$ Nakonechnyi S. I., Tereshchenko T. O., Romaniuk T. P. (2000), Ekonometriia: Pidruchnyk [Econometrics: A textbook]. Kyiv: KNEU (in Ukrainian), p. 91 
The predicted value of the $y_{n}$ indicator is calculated by the formula

$$
y_{n}=X_{n}^{T} b,
$$

where $X_{n}$ - matrix of predicted values of factors.

To build a correlation-regression model we need to:

- detect and eliminate multicollinearity;

- detect and eliminate abnormal levels;

- detect and eliminate seasonal component;

- identify, whether an economic indicator has a tendency in statistical data;

- select the type of previous models;

- reduce nonlinear models to linear models and build them;

- determine the quality of the pre-built models and select the best one;

- determine the compliance of the selected best model with statistical data;

- check that the preconditions for building an adequate model are fulfilled;

- use the selected model for forecasting the economic process under study.

Before conducting correlation-regression analysis of multidimensional time series, it is necessary to identify and eliminate the main tendency and multicollinearity from the studied series. Multicollinearity in the series of dynamics can lead to an error in the estimation of the relationship using the correlation-regression analysis ${ }^{22}$ due to distortion of the real density between the levels of the series. One of the simplest ways to eliminate multicollinearity is to

22 Kuliavets V. O. (2009), Prohnozuvannia sotsialno-ekonomichnykh protsesiv: Navchalnyi posibnyk dlia studentiv ekonomichnykh spetsialnostei vyshchykh navchalnykh zakladiv [Predicting socio-economic processes: A textbook for students of economic specialties of higher education.]. Kyiv: Kondor (in Ukrainian), p. 120 
exclude one of the factors that has a correlation dependency with another factor from further processing.

However, in economic research there is often a situation where there is a mutual correlation dependency between all factors. In addition, often a factor that correlates with other factors significantly affects the indicator and eliminating it will significantly impair the quality of the model. Therefore, principal component analysis ${ }^{23}$ is used to build a multifactor model of regression, which enables to assess the parameters of models that include multicollinearity factors.

Economic or social phenomena can be characterised by a large number of features. Therefore, the analysis of the impact of the associations between these features is rather complicated. Considering this, there is a need for consolidation (or compression) of information, that is, the description of an object or phenomenon is made using extended indicators or the so-called principal components ${ }^{24}$. The principal component analysis is one of the main ways to reduce the dimension of data with the least loss of data and information. The starting element here is the correlation matrix on the basis of which the values of the observed features are analysed

$$
R_{\kappa}=\left(\begin{array}{cccc}
r_{11} & r_{12} & \ldots & r_{1 m} \\
r_{21} & r_{22} & \ldots & r_{2 m} \\
\ldots & \ldots & \ldots & \ldots \\
r_{n 1} & r_{n 2} & \ldots & r_{n m}
\end{array}\right)
$$

Properly selected features of the correlation model are usually closely related. These links allow having the information about the factor on the basis of another factor and this gives reason to eliminate one of them. The idea of considering one feature on the basis of

23 Nakonechnyi S. I., Tereshchenko T. O., Romaniuk T. P. (2000), Ekonometriia: Pidruchnyk [Econometrics: A textbook]. Kyiv: KNEU (in Ukrainian), p. 135

24 Opria A. T. (2017), Statystyka. Navchalnyi posibnyk [Statistics. A textbook]. Kyiv: Tsentr uchbovoi literatury (in Ukrainian) 
another is at the heart of the principal component analysis ${ }^{25}$. The downsides of the principal component analysis are the high complexity of calculations and the inaccuracy of forecasting due to elimination of principal components that correspond to small values.

\section{Using the method of statistical equations of dependencies for the analysing economic and social phenomena}

An important task in studying the relationship between economic phenomena is to determine their essence based on knowledge of the quality characteristics of the phenomena, their relationships, similarities and differences ${ }^{26}$. Here the most important properties and reasons that determine their stability must be selected from the population.

Changing the values of factors has different effects on the process of economic activity. When studying the relationship between indicators and various factors of economic activity, it is necessary to take into account that their interdependence is caused by the interconnected influence of specific phenomena on others, as well as the fact that a particular phenomenon develops under the influence of many other phenomena. Therefore, the main methods for assessing the relationships and dependencies are regression and correlation analysis.

The most common equations of regression analysis are the straight line, hyperbolic curve, parabolic curve, exponential curve, logarithmic function, S-curve, etc.

However, econometric models based on regression and correlation analysis have several drawbacks ${ }^{27}$.

1. The interpretation of the regression analysis results depends on understanding the content of regression equation parameters,

25 Opria A. T. (2017), Statystyka. Navchalnyi posibnyk [Statistics. A textbook]. Kyiv: Tsentr uchbovoi literatury (in Ukrainian)

${ }^{26}$ Kulinich E.I. (2001), Ekonometriya [Econometrics]. Moskva: Finansy i statistika (in Russian), p. 19

${ }^{27}$ Kuliavets V. O. (2014), Prohnozuvannia rozvytku enerhorynku rehionu: Navchalnyi posibnyk [Forecasting the development of the region's energy market: A textbook]. Zhytomyr: ZhVI DUT (in Ukrainian), p. 27 
obtained by the method of least squares. In the one-factor linear equation, the regression coefficient $\mathrm{Y}$ on $\mathrm{X}$ determines the average change in the indicator value, when the factor value changes by one unit. This is not always possible. For instance, analysing the dependence of labour productivity on the impact of the employees' technical training level and their work experience (according to annual data) it is difficult to make the conclusion about how the level of labour productivity would change with the change of employees' technical training level, if the their work experience remains the same. The task becomes much more complicated for nonlinear models. For example, when studying the output of an enterprise depending on time on the basis of a simple exponent $y_{x}=k b_{0}^{b_{1}^{x}}$ or logistic curve $y_{x}=\frac{k}{1+b_{0} b_{1}^{-x}}$ it is almost impossible to formulate the economic sense of the regression coefficient. Therefore, it is not always possible to provide an economic interpretation of the regression coefficient of the models.

2. Intercept term of the regression equation should reflect the average effect of all unaccounted factors. In many cases, however, it makes no economic sense, especially when its value is negative. So, for instance, when studying the dependence of the wage level (indicator $\mathrm{Y}$ ) on the number of hours worked (factor $\mathrm{X}$ ), at $\mathrm{X}=0$ the wage level is equal to the value of the intercept term of regression, which is basically impossible. Thus, in many cases, the intercept term of regression makes no economic sense.

3. When determining the parameters of a multifactor regression using the method of least squares, it is important to choose the factors very carefully, since their large number complicates the determination of the relationship between the indicator and the factors, and wrongful elimination of some factors precludes the adequacy of the model with empirical data. Thus, when building a regression model, there are complications in the selection of factors.

4. A condition for the proper application of regression and correlation analysis in studying the relationship between economic 
phenomena is the normal distribution of the population, which is observed only when this relationship is affected by many random, independent or weakly dependent factors that have a predominant influence on the end result. At the same time, the economic population with a normal distribution law even for one factor is rare, and in case of compatibility of factors is almost next to none. In addition, the method of least squares cannot be applied when the factors are functionally interdependent. Therefore, regression models cannot always be used because of the violation of normal distribution of socio-economic population phenomena and multicollinearity.

5. It is only possible to build a regression model to study the effect of factors on economic performance if the values of the factors are not random variables. At the same time, due to economic activity, the vast majority of factors involved in building the model are affected by a large number of other random factors. As a result of the random nature of the factors, it is impossible to determine the probability of the received forecasting results. Therefore, in many cases the regression model cannot be used because the factors are random variables, or complex formulas need to be used to transform them, basing on the method of instrumental variables.

6. After building the model and establishing its compliance with the statistical data, it is essential to check that the preconditions for its construction are fulfilled.

Thereby, the practical use of correlation and regression analysis to study the impact of factors on economic performance leads to some complications, and in many cases it cannot be used at all. That is why the method of statistical equations of dependencies, proposed by professor O. Kulynych, is used to study the relationship between the factors and economic performance.

Equation of dependencies ${ }^{28}$ is a statistical method of analysing the causal links between economic phenomena and processes. Its

${ }^{28}$ Kuliavets V. O. (2014), Prohnozuvannia rozvytku enerhorynku rehionu: Navchalnyi posibnyk [Forecasting the development of the region's energy market: A textbook]. Zhytomyr: ZhVI DUT (in Ukrainian), p. 181 
application is based on calculating the comparison coefficients, which are determined as the ratio of individual values of the same feature to its minimum or maximum level, depending on the nature of the change of the feature. In this manner, when the values of the feature increase, the comparison coefficients are calculated from the minimum level, and when they decrease - from the maximum level. Hence the comparison coefficients show the degree of change (increase or decrease) of the value of the feature to the accepted comparison base. The parameters of the dependence equation are calculated on the basis of the comparison coefficients of the indicator or factor. The parameters of the equation allow taking into account the impact of the cumulative effect of all factors on the indicator.

Applying equations of dependencies to assess the relationship of socio-economic phenomena allows to ${ }^{29}$ :

- calculate theoretical values of the indicator;

- determine the amount of the change in factors when changing the indicator by one or another given value;

- determine the size and level of change of an indicator when one or more factors that form the normative, planned or forecasted value of the indicator change;

- calculate the normative levels of factors that form the planned, regulatory or forecasted value of the indicator;

- determine the intensity of the factors usage to achieve the average value of the indicator by comparing the calculated optimal levels of factors with their actual average values;

- take into account not only the impact of one factor on the indicator, but also the combined effect of many factors;

- build a graph of the dependence under study.

The calculations of the parameters of the dependencies equations are performed in form of a table and the calculations show the following advantages comparing with the regression analysis ${ }^{30}$ :

29 Kuliavets V. O. (2014), Prohnozuvannia rozvytku enerhorynku rehionu: Navchalnyi posibnyk [Forecasting the development of the region's energy market: A textbook]. Zhytomyr: ZhVI DUT (in Ukrainian), p. 182 
- the initial term of the dependency equation makes real economic sense because it is the minimum or maximum value of the indicator;

- the values of the parameters and their indexes for both onefactor and multi-factor equations are the same;

- the interdependence between two or more factors appears only in calculating the dependence coefficients (impact quotient) that characterise their effect on the indicator;

- the sum of the linear deviations (not their squares) of the theoretical values of the indicator from their actual values should be minimal;

- when adding (removing) the factors included in the model, the parameters of the equation of dependencies and their indexes do not change and characterise the influence of this factor on the indicator;

- the use of statistical equations of dependencies provides the opportunity to receive a direct characteristic of the change of the indicator when changing the factor by one or at any given value.

The use of statistical equations of dependencies to analyse the interconnections between socio-economic phenomena requires ${ }^{31}$ :

- quality analysis of the factors under study and an indicator that implies the existence of logical dependence between them, as well as the use of direct features that allow performing regulatory calculations;

- homogeneity of the phenomenon under study - excluding from the calculations the values of the feature (minimum or maximum), which significantly differ (two or three times) from the amount following the minimum or the one preceding the maximum amount respectively;

${ }^{30}$ Kulynych O.I. (1998), Ekonometriia: Navchalnyi posibnyk [Econometrics: A Textbook]. Khmelnytskyi: Podillia (in Ukrainian), p. 23

31 Kuliavets V. O. (2014), Prohnozuvannia rozvytku enerhorynku rehionu: Navchalnyi posibnyk [Forecasting the development of the region's energy market: A textbook]. Zhytomyr: ZhVI DUT (in Ukrainian), p. 183 
- assessment of the connection stability between the phenomena, which are established, as the dependence under study nears to a specific type of equation, expressed by the corresponding connection formula.

Generally, several statistical equations of dependency are preselected and built, using the best in future. When choosing the best of the previously built statistical equations of dependencies the following criteria are used ${ }^{32}$ :

- comparison of graphical representation of empirical and theoretical lines of values of the economic indicator;

- comparison of the linear sum of deviations between the empirical and theoretical values of the economic indicator by the formula

$$
\sum_{i=1}^{n} e(t)=\sum_{i=1}^{n}\left|y_{i}-y_{i}^{*}\right| \rightarrow \min ;
$$

- comparison of the values of connection stability coefficients;

- comparison of the values of correlation indices.

In order to forecast the level of $Y_{\mathrm{n}}$ indicator a dependency is used if its empirical values:

increases

$$
Y_{n}=Y_{\min }\left(1+B D_{x s}\right)
$$

decreases

$$
Y_{n}=Y_{\max }\left(1-B D_{x s}\right)
$$

where $D_{\mathrm{xs}}$ is a sign of deviation from the unit of set values of factors, which is calculated by the formula

${ }^{32}$ Kuliavets V. O. (2014), Prohnozuvannia rozvytku enerhorynku rehionu: Navchalnyi posibnyk [Forecasting the development of the region's energy market: A textbook]. Zhytomyr: ZhVI DUT (in Ukrainian), p. 192 


$$
D_{x s}=\sum_{\mathrm{i}=1}^{m} d_{x s \mathrm{i}}
$$

$m-$ a number of factors.

The sign of deviation from the unit of set value of this factor is determined by the correlation if its empirical data:

increases

$$
d_{x s}=\frac{x_{s}}{x_{\min }}-1
$$

decreases

$$
d_{x s}=1-\frac{x_{s}}{x_{\max }}
$$

where $x_{s}$ is a set value of the factor.

The inverted task to the one considered is of particular interest for economic agents, namely: determining the factors and their change at a given level of an economic indicator or when changing it by a given value. This problem cannot be solved by the method of correlation-regression analysis, and solving it by the method of statistical equations of dependencies the information shall be used obtained by determining:

- the difference between the unit of the comparison coefficient of a given level of the indicator with its initial value in the dependence equation;

- the amount of deviation of the comparison coefficients of the factor features from the unit by dividing the obtained difference by the dependency parameters of the individual factors;

- the necessary levels of factors that are calculated by adding (subtracting) the unit to (from) the amount of the deviation of comparison coefficients of the factor, if its value increases (decreases), 
with the subsequent multiplication of the obtained result by the minimum (maximum) empirical value of the factor.

The aforementioned argumentation leads to the conclusion that it is appropriate to use the method of statistical equations of dependencies for researching and forecasting social and economic development of Ukraine by the parameters provided in table 1 . Statistical equations of dependencies allow to reasonably determine the economic and social development growth rates for future periods, calculate their forecasted levels, estimate the degree of influence of individual factors on the effective feature, as well as analyse the intensity of the factors usage for dynamic shaping of the economic phenomena development ${ }^{33}$.

\section{CONCLUSIONS}

The use of mathematical modelling in economics is an effective tool for optimising and improving the efficiency of managerial decision-making regarding the sectors of economic and social policy of the state, as well as for economically feasible planning of public expenditures. Consequently, the research related to building mathematical models of socio-economic development needs a more detailed study.

According to the results of the analysis of methodological approaches of economic and mathematical modelling, it is proved that the method of statistical equations of dependencies is the optimal method for assessing and forecasting indicators of economic and social development of Ukraine. Against this background, it makes sense using this method for studying the relationship between economic and social development and for mid-term forecasting of indicators related to the implementation of the social function by the state (particularly GDP, social standards, indicators of budget expenditures).

${ }^{33}$ Kulynych O. I. (2017), Pobudova funktsionalnykh modelei ekonomichnykh yavyshch metodom statystychnykh rivnian zalezhnostei [Constructing Functional Models of Economic Phenomena by the Method of Statistical Equations of Dependences] Statistics of Ukraine, no. 3, pp. 73-78 
The author gratefully acknowledges by Troshchinsky V. P., Kupriychuk V. M., Valinkevich N. V., Kulyavets V. A., Ventsel N. V. for helpful discussions, advice and support in performing research.

\section{SUMMARY}

The article deals the issues of using economic and mathematical modeling to improve the quality of management and the wellgrounded determination of state social costs. One of the main tasks of public authorities is to optimally determine the amount of social expenditures based on available resources. Methods of economic and mathematical modeling should be used to solve this problem. Currently, the use of mathematical models for managerial decision making in the field of social and economic development of the state is not very common and this tool is not given due attention. The issue of creating mathematical models of social and economic development of society needs more detailed study. The study considers some features of the correlation-regression method, the principal component method and the method of statistical dependence equations. It is argued that the most optimal method for studying the relationship between economic and social development and forecasting indicators related to the implementation of the social function of the state is the method of statistical equations of dependencies.

\section{REFERENCES}

1. Financial and economic analysis office in the VRU (2019). Analiz diialnosti fondu sotsialnoho strakhuvannia. [Analysis of social insurance fund activity]. Retrieved from: https://feao.org.ua/wpcontent/uploads/2019/04/2019-04-17-fss.pdf (accessed 02 November 2019)

2. Kharazishvili Yu. M., Liubich O. O. (2006) Systemne modeliuvannia sotsialno-ekonomichnoho rozvytku Ukrainy [System modeling of social and economic development of Ukraine]. Banking magazine, no. 3, pp. 46-65

3. Kuliavets V. O. (2009), Prohnozuvannia sotsialnoekonomichnykh protsesiv: Navchalnyi posibnyk dlia studentiv 
ekonomichnykh spetsialnostei vyshchykh navchalnykh zakladiv [Predicting socio-economic processes: A textbook for students of economic specialties of higher education.]. Kyiv: Kondor (in Ukrainian)

4. Kuliavets V. O. (2014), Prohnozuvannia rozvytku enerhorynku rehionu: Navchalnyi posibnyk [Forecasting the development of the region's energy market: A textbook]. Zhytomyr: ZhVI DUT (in Ukrainian)

5. Kulynych O.I. (1998), Ekonometriia: Navchalnyi posibnyk [Econometrics: A Textbook]. Khmelnytskyi: Podillia (in Ukrainian)

6. Kulinich E.I. (2001), Ekonometriya [Econometrics]. Moskva: Finansy i statistika (in Russian)

7. Kulynych O. I. (2003), Ekonometriia: Navchalnyi posibnyk. [Econometrics: A Textbook]. Khmelnytskyi: Podillia (in Ukrainian)

8. Kulynych O. I. (2017), Pobudova funktsionalnykh modelei ekonomichnykh yavyshch metodom statystychnykh rivnian zalezhnostei [Constructing Functional Models of Economic Phenomena by the Method of Statistical Equations of Dependences] Statistics of Ukraine, no. 3, pp. 73-78

9. Lopatnikov L. I. (2003) Ekonomiko-matematicheskiy slovar': Slovar' sovremennoy ekonomicheskoy nauki [Economics and Mathematics Dictionary: Dictionary of Modern Economics]. Moscow: Delo (in Russian)

10. Nakonechnyi S. I., Tereshchenko T. O., Romaniuk T. P. (2000), Ekonometriia: Pidruchnyk [Econometrics: A textbook]. Kyiv: KNEU (in Ukrainian)

11. OECD (2019), Social spending (indicator). doi: 10.1787/7497563b-en. Retrieved from: https://stats.oecd.org/ Index.aspx?datasetcode=SOCX_AGG\# (Accessed on 02 November 2019)

12. OECD. Stat (2019). Retrieved from: https://stats.oecd.org/ Index.aspx?datasetcode=SOCX_AGG\# (Accessed on 02 November 2019) 
13. Opria A. T. (2017), Statystyka. Navchalnyi posibnyk [Statistics. A textbook]. Kyiv: Tsentr uchbovoi literatury (in Ukrainian)

14. Pension Fund of Ukraine (2019). Zvit pro robotu ta vykonannia biudzhetu pensiinoho fondu Ukrainy u 2018 rotsi [Report on the operation and implementation of the budget of the Pension Fund of Ukraine in 2018]. Retrieved from: https://www.pfu.gov.ua/ content/uploads/2019/03/Zvit_2018_21_03_2019.pdf

(accessed 02 November 2019).

15. Pihul N., Liuta O., Boiko A. (2015), Finansove zabezpechennia sotsialnoi sfery v Ukraini [Financial support of social sphere in Ukraine]. Herald of the National Bank of Ukraine, no. 1 (227), pp. 30-35

16. Shyian A. A. (2008), Matematychna model vplyvu suspilnykh instytutiv na efektyvnist ekonomiky Ukrainy [Mathematical model of influence of public institutes on efficiency of economy of Ukraine]. Visnyk of Vinnytsia Polytechnical Institute, no. 2, pp. 19-23

17. State Statistics Service of Ukraine. Retrieved from: http://www.ukrstat.gov.ua/

18. State Treasury Service of Ukraine (2019). Richnyi zvit pro vykonannia Derzhavnoho biudzhetu Ukrainy za 2018 rik [Annual report on execution of the State Budget of Ukraine for 2018]. Retrieved from: https://www.treasury.gov.ua/ua/file-storage/richnijzvit-pro-vikonannya-derzhavnogo-byudzhetu-ukrayini-za-2018-rik (accessed 02 November 2019)

19. State Treasury Service of Ukraine. Retrieved from: https:// www.treasury.gov.ua/ua/file-storage/vikonannya-derzhavnogo-byudzh etu

20. Ventsel V. (2018), Biudzhetna polityka yak osnovnyi instrument zabezpechennia derzhavoiu sotsialnoi funktsii [Budget policy as the main instrument for providing state social function]. Public Administration: Theory and Practice (electronic journal), no. 2, pp. 24-35. Retrieved from: http://www.e-patp.academy.gov.ua/pages/ 
dop/23/files/6bc2f41d-f34f-4ee3-8d43-dcbd1d0a6204.pdf （accessed 02 November 2019)

21. Vlasiuk O. S. (2011) Ekonomiko-matematychne modeliuvannia protsesiv sotsialno-ekonomichnoho rozvytku Ukrainy [Economic and mathematical modeling of the processes of social and economic development of Ukraine]. Kyiv: SESI "Academy of Financial Management" (in Ukrainian).

\section{Information about the author: \\ Viktor Ventsel,}

$\mathrm{PhD}$ of Economic Sciences,

Doctoral Student at the Department

of Social and Humanitarian Policy,

National Academy of Public Administration under the President of Ukraine

20, Ezhena Potie str., Kyiv, 02000, Ukraine

ORCID ID: 0000-0002-1902-6126 
DOI https://doi.org/10.36059/978-966-397-162-9/160-187

\section{INSTITUTIONAL NATURE OF THE TAXES AND THE FISCAL CONVERGENCE, AS A PHILOSOPHY OF THE TAX SYSTEM PUBLIC ADMINISTRATION}

\section{Krushelnytska Taisiia}

\section{INTRODUCTION}

The evolution of taxes and their transformation into the main source of state revenue both creates an opportunity and poses the task of studying their nature, economic meaning and principles of application in dynamics and in accordance with the development of society.

Integration processes caused by the globalization of the world economy at the end of the XX century - beginning of the XXI century, became a civilizational source of a significant change in the theoretical views on the nature of taxes, illuminating them in a new light. At the same time, throughout the twentieth century (up until Ukraine gained independence in 1992) the tax system in Ukraine was in decline in both theoretical and practical aspects. In the Soviet times, the economic laws were violated, the corresponding state tax institutions were destroyed, which became a difficult theoretical and institutional legacy. In a significant respect, this has become a major factor in slowing down the development of the tax system's public administration in Ukraine today. Therefore, the theoretical redefinition of the taxes' meaning in institutional and status respect within the contemporary public management is an important scientific challenge. It has become especially relevant in the context of the economic and political crisis in Ukraine.

The theory of taxes arose and developed simultaneously with the taxes themselves. The concept of "tax", which has its roots in the depths of centuries, arose even before commodity-money relations, evolved along with the development of the state and the formation of the economically administrative architecture of society. Although the 
theory of taxes emerges in the works of ancient philosophers, for example, Plato ${ }^{1}$, a modern scientific understanding of the nature of taxes is based on classical theoretical views, formed around the $18^{\text {th }}$ century. In addition, as early as at the beginning of the XVIII century both the practice of applying taxes and also the theoretical understanding of their nature and role as an effective instrument of public administration were already systematically represented.

Theoretical understanding of the concept of tax has evolved over the following centuries. Nowadays it lies at the basis of the modern paradigm of tax theory and public administration of the tax system. The honorary creators of the doctrine of taxes of the past (M. Nitti, V. Petty, F. Panteleoni etc.) and contemporaries (P. Samuelson, E. Seligman, M. Friedman and many others) established many scientific schools, that considered the category of taxes from their own angle. However, all of them agree that the nature of taxes is complex and multifaceted and is defin by the laws of reproduction. Their views touched upon philosophical, economic, social, and legal aspects of taxes. The modern theoretical, scientific, practical and legal perception of the diverse nature of the concept of "tax" varies from the philosophical concept to an objective economic category, to institutional norms of public administration and public relations, depending on taxpayers and the state. At the same time, one should take into account the fundamental dualism of the nature of taxes: they act both as a method and as a source of state revenue.

In the course of the study of the nature and modern content of the category "tax", we tried to follow the logic of gradual and consistent penetration into the essence of the phenomena and processes that took place during the formation of the statehood.

Under the influence of the evolution of public administration, the role of taxes and theoretical ideas about them changed. Today, according to the concept of new public management, taxes are

${ }^{1}$ Платон Государство. пер. с древнегреческ. - Собр. соч. в 4-х т. М. : Мысль, 1994. - Т. 3. - С. 57-64. (Серия «Философское наследие»). 
becoming an institutional norm. They have transformed from a tool of pure coercion into a tool of public welfare. The study of this transformation and the definition of the new role of taxes in public administration and in the real sector of economy make the relevance of this article.

The purpose of this article is to justify the institutional nature of the tax in the context of the concept of a new public administration and the definition of fiscal convergence as a philosophy of modern tax relations.

The role of taxes and theoretical ideas about them have been changing simultaneously with the evolution of public administration. Nowadays, according to the concept of a new public management, taxes acquire the status of an institutional norm. They transformed from an instrument of pure coercion into an important element of social welfare. The study of this transformation, the definition of the new role of taxes in public administration, and in the real sector of the economy determine the relevance of this article.

The aim of this study is to analyze the institutional nature of tax in the context of new concept of public administration, as well as definition of fiscal convergence as a philosophy of modern tax relations.

\section{Evolution of the institutional content of taxes}

The study of the history of civilization testifies that taxes are rather a late form of government revenue. First of all, they were not of a regular or permanent nature, they were levied occasionally in empirically determined amounts. The necessity to pay taxes led to the discontent among the population because it was widely thought that taxes contradicted the principle of the inviolability of private property. People believed that the taxes could be collected in exceptional cases as a temporary source of public revenue in a critical situation for the ruler or the state.

Nowadays taxes are associated with the withdrawal of individual revenues, their accumulation in the national fund, and socio-economic and administrative and political relations. As early 
as in the first half of the $17^{\text {th }}$ century the English Parliament did not recognize permanent taxes on public needs, but over time, due to the need to cover public needs, the taxes have evolved from a temporary to a permanent source of public revenue. There are no earlier periods.

Gradually, taxes become a common source of replenishment of state budgets. However, the taxes became especially popular with the advent of the developed market economy. It is in those conditions, that the tax system, typical for any contemporary state was created. Also during that period the taxes became the main source of the state revenue and were transformed into the most vulnerable and contradictory element of the economic, fiscal and legal relations between the state and taxpayers, requiring constantly growing efforts to control and manage them.

The constant quest for the optimal variants and forms of taxes and mechanisms of their collection illustrates the transformation from the origin to become a value. Thus, the evolution of the perception of taxes' meaning fluctuated between conflicting statements: from the well-known view of tax as a permitted form of robbery (according to F. Aquinas ${ }^{2}$, to their inevitability as death (according to B. Franklin ${ }^{3}$. S. Montesquieu, in turn, famously stated that nothing requires so much wisdom and intelligence as the definition, which part of earnings should be taken away from the citizens (taxes) and which should be left ${ }^{4}$. It is to be stressed, that the taxes emerged as a necessary link in economic relations in society simultaneously with the birth of the State. As K. Marx put it, taxes remain unquestionably "... the economically expressed existence of the state"

2 Словник економічної афористики / уклад.: А. Г. Загородній, Г. Л. Вознюк. - Львів: Видавництво Львівської політехніки, 2013. С. 257.

3 Якушик І. Д. Податки в країнах світу. Довідник. К.: Леся, 2004. 479 с.

4 Монтексьє Ш. Избранные произведения в 2-томах; под. ред. М. П. Баскина. М. : гос. Изд-во Полиграфической литературы, 1955. С. 31.

${ }^{5}$ Маркс К., Енгельс Ф. - Соч. - 1987. 2 изд. Т. 4. С. 308. 
Between its emergence in the ancient world and the classical concept in the XIX century, the taxes were predominantly understood as a nonequivalent payment to the state. However, since the middle of the XIX century, the taxes started being understood as a public payment for the execution of the state's functions. Such a transition became possible only through the transformation of the social system, creation of a system of socially democratic values, the emergence of the perception of the state as being responsible before the citizens. In other words, the evolution of the understanding of taxes in the theory of public administration was caused by the practical need of society to harmonize the relations between the state and its citizens and consider both elements to be part of the dynamic system, sensitive to the external changes.

Smith was among the first theorists to contribute to the development of the theoretical meaning of the concept of "tax". In The Wealth of Nations (1770) he noted that tax is a burden imposed by the State in the form of a law that stipulates its amount and procedure of payment ${ }^{6}$. Later, taxes began to be considered as a redistribution of the public national product. This view was justified by the fact that the amount of taxes depends on the conditions of the creation of the total income of society. Hence, the nature of taxes should not be limited only to the formation of budgetary resources, so the logical chain of tax participation in public reproduction should be extended. Smith emphasized that taxes are necessary to satisfy such public goods as defense, ensuring the safety of citizens and their property, education and only in isolated cases - to ensure the implementation of contracts ${ }^{7}$. The theory of social reproduction, which is based on the doctrine of K. Marx ${ }^{8}$, considered taxes exclusively as a part of the value of goods, which needs to be nullified for the reproduction of society.

6 Смит А. Исследование о природе и причинах богатства народов. Антология экономической классики в 2-х т. М. : Эконов, 1993. Т. 1.С. 37-39.

${ }^{7}$ Ibid. C. 37.

${ }^{8}$ Маркс К., Енгельс Ф. - Соч. - 1987. 2 изд. Т. 4. С. 308. 
Stiglitz believed that the taxes allow the state to perform its functions, forming hereby an individual price of tax as a tax payment. The individual is forc to make it in the form of tax payments? ${ }^{9}$.

V. Andrushchenko believes that the complexity of the scientific understanding of the nature of the tax is a consequence of the multidimensionality of the phenomenon itself, which reflects the mixture of economic, social, political, regulatory, moral, ethical, social and psychological properties ${ }^{10}$. In the XIX century, M. Alekseenko noted that, on the one hand, the tax is one of the elements of distribution and pricing policy, and on the other hand - it is one of the functions of the state ${ }^{11}$. If we reflect on this thesis, it becomes evident, that taxes provide the state with the opportunity to perform its inherent functions and their justice, or, conversely, injustice depends on the degree of development of democratic forms in the state and tax culture of citizens.

However, the definition of the of taxes as the price of state services implies, in our view, that the equivalent, reverse nature of tax relations is not a single act of tax payment (and receipt of benefits), but a regular repeated operation, carried out at the macroeconomic level. The state in this sense acts as a personified economic entity.

Therefore, it is quite a common view that taxes are a payment for indivisible public services provided by the state. The discussion around this definition began at the end of the 19th - beginning of the 20th centuries and was developed by D. Mill, F. Nitti, P. Samuelson, Jean S. de Sismondi and other prominent scientists. Thus, Jean

9 Stieglitz Joseph E. Economics of the public sector. New York / London : W. W. Norton\& company. 2000. URL: http://www.ebay.com/ctg/economics-publicsector-joseph-e-stiglitz-2000-hardcover-subsequent-edition-/118991.

10 Андрущенко В. Л. Морально-етичні імперативи податків та оподаткування (західна традиція). Монографія. К.: Алерта. 2013. С. 32-33.

11 Алексеенко М. М. Взгляд на развитие учения о налоге у экономистов А. Смита, Ж.-Б. Сея, Риккардо, Сисмонди и Д. Миля. Москва : Издательская груnпа URSS, Изд. 2. Серия: Классика политэкономической мысли. 2012. С. 65. 
Simonde noted that the tax is the value paid by a citizen for the enjoyment with public order, justice, personal liberty and property rights ${ }^{12}$. The author considered that taxes cover the annual expenses of the State, and each taxpayer thus contributes to the total expenses incurred for him and other citizens ${ }^{13}$.

The German financial expert Neumann, on the other hand, refers to taxes as "... payments, introduced to generate income for the State and communities since the latter are not rewarded for the special services..." 14 . In other words, scientists have not reached a consensus on the essence of the tax, even when we speak about its narrow definition through socially relevant services.

D.Ricardo considered taxed from another perspective: he believed that taxes should be used only for fiscal purposes because they hinder the process of formation and accumulation of capital, and therefore the best tax is the least tax ${ }^{15}$.

Representatives of the German school (L. Stein and W. Sombart) considered taxes from a different angle: according to their theory, taxes represent the productive consumption of capital ${ }^{16}$. Thus, in particular, L. Stein considered the tax as a production expense - each tax is included in the costs of production of the goods and thus transferred to all consumers, this tax is returned to the citizens in the form of public services and increasing labor productivity ${ }^{17}$. V.Pushkareva also shares the views of the classical representatives of

12 Сисмонди Симонд де Жан-Шарль-Леонард. Новые начала политической экономии или о богатстве в его отношении к народонаселению. Москва. Госиздат, 1937. 386 с.

13 Ibid.

14 Ярошенко Ф. О., Павленко В. В., Павленко В. П. Історія податків та оподаткування в Україні. Навч. посіб. за заг. ред. А. М. Подоляки. К.: ДП «Вид. дім «Персонал». 2012. С. 8.

15 Рикардо Д. Начала политической экономии и налогового обложения. Антология экономической классики в 2-х т. М. : Эконом, 1993. Т. 1. С. 397.

16 Суторміна В. М., Федосов В. М., Андрущенко В. Л. Держава податки - бізнес (зі світового досвіду фіскального регулювання ринкової економіки). Монографія. К. : Либідь, 1992. С. 11.

${ }^{17}$ Ibid 
the economic theory ${ }^{18}$. She considers the economic nature of the tax from the perspective of the theory of price and the theory of supply in determining the source of taxation (capital, income) and the impact of the tax on private firms and the economy in general. Therefore, she believes that the economic nature of the tax resides in the sphere of production and distribution ${ }^{19}$.

At the beginning of the XIX century such scientists as I. Kulisher, I. Ozerov, V. Tverdokhlebov, M. Turgenev) considered taxes as an instrument of economic and social reforms. In their view, it is used by the state for redistribution of property, support of certain and development of other forms of management as means to achieve some social or governmental goal ${ }^{20}$. We consider the latter statement to be true, but not sufficient to highlight the multidimensional nature of taxes.

A separate group of scientists considers the tax as a set of relations between the state and taxpayers (Y. Lytvynenko, E. Milyavska, V. Oparin etc.). Thus, for example, according to the definition of J. Litvinenko, taxes are an obligation, a compulsory payment, which exists in the economic basis and within economic relations $^{21}$.

V. Oparin believes that "... the economic content of taxes reflects the financial relations between the state and taxpayers to create a national centralized fund of funds necessary for the state to perform its functions" $"$. B. Vishnevsky and A. Vetkin defined taxes as “... a

${ }^{18}$ Пушкарева В. М. История финансовой мысли и политики налогов. М. : Финансы и статистика, 2001. С. 208.

19 Ibid.

20 Кулишер И. М. Очерки финансовой науки. Вып. 1. Петроград: Книгоиздительство «Наука и школа». 1919. С. 66.

21 Літвіненко Я. В. Податкова політика. Навч. посіб. К.: МАУП, 2003. C. $17-18$.

Опарін В. Фінансова система України (теоретико-методологічні аспекти). Монографія. К. : КНЕУ. 2005. С. 136. 
specific product of the development of public relations",23. It should be noted, that the Western scientists usually do not analyze the "tax relations" - this approach is most typical in the scientific Soviet and post-Soviet period and space. Of course, we do not deny the right to existence of the concept of "tax relations", especially given the heterogeneity of the nature of taxes, but we consider the tax system, the determining element of which are taxes, as a set of economic and legal relations.

With the development of the state and social relations, scientific views on the nature and essence of taxes narrowed down to the vision of their mandatory payment to the budget. For example, O.Vasilik defines taxes as mandatory payments, which are taken by the state from the income of legal entities or individuals to the corresponding budget to finance the state's expenditures, with the process being regulated by the constitution and other legislative $\operatorname{acts}^{24}$. At the same time, he emphasizes that taxes can be considered as the method of equalization of income of legal entities and individuals and serve as feedback with the taxpayers via the financing of relevant expenses. The latter statement, in our opinion, is true only in an abstract sense.

Discussion of theoretical views on the nature of the tax does not stop today. However, as a result of the evolution of tax theory and the gradual transformation of the role of the state in the regulation of the economy, the tax obtains several specific features. Such traits as unilateralism of the tax, coercive nature, coverage of costs for the performance of functions and the like are reflected in the most of the thematic scientific publications of the late XIX, early XX century. These features in the definitions of tax in scientific developments have become permanent and mandatory. In the table below we present a

23 Налогообложение: теории, проблемы, решения. Монографія / В. П. Вишневский, А. С. Веткин, Е. Н. Вишневская и др.; под. общ. ред. В. П. Вишневского. Донецк: ДонНТУ, ИЭП НАН Украины, 2006. С. 62.

24 Василик О. Д. Податкова система України. Навч. посіб. К. : Поліграфкнига, 2004. С. 43. 
snapshot of the scientific views on the concept of taxes, as a consistent and compulsory payment, ranging from a somewhat sharp, in our opinion, the vision of E. Seligman, R. Strum ${ }^{25}$ and ending with the definition of V. Panskov ${ }^{26}$. The latter, which has become quite widespread, considers the taxes as unrequited payment, which does not presuppose any response (i.e. fulfillment of specific functions) from the state.

Global processes (international economic integration, in particular) contributed to the emergence of conceptually new views on taxes, which came into contradiction with the theory of collective needs, formulated as early as the end of the XIX century - beginning of the early 20th century (Table 1).

Thus, F. Nitti believed that the tax is a certain amount of wealth citizens give to the state and local authorities to meet the collective needs ${ }^{27}$. A. Bukovetsky, A. Ganzel, and others were among the Russian scientists adhering to this theory ${ }^{28}$. It should be noted, that it is the theory of welfare, which today is dominant in the theoretical understanding of the taxes, has radically changed the views of scientists. Beginning from the end of the XX century, the Western theoretical tradition inextricably linked taxes to the concepts of the public good, public choice, reorientation to the interests of the individual, while also studying external and internal effects of public administration of the tax system. As a result, there is a need for an explanation of the causes, consequences and methods of elimination of such phenomenon as tax evasion.

${ }^{25}$ Селигман Э., Стурм Р. Этюды по теории обложения: пер. студентов В. Гефдинга и Б. Никольского. Под. ред. и с предисловием проф. М. И. Фридмана. СПб. 1908. 231 с.

26 Павлюченков С.А. Орден меченосцев. Партия и власть после революции. 1917-1929. Монография. Собрание, 2008. 464 с.

${ }^{27}$ Нитти Ф. Основны начала финансовой науки: Перевод съ итальянского И. Шрейдера ; под редакцией и съ дополнениями А. Свирщевского. М. : Издание М. ис, Сабашниковыхъ, 1904. 623 с.

${ }^{28}$ Буковецкий А. И., Гензель П. П., Кулишер И. М., Твердохлебов В. Н. Налоги в иностранных государствах. М. Финансовое издательство НКФ СССР. 1926. 312 c. 
Definition of tax compulsory and mandatory payment

\begin{tabular}{|l|l|}
\hline \multicolumn{1}{|c|}{ Source } & \multicolumn{1}{c|}{ Definition of tax } \\
\hline E. Seligman, Strum $^{29}$ & $\begin{array}{l}\text { Mandatory payment, gathered by state from } \\
\text { individuals for covering expenses, related to } \\
\text { the nation-wide needs. The specific benefits } \\
\text { of taxpayers are not presupposed. }\end{array}$ \\
\hline A.A. Isayev & $\begin{array}{l}\text { Mandatory cash payments by private } \\
\text { households that cover the total costs of the } \\
\text { state and local government units }\end{array}$ \\
\hline $\begin{array}{l}\text { B.B. Buryakovski, } \\
\text { S. Kalambet }{ }^{31}\end{array}$ & $\begin{array}{l}\text { The mandatory payment established by the } \\
\text { supreme body of state legislative power, } \\
\text { which individuals and legal entities pay to } \\
\text { the budget in the amounts and within the } \\
\text { time limits prescribed by law. }\end{array}$ \\
\hline B.Г. Panskiv ${ }^{32}$ & $\begin{array}{l}\text { Mandatory, individually irrevocable, } \\
\text { relatively regular and legislatively payment, } \\
\text { established by the state and paid by } \\
\text { organizations and individuals to financially } \\
\text { support the activities of the state and } \\
\text { municipalities. }\end{array}$ \\
\hline
\end{tabular}

In such a way, the evolution of the scientific understanding of the taxes had several stages of development. Below we will list seven stages identified by E. Seligman as early as in 1998 (we present them with the generalization of N. Goritskaja):

${ }^{29}$ Селигман Э., Стурм Р. Этюды по теории обложения: пер. студентов В. Гефдинга и Б. Никольского. Под. ред. и с предисловием проф. М. И. Фридмана. СПб. 1908. 231с.

${ }^{30}$ Исаев А. А. Очерк теории и политики налогов. М. : ООО «ЮрИнформ Пресс». 2004. 270 c.

31 Буряковский В. В., Кармазин В. А., Каламбет С. В. Налоги. Учебное пособие. Днепропетровск : Пороги, 1998. 611 с.

32 Пансков В. Г. Российские налоги. Нужна научная основа. Российский экономический журнал. 1993. № 3. С. 12. 
- at the very first stage, the idea of the donation was dominant (in the Middle Ages, it was considered, that the tax is an individual gift to the government);

- at the second, the government itself has humbly asked the people for support;

- at the third stage it was believed that the citizens assisted the state in fulfilling its functions;

- at the fourth stage the idea emerged, that the individuals make a sacrifice in the interests of the state;

- at the fifth stage, the payer of taxes is thought to proceed from the sense of duty and responsibility;

- at the sixth stage it is believed, that the state coerces the individuals to pay taxes;

- at the last, seventh stage, the idea came up, that the state deducts a certain calculated amount from the salary of the citizens, independent from their approval ${ }^{33}$;

- we would add the eighth stage, where the tax is considered as a source for satisfying collective needs, so it combines both voluntary and forced characteristics.

By the end of the $20^{\text {th }}$ - beginning of the 21 st centuries, the development of tax theory reached a new stage. In other words, today we can talk about the ninth stage of evolution in the understanding of the nature of taxes, the main contributors to which are the supporters of institutionalism. Thus, the institutional theory defines the tax concerning the payer as (1) mandatory; (2) voluntary; (3) compulsory payment ${ }^{34}$. The behavior of taxpayers could be determined by three motivations, but the task of public administration is to determine the optimal ratio between them. In the majority of countries with developed economies and established democratic legal traditions, the second and third motivations

33 Горицкая Н. Подоходный налог с граждан: будущее в прошедшем. Налоговое право. № 5. 1999. С. 22.

34 Андрущенко В. Л. Морально-етичні імперативи податків та оподаткування (західна традиція). Монографія. К.: Алерта. 2013. 214 с. 
prevail, while in Ukraine and other CIS countries the first and third, respectively, are dominant. This trend can be explain by the fact, that the taxation and the public awareness of its necessity started being formed only in the $90 \mathrm{~s}$.

Nowadays, amid the intensification of globalization processes and associated international economic integration, we witness a formation of a motivational society with a focus on the needs of the individual. We should also add that the formation of the state tax policy is increasingly influenc by the factors of irresistible force: tax competition, the growth in prosperity in neighboring countries, the need to solve social problems, the desire to equalize the tax burden and the like. Therefore, the interpretation of the coercive nature of taxes is constantly subjected to scientific criticism, freeing up space for their voluntary and mandatory nature interpretations. Thus, Richard Musgrave proposed an alternative concept of voluntary fiscal exchange with the following scheme: taxes are paid in exchange for public and social benefits provided by the state ${ }^{35}$. Today, scientists (V. Vishnevsky, A. Vetkin, etc. ${ }^{36}$ ) increasingly propose to consider taxes as both voluntary payments (payment in exchange for public goods) and compulsory (payers give away part of their resources for external purposes).

We support the position of L. Andruschenko, who argues, that the willingness to pay taxes in society is the result of responsibility of citizens, supplemented by the corresponding law system, accepted by the power representatives ${ }^{37}$. We would also add that social benefits, created by the public power are another

35 Musgrave R. A. The Voluntary Exchange Theory of Public Economy. Quarterly Journal of Economics. 1939. Vol. 53. P. 213-237.

36 Вишневский В. П., Веткин А. С., Чекина В. Д., Виецкая О. В., Вишневская Е. Н. Формирование и реализация налоговой политики в сфере управления развитием промышленности. Монография. НАН Украины, Ин-т экономики пром-сти. Донецк, 2014. С. 60.

37 Андрущенко В. Л. Фінансова думка Заходу в XX столітті (Теоретична концептуалізація i наукова проблематика державних фінансів). - Львів : Каменяр, 2000. 303 с. 
important motivational force. This thesis once again proves that the tax in a democratic state of the XXI century governed by the rule of law can be considered neither a purely voluntary nor a purely mandatory payment.

However, the question about the voluntary or compulsory nature of taxation refers to all spheres of an individual's existence, that is, not only economic and political but also social, psychological, mental, etc. The taxpayer should understand and recognize the complex process of the redistribution of public goods, which is carried out through taxation. To a certain degree, this mechanism allows mitigating the unevenness of the material conditions of the existence of other individuals through equal access to the benefits of collective consumption and providing the opportunity to use the benefits of market or individual consumption.

However, for the majority of taxpayers, such philosophical reasoning about the benefits and taxes they receive is too onerous. Moreover, both the poor quality of public services and bureaucratization of tax institutions in Ukraine undermine the authority of the state itself, which makes it less likely, that the citizens will be motivated to pay taxes voluntarily. We would like to emphasize that it is the motivation of voluntary payment of taxes, as a socially conscious justification of the entire process of taxation that ensures the progressive development of society. The readiness of tax bearers to pay the taxes voluntarily is a phenomenon, which is very likely to occur in case of a long-term consistent formation of an appropriate outlook, strengthened by the real use of public goods. We call this a tax culture of citizens.

Tax culture is an element of long-term state tax policy. It results in the formation of a system of norms, rules of conduct, and worldviews that make tax evasion impossible. Its formation takes a long time and demands implementation of a multidimensional approach (nurturing, promotion, the introduction of regulatory incentives or restrictions, etc.). Still, it is possible to nurture the tax culture for a duration of hundred years and it will not take a leading position in the society as an institutional norm if the taxes are not 
materialized into the public good. This is especially noticeable in Ukraine, a country where there is a war, and citizens want the funds withdrawn from their salaries as taxes to be invested in defense, security, and development areas.

Summarizing, we can identify two leading approaches to the theoretical justification of the category "tax" in the history of science. The former is based on the recognition of the mandatory nature of taxes and was historically based on incentive and coercive methods of tax collection. Gradually the procedure of tax collection transformed from the tough measures to softer, more civilized forms. The latter, in turn, defined tax as a duty of citizens and relied on the voluntary nature of the tax. It can be considered a result of the evolution of a democratic society, the growth of the authority of the state and the increase in individual awareness of the necessity of paying the taxes.

Analysis of the concept of "tax", from its philosophical sources to the formation of legislative norms and the mechanism of practical implementation of taxation allows us to consider the theoretical essence of taxes through the prism of their institutional and status characteristics (See Fig. 1).

We believe that the tax should be seen as a unique institutional norm the nature of which is multifaceted and contradictory. At the same time, the institutional characteristic of the tax resides in its exclusive role in the process of influencing public production, and the distribution of public goods, which is carried out through taxation. It allows mitigating the unevenness of the material conditions of individual and social existence in a certain way.

In such a way, we define taxes as a heterogeneous, unique, institutional norm of public administration of voluntary and compulsory nature. It is calculated proceeding from the socioeconomic development of the country, is used in the process of redistribution of public goods, provides the formation of budget income and enables the reduction of inequality of social and material conditions. 


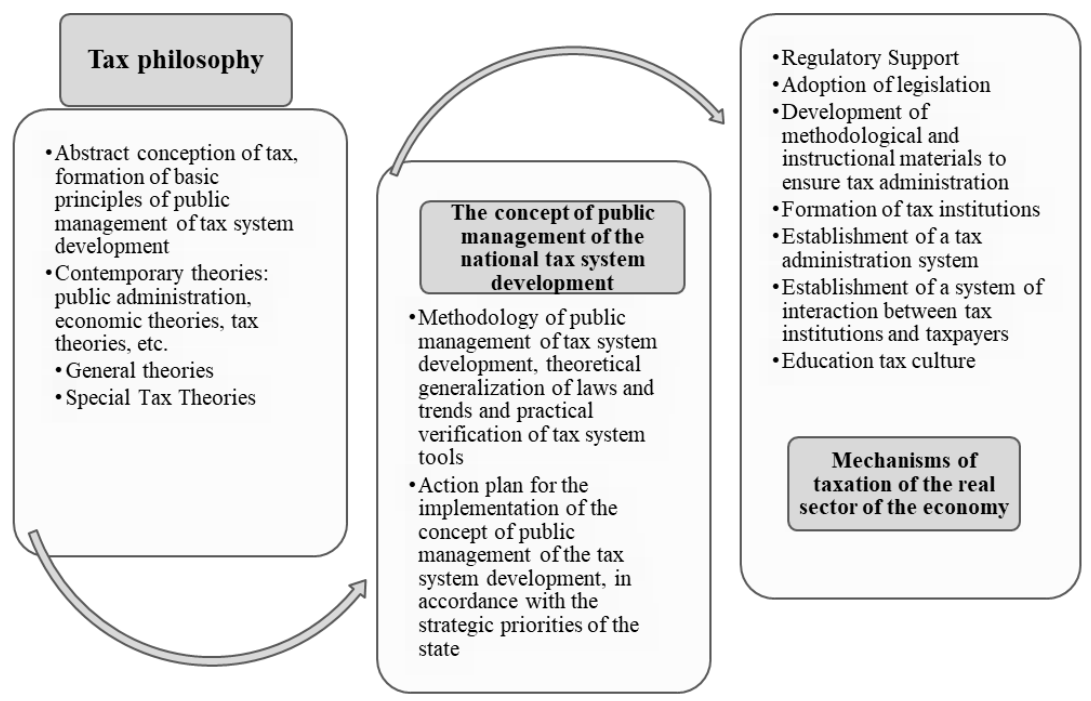

\section{Fig. 1. The logic of determining the essence of the category "tax"}

Institutional nature of the tax is manifested in its fullest form through the awareness of the role of public administration of the tax system, the use of state tax levers and regulation of tax relations.

\section{Fiscal convergence as a philosophy of public administration of tax systems}

When considered from the point of view of tax relations regulation in the country and abroad, the state management of the tax system in different countries gradually relies on conceptual approaches aimed at uniting the interests of all participants of the tax process: the state, taxpayers and tax bearers (individuals and legal entities). Considering, that it is necessary to take into account the individual needs and peculiarities inherent in the modern stage of civilization development, further unification of the interests of the participants of the tax process and their desire to balance the possible benefits and available resources becomes a natural and predictable phenomenon, which gradually turns into an intra-national fiscal convergence. 
Nowadays the fiscal convergence is considered merely in the international aspect, which is important, but not sufficient for building an effective tax system management in the conditions of Ukraine's integration into the world economic space. Contradictions, inaccuracies, the ambivalence of tax relations between the participants of the tax process (tax institutions and subjects of taxation), imperfections and high cost of administration, etc. make it impossible to infuse the national tax system into the international one harmoniously. Therefore, progress towards integration into the international tax system should start with national fiscal convergence.

In our view, the national public administration in the area of taxes should prioritize the following: consider the possibility of extrapolating the experience of the world's leading countries to building of Ukrainian tax policy, constructing mechanisms and tools of the tax system with attention to the harmonization of tax relations, based on the application of the philosophy of fiscal convergence. Such a need is aggravated by the following fact: amid Ukraine's integration into the world economic space, the issue of regulation of social and economic relations between the participants of the tax process (that is, between the state and society) remains a permanently unresolved issue in the process of building a harmonious tax system.

We believe that the philosophy of public administration of the tax system is based on overcoming the conflict between the perception of the opponents of tax relations (the state and taxpayers), the ratio of the level of public goods provided by the state and the level of the tax burden. It is because of the growing acuteness of this contradiction that the scientists believe that " $\ldots$ the ideal of the optimal taxation is unattainable because the formation of the national tax system is usually a result of the compromise of interests between political groups ${ }^{\prime 38}$. Perhaps, taking this into account,

38 Соколовська А. М. Податкова система України: теорія та практика становлення. Монографія. К. НДФІ, 2001. С. 7. 
A. Sokolovskaya suggests building tax relations within the "corridor", which was a consequence of "the compromise achieved between the interests of various political forces ..."39. We would add to this the following thesis: the compromise, mentioned above, should be reached between all participants of the tax process. The interests of all the groups should be taken into account, and it depends on the competence of public administration to set the boundaries to the said corridor and to coordinate the public and business interests. In support of this, I would like to quote Oleg Yuldashev: “... we enter a period of systemic development of a new type of dialogue between the authorities and entrepreneurs" $" 40$. This new type of dialogue can be implemented in the form of national fiscal convergence. It was written in 2006. Today, public-private partnerships and tax policy orientation towards a common interest compromise have become common practice ${ }^{41}$.

In the complex process of tax system management, the coordinating and controlling role is played by the state tax institutions, which are part of the tax system. Entrepreneurs and individuals are outside of the direct state administration, but they are subject to regulatory requirements and are a source of tax flow. So, in our opinion, they play an important role in the process of functioning not only the tax system but also the state as a whole. On the other hand, effective management of the taxation process is impossible without the influence of the state on the subjects of taxation (and we are having in mind not only administrative and regulatory levers here). As the world practice shows, today motivational and individual approaches to the formation of tax relations are becoming more relevant.

39 Ibid.

40 Юлдашев О. Ще раз про методологію удосконалення державного управління: може, востаннє? Юридичний журнал. 2005. № 9. C. 4. URL: http://www.justinian.com.ua/article.php?id=1894.

41 Крушельницька Т. А Теоретична сутність і практичне наповнення податкового потоку як об'єкту державного управління. Державне управління: удосконалення та розвиток: електронне наукове фахове видання. Київ. 2015. № 3. URL: http://www.dy.nayka.com.ua/. 
The state should ensure a maximum inflow of funds to the budget in the form of taxes to provide certain socially useful benefits to the population. Moreover, to ensure compensation for public costs (which is one of the primary interests of the state), tax rates are increasing, and the volume of socially useful goods are gradually decreasing. That is why, to encourage citizens to pay taxes voluntarily the public administration should develop and introduce a corresponding state program and also constantly try to find a balance in the tax relations.

To ensure effective management of the tax system one should analyze the extent of the state's impact on the subjects of taxation. To do this, it is necessary to abstract somewhat from the excessive detail and variety of tax forms and, to focus on the fact that social strata of the population make the greatest contribution to the tax treasury. We fully agree with this thesis, because taxpayers happen to be the generator of the tax flow, launching it with their physical, intellectual, financial, etc. efforts. Within the tax flow generation, the function of the state administration should be to encourage the taxpayers to carry out the taxable economic operations, calculate and pay taxes.

Following P. Samuelson ${ }^{42}$ we will rely on the theory of public expenditure and its relationship with the "collective consumer goods" and use the approximation method to represent graphically the ratio of the tax burden and socially useful goods provided by the state to citizens (taxpayers). It is to be said that we consciously simplified the values and calculations for greater clarity, taking into account certain objective conditions (Fig. 2).

42 Samuelson P. A. The Pure Theory of Public Expenditures. Samuelson. Review of Economics and Statistics, 1954. Vol. 36. No. 4. P. 388. 


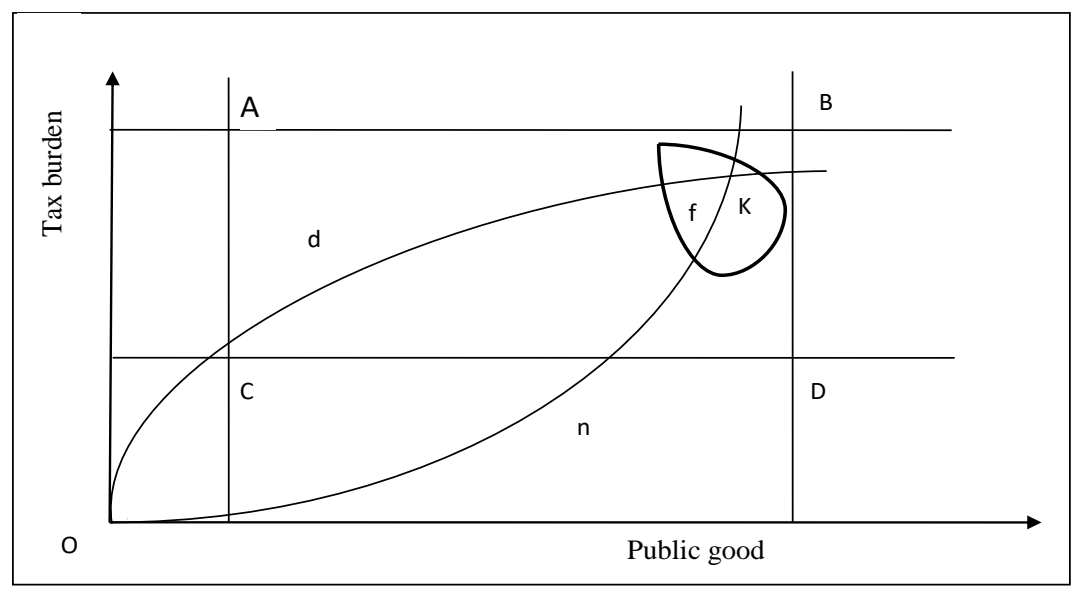

The direct $\mathrm{AB}$ corresponds to the maximum tax pressure, which increases the risk of social shifts, the expansion of the shadow economy sector, etc.

The CD corresponds to the minimum tax pressure below, within which tax revenues are not enough to cover budget expenditures.

$\mathrm{AC}$ - the level of minimum socially useful goods.

$\mathrm{BD}$ is at the level of maximum socially useful goods.

Curve $\mathrm{d}$ - tax-benefit ratio from the point of view of the state interests

Curve $\mathrm{n}$ - tax-benefit ratio from the taxpayer's point of view

Plane $\mathrm{f}$ - a correlation field of fiscal convergence, with the center at point $\mathrm{K}$, within which the level of relations "tax burden - public goods" reaches an acceptable level for all participants of the tax process

\section{Fig. 2. National fiscal convergence}

From the point of view of the public interest, the mentioned ratio corresponds to the curve $\mathrm{d}$. Of course, it is expected that the slope angle of the curve will decrease over time, as the growth of tax rates should gradually slow down (due to the risk of civil disobedience, it is impossible to raise them very quickly and indefinitely).

In addition, tax competition is an objective constraining factor of the tax rate growth, so sometimes the tax burden may have negative dynamics. The volume of socially useful goods is measured by many factors, such as the general economic development of the country, the direction of state social policy, the ratio of individual and group interests, etc. 
The volume of the socially useful goods, is a "fair share" of these interests ${ }^{43}$. This volume should gradually increase if we refer to the experience of countries with developed economies. However, this is not the case for countries whose economies are exposed to a significant impact of various crises (as is true for Ukraine): the rate of growth of this component will be somewhat slower compared to the rate of growth of the tax burden. This is particularly characteristic for the stage of elimination of the consequences of economic uncertainty, or the conditions of economic crisis, or changes in the trend of state social policy.

For taxpayers, in turn, the ratio of the tax burden to public goods will be inverse: citizens want to experience minimal tax burden and receive increasingly more public goods (curve n). However, at a certain stage of social development, taxpayers realize that in order to obtain the maximum possible benefits, to improve the standard of living as a whole, to ensure social protection, environmental safety, etc., it is necessary to pay more taxes. Therefore, with the development of public consciousness, the curve of the ratio of "tax burden to public goods" will slowly rise.

As we can see, curves $d$ and $n$ intersect twice. For the first time, at point $\mathrm{O}$, which corresponds to the pre-state period of social development, when there were no taxes or benefits. Suddenly, the curves intersect at point $\mathrm{K}$, which reflects the ideal state of development of tax relations, the hypothetical moment of complete alignment of interests of the participants of the tax process (the state and taxpayers). This moment corresponds to a highly developed society with a highly developed mentality, culture, organization, and tax system.

Yet, we are aware of the low probability of complete alignment of interests of the tax process' participants at all levels in the near future. We assume the presence of a certain correlation field (plane f)

43 Рубинштейн А. Я. К вопросу расширения «Чистой теории общественных расходов». Научный доклад. М. Институт экономики РАН. 2007. C. 16 . 
with the center at point $\mathrm{K}$, within which the level of relations "tax burden - public goods" reaches an acceptable level for all participants of the tax process.

Proceeding from this, we define the category "national fiscal convergence" as a fundamental principle of state management of the tax system of the twentieth century. It establishes the process of convergence, unification, compromise, positive complementarity and stabilization of economic and social interests of the participants of the tax process within the limits of the conditional correlation field, outlined by the ratio of public goods and tax burden.

From the point of view of regulation of tax and other social and financial relations, one of the fundamental foundations of effective state management of the tax system is the unification of the interests of all participants of the tax process (the state, economic entities, citizens), on the principles of fiscal convergence of the first level (national) with the gradual development of its second level (international), from the position of which we can talk about global tax administration.

Adaptation of the tax legislation of Ukraine to the world requirements and standards and harmonization of taxation is the main element of fiscal convergence. In order to assess the effectiveness of the functioning of the adapted tax system, it is necessary to implement certain criteria. With the use of the approximation method, it became possible to define the planes of economic interests of the state and taxpayers and conditionally determine the correlation field of their mutual interests as a desired and expected result of the development of the tax system. Proceeding from the fundamental principles of effective public administration of the tax system, it is necessary to unite the interests of all participants in the tax process (state, economic entities, citizens) on the principles of fiscal convergence of the $1 \mathrm{st}$ level (national) with its gradual development to the second level international convergence.

Based on this, we conclude that the national fiscal convergence is a process of approximation, positive complementarity, compromise, and stabilization of the interests of tax participants, 
which is implemented through the introduction of the institutional mechanism of the tax system in order to maximize the possibilities of the budget filling and the receipt of socially beneficial benefits by citizens.

\section{CONCLUSIONS}

Based on the abovesaid we are making the following conclusions:

Taxes act both as a method and as a source of state revenues, they are the result of a long historical and economic development of society, therefore the category of "tax" holds economic, philosophical and institutional meaning. The specific nature of taxes lies in the fact that the equivalent, reverse nature of tax relations is not a single act of paying a tax payment in exchange for receiving goods, but is a regular multiple procedure. The state, according to the concept of new public administration, functions as an entity.

It has been proved that the tax is a unique, institutional norm, the nature of which is multifaceted and controversial. The institutional meaning of a tax lies in its exclusive role in the process of influencing social production, and the distribution of public goods, which is carried out through taxation and allows us in a certain way to mitigate the uneven material conditions of individuals in society.

It has been found that national fiscal convergence is a process of approximation, positive complementarity, compromise, and stabilization of the interests of tax participants, implemented through the introduction of the institutional mechanism of the tax system. Its aim is to fill the budget as much as possible and obtain socially useful benefits for citizens.

In the context of globalization and international economic integration, a motivational society is emerging with a focus on the needs of the individual. Therefore, taxes as an institutional norm is an instrument for the implementation of the main priorities of the state tax policy. Those priorities are: 
- firstly, the financial aspect, according to which tax policy should provide the need for all levels of government in financial resources sufficient to implement economic and social policies and to fulfill the functions assigned to them by the authorities;

- secondly, the economic aspect, which provides the possibility of achieving sustainable economic development of the country, regions, municipalities, individual business entities. Achieving this priority is possible provided the philosophy of fiscal convergence is introduced;

- thirdly, the social aspect, which makes it possible to mitigate the inequalities in incomes arising in the process of market relations. This allows achieving the proper safety and quality of life of citizens.

\section{SUMMARY}

The article analyzes the institutional nature of tax in the contest of the concept of a new public administration and defines national fiscal convergence as a philosophy of modern tax relations.

It has been proved that taxes act both as a method and as a source of state revenue, they are the result of a long historical and economic development of society. The category "tax" holds economic, philosophical and institutional content. The tax is a unique, institutional norm, the nature of which is multifaceted and controversial. It has been proved that the institutional essence of the tax lies in its exclusive role in the process of influencing social production, and the distribution of public goods, which is carried out through taxation and allows in a certain way to mitigate the uneven material conditions of individuals in society.

It has been found that national fiscal convergence is a process of approximation, positive complementarity, compromise, and stabilization of the interests of tax participants, implemented through the introduction of the institutional mechanism of the tax system. Its aim is to fill the budget as much as possible and obtain socially useful benefits for citizens. 


\section{REFERENCES}

1. Платон Государство. пер. с древнегреческ. Собр. соч. $в$ 4-x m. М. : Мысль, 1994. Т. 3. С. 57-64. (Серия «Философское наследие»).

2. Словник економічної афористики / уклад.: А. Г. Загородній, Г. Л. Вознюк. - Львів: Видавництво Львівської політехніки, 2013. С. 257.

3. Якушик I. Д. Податки в країнах світу: довідник. К.: Леся, 2004. 479 с.

4. Монтексьє Ш. Избранные произведения в 2-томах; под. ред. М. П. Баскина. М. : гос. Изд-во Полиграфической литературы, 1955. 799 с.

5. Маркс К., Енгельс Ф. Соч. 1987. 2 изд. Т. 4. С. 710.

6. Смит А. Исследование о природе и причинах богатства народов. Антология экономической классики : в 2-х т. М. : Эконов, 1993. Т. 1. 382 с.

7. Stieglitz Joseph E. Economics of the public sector. New York / London : W. W. Norton\& company. 2000. URL: http://www.ebay.com/ctg/economics-public-sector-joseph-e-stiglitz2000-hardcover-subsequent-edition-/118991.

8. Андрущенко В. Л. Морально-етичні імперативи податків та оподаткування (західна традиція). Монографія. К.: Алерта. 2013. 214 с.

9. Алексеенко М. М. Взгляд на развитие учения о налоге у экономистов А. Смита, Ж.-Б. Сея, Риккардо, Сисмонди и Д. Миля. Москва. Издательская групnа URSS, Изд. 2. Серия: Классика политэкономической мысли. 2012. 152 с.

10. Сисмонди Симонд де Жан-Шарль-Леонард. Новые начала политической экономии или о богатстве в его отношении к народонаселению. Москва. Госиздат, 1937. 386 с.

11. Ярошенко Ф. О., Павленко В. В., Павленко В. П. Історія податків та оподаткування в Україні. Навч. посіб. за заг. ред. А. М. Подоляки. К.: ДП «Вид. дім» Персонал2. 2012. $416 \mathrm{c}$. 
12. Рикардо Д. Начала политической экономии и налогового обложения. Антология экономической классики в 2-x m. М. : Эконом, 1993. Т. 1. С. 397-460.

13. Суторміна В. М., Федосов В. М., Андрущенко В. Л. Держава - податки - бізнес (зі світового досвіду фіскального регулювання ринкової економіки). Монографія. К. : Либідь, 1992. $328 \mathrm{c}$.

14. Пушкарева В. М. История финансовой мысли и политики налогов. М. Финансы и статистика, 2001. 256 с.

15. Кулишер И. М. Очерки финансовой науки. Вып. 1. Петроград: Книгоиздительство «Наука и школа». 1919. $215 \mathrm{c}$.

16. Літвіненко Я. Податкова політика. Навч. посіб. К. МАУП, 2003. 224 с.

17. Опарін В. Фінансова система України (теоретикометодологічні аспекти). Монографія. К. : КНЕУ. 2005. 240 с.

18. Налогообложение: теории, проблемы, решения. Монографія / В. П. Вишневский, А. С. Веткин, Е. Н. Вишневская и др.; под. общ. ред. В. П. Вишневского. Донецк: ДонНТУ, ИЭП НАН Украины, 2006. 504 с.

19. Василик О. Д. Податкова система України. Навч. посіб. К. : Поліграфкнига, 2004. 447 с.

20. Селигман Э., Стурм Р. Этюды по теории обложения: пер. студентов В. Гефдинга и Б. Никольского. Под. ред. и с предисловием проф. М. И. Фридмана. СПб. 1908. 231 с.

21. Павлюченков С.А. Орден меченосцев. Партия и власть после революции. 1917-1929. Монография. Собрание, 2008. $464 \mathrm{c}$.

22. Нитти Ф. Основны начала финансовой науки: Перевод съ итальянского И. Шрейдера ; под редакцией и съ дополнениями A. Свирщевского. М. : Издание М. ис, Сабашниковыхъ, 1904. $623 \mathrm{c}$.

23. Буковецкий А. И., Гензель П. П., Кулишер И. М., Твердохлебов В. Н. Налоги в иностранных государствах. М. : Финансовое издательство НКФ СССР. 1926. 312 с. 
24. Исаев А. А. Очерк теории и политики налогов. М. ООО «ЮрИнформ - Пресс». 2004. 270 с.

25. Буряковский В. В., Кармазин В. А., Каламбет С. В. Налоги. Учебное пособие. Днепропетровск : Пороги, 1998. $611 \mathrm{c}$.

26. Пансков В. Г. Российские налоги. Нужна научная основа. Российский экономический журнал. 1993. № 3. C. 12 .

27. Горицкая Н. Подоходный налог с граждан: будущее в прошедшем. Налоговое право. № 5. 1999. С. 21-24.

28. Musgrave R. A. The Voluntary Exchange Theory of Public Economy. Quarterly Journal of Economics. 1939. Vol. 53. P. 213-237.

29. Вишневский В. П., Веткин А. С., Чекина В. Д., Виецкая О. В., Вишневская Е. Н. Формирование и реализация налоговой политики в сфере управления развитием промышленности. Монография. НАН Украины, Ин-т экономики пром-сти. Донецк, 2014. $147 \mathrm{c}$.

30. Андрущенко В. Л. Фінансова думка Заходу в $\mathrm{XX}$ столітті (Теоретична концептуалізація і наукова проблематика державних фінансів). Львів : Каменяр, 2000. 303 с.

31. Соколовська А. М. Податкова система України: теорія та практика становлення. Монографія. К. НДФІ, 2001. $372 \mathrm{c}$.

32. Юлдашев О. Ще раз про методологію удосконалення державного управління: може, востаннє? Юридичний журнал. 2005. № 9. URL: http://www.justinian.com.ua/article.php?id=1894.

33. Крушельницька Т. А Теоретична сутність і практичне наповнення податкового потоку як об'єкту державного управління. Державне управління: удосконалення та розвиток: електронне наукове фахове видання. Київ. 2015. №3. URL: http://www.dy.nayka.com.ua/.

34. Samuelson P. A. The Pure Theory of Public Expenditures. Samuelson. Review of Economics and Statistics, 1954. Vol. 36. No. 4. P. 387-389. 
35. Рубинштейн А. Я. К вопросу расширения «Чистой теории общественных расходов». Научный доклад. М. Институт экономики РАН. 2007. 55 с.

Information about the author:

Krushelnytska Taisiia,

Doctor of Public Administration, Associate Professor, Professor at the Department Economy and Regional Economic Policy, Dnipropetrovsk Regional Institute of Public Administration, National Academy of Public Administration of the President Ukraine 29, Gogolia str., Dnipro, 49044, Ukraine 
Publishing house "Liha-Pres"

9 Kastelivka str., Lviv, 79012, Ukraine

44 Lubicka str., Toruń, 87-100, Poland

Printed by the publishing house "Liha-Pres"

Passed for printing: November 25, 2019.

A run of 150 copies. 